\title{
WestVirginiaUniversity
}

THE RESEARCH REPOSITORY @ WVU

Graduate Theses, Dissertations, and Problem Reports

2016

\section{The life and legacy of MieczysLaw Munz}

\section{Sora Lee}

Follow this and additional works at: https://researchrepository.wvu.edu/etd

\section{Recommended Citation}

Lee, Sora, "The life and legacy of MieczysLaw Munz" (2016). Graduate Theses, Dissertations, and Problem Reports. 6050.

https://researchrepository.wvu.edu/etd/6050

This Dissertation is protected by copyright and/or related rights. It has been brought to you by the The Research Repository @ WVU with permission from the rights-holder(s). You are free to use this Dissertation in any way that is permitted by the copyright and related rights legislation that applies to your use. For other uses you must obtain permission from the rights-holder(s) directly, unless additional rights are indicated by a Creative Commons license in the record and/ or on the work itself. This Dissertation has been accepted for inclusion in WVU Graduate Theses, Dissertations, and Problem Reports collection by an authorized administrator of The Research Repository @ WVU.

For more information, please contact researchrepository@mail.wvu.edu. 
THE LIFE AND LEGACY OF MIECZYSLAW MUNZ

Sora Lee

\author{
A Doctoral Research Project submitted to the \\ College of Creative Arts \\ at \\ West Virginia University \\ in partial fulfillment of the requirements for the degree of \\ Doctor of Musical Arts \\ in \\ Collaborative Piano
}

\author{
Lucy Mauro, DMA, Chair and Research Advisor \\ Peter Amstutz, DMA \\ William Haller, DMA \\ Mikylah McTeer, DMA \\ Clement Solomon, PhD
}

\author{
School of Music
}

\title{
Morgantown, West Virginia 2016
}

Keywords: Mieczyslaw Munz, Polish pianist, Munz, Polish-American pianist, $20^{\text {th }}$ century pianists, Historic concert pianists 


\section{ABSTRACT \\ THE LIFE AND LEGACY OF MIECZYSLAW MUNZ}

Sora Lee

Mieczyslaw Munz (1900-1976) was one of the outstanding pianists of the twentieth century as both an acclaimed international concert artist and teacher. With a musical career that spanned over sixty years from his debut at the age of twelve, Munz was a significant link in carrying on the great traditions of the Golden Age of the Virtuoso and nineteenth-century piano playing. This research paper includes a biography of Munz; interviews with his students Faye Bonner, Paula Forrest, Jeffrey Marcus, David Oei, Ann Schein, Robert Swan and Stefan Young; a timeline of important events in the life of Munz; selections of Munz's concert programs, reviews, and other memorabilia; and a list of recordings by Munz. 


\section{ACKNOWLEDGMENTS}

I would like to express my deepest gratitude to my dissertation advisor, mentor and teacher, Dr. Lucy Mauro, who helped me through six years of study from my Master's degree to this moment. Without her devotion and assistance, not only on this dissertation, but also my entire graduate study, I would be not be able to reach this point. I would also like to thank my committee members for their helpful thoughts and suggestions. This research would not be possible without the interviews and communications with Munz's students. My sincerest thanks go to Miss Ann Schein, Mrs. Faye Bonner, Ms. Paula Forrest, Mr. Jeffrey Marcus, Mr. David Oei, Dr. Robert Swan, and Dr. Stefan Young. I also extend my sincere gratitude for their assistance with this research to Mr. Donald Manildi at the International Piano Archives at the University of Maryland, Mrs. Helene Van Rossum at The Curtis Institute of Music Archives, Mrs. Lee Ann Tuason at The Juilliard School, Mr. Paul Cauthen at University of Cincinnati, Mrs. Jennifer Ottervik at The Peabody Institute of Music, and Ms. Jessie Amaolo at the Toronto Reference Library. Lastly, I would like to especially thank my husband and children for their support and sacrifice through my doctoral degree.

Sora Lee

April 2016 


\section{TABLE OF CONTENTS}

LIST OF FIGURES

CHAPTER

I. BIOGRAPHY OF MIECZYSLAW MUNZ (1900-1976) ………………………........... 1

II. INTERVIEWS WITH STUDENTS OF MIECZYSLAW MUNZ ................................ 26

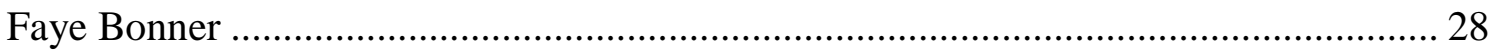

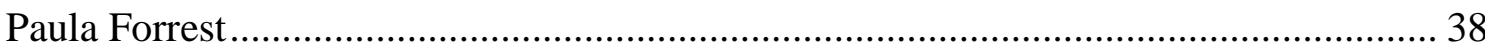

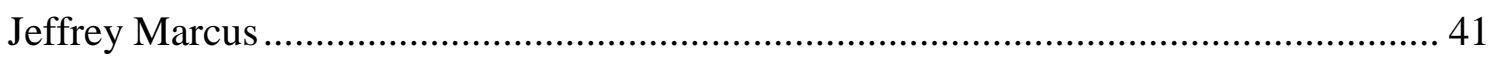

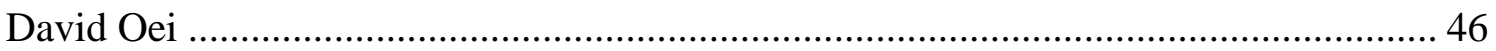

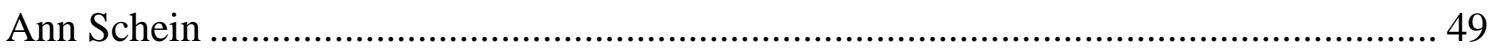

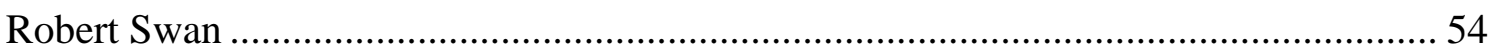

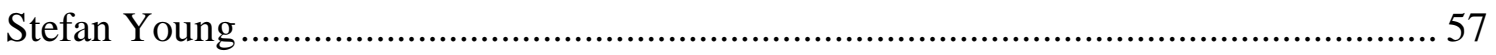

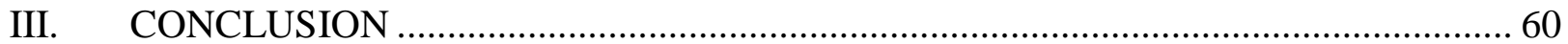

APPENDIX A: TIMELINE OF EVENTS IN THE LIFE OF MIECZYSLAW MUNZ ............. 63

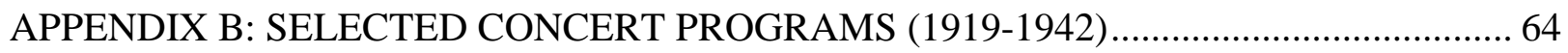

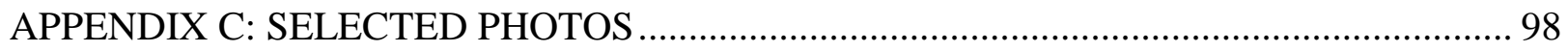

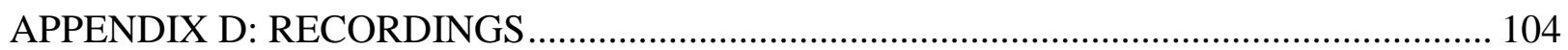

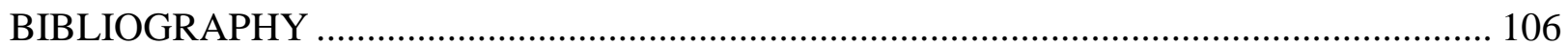




\section{LIST OF FIGURES}

Figure 1 The program of Munz's debut in New York, Aeolian Hall, 1922.................4

Figure 2 Advertisement in The Musical Monitor, 1922..............................5

Figure 3 Program of recital in Aeolian Hall, 1922...............................6

Figure 4 Program of recital in Canada, University of Toronto Arena, 1940..............16

Figure 5 Minuet from “Berenice” published by G. Schirmer, Inc., 1940.................18

Figure $6 \quad$ Group photo taken in Korea in June 29, 1967............................24

Figure $7 \quad$ Photo of the telegram Rubinstein sent to Munz.............................37 


\title{
CHAPTER I
}

\section{BIOGRAPHY OF MIECZYSLAW MUNZ (1900-1976)}

\author{
By many critics he has been acclaimed the Heifetz of the piano. ${ }^{1}$
}

Mieczyslaw Munz (1900-1976) was one of the outstanding pianists of the last century as both an acclaimed international concert artist and teacher. With a musical career that spanned over sixty years from his debut at the age of twelve, Munz was an important representative of what many consider to be the "Golden Age of the Virtuoso"2 and a significant link in carrying on the great traditions of $19^{\text {th }}$-century piano playing. As a concert pianist, he toured throughout Europe, North and South America, Australia, and Asia until the early1940s when his performing career was abruptly ended by a problem with his hand and arm, a condition likely made worse by a number of personal tragedies he endured. Though ending his concert career, Munz went on to hold several important teaching positions at the Cincinnati Conservatory of Music in Ohio, The Curtis Institute of Music in Philadelphia, The Juilliard School in New York, The Peabody Institute of Music in Baltimore and the Manhattan School of Music in New York. He became a distinguished and beloved teacher, with many of his students becoming revered concert artists and teachers themselves.

Mieczyslaw Munz ${ }^{3}$ was born in Krakow, Poland on October 31, 1900. Little is known about his childhood and family other than his father was a jurist and he had an older brother

\footnotetext{
${ }^{1}$ Program notes of Mieczyslaw Munz Season at Town Hall, Melbourne,1924

2 The Golden Age of the Virtuoso for pianists is generally regarded as the late $19^{\text {th }}$ through early $20^{\text {th }}$ centuries, and is a description found in recordings (see pianist Earl Wild) and in literature, notably in journal articles and interviews.

${ }^{3}$ The original spelling of Munz's last name was Münz. In later years, the "ü" was replaced with " $u$ ".
} 
“who couldn’t play piano at all.”4 Munz’s musical talent appeared early as he reportedly played folk songs of his native Poland on the piano by ear at the age of three. ${ }^{5}$ Munz entered the Krakow Conservatory at the age of nine studying with Georg von Lalewicz (1877-1951). Lalewicz was born in Wylkowyszki, Poland and went to St. Petersburg, Russia in 1894 where he studied piano with Annette Essipoff (1851-1914) and composition with Anatoly Liadov (18551914) and Nikolai Rimsky-Korsakov (1844-1908). Lalewicz's teacher Essipoff was one of the outstanding students (and later second wife) of the renowned Polish pianist and teacher Theodor Leschetizky (1830-1915) who himself was a student of Carl Czerny who taught Liszt. In 1900, Lalewicz won the first prize in the Rubinstein competition in Vienna and later became a professor at the Royal and Imperial Academy in Vienna. ${ }^{6}$ From his earliest studies with Lalewicz, Munz received training instilling him with legendary pianistic tradition.

Munz made his debut in Krakow at the age of twelve, playing Tchaikovsky’s Piano Concerto No. 1 with the Krakow Symphony Orchestra. When he was fourteen years old, Munz moved to Vienna, where he spent his teenage years and where he studied with Lalewicz at the Academy. During that time, he also served a brief period in the military. ${ }^{7}$ In 1919, Munz moved to Berlin where he studied at the Hochschule für Musik under Ferruccio Busoni (1866-1924). Busoni was an Italian composer, pianist and teacher. He is known today mostly for his transcriptions and the international piano competition named after him in Italy. Busoni's teaching legacy included such as Kurt Weill, Edgard Varèse, Percy Grainger, Egon Petri and

\footnotetext{
${ }^{4}$ Munz's papers, Cincinnati Conservatory, 1925.

${ }^{5}$ Program notes of Mieczyslaw Munz Season at Town Hall. Melbourne,1924

${ }^{6}$ Cesar Saerchinger, International Who's Who in Music and Musical Gazetteer: A Contemporary Biographical Dictionary. (New York: Current Literature Publishing Company, 1918), 353.

7 International Piano Archives at University of Maryland. "Mieczyslaw Munz Collection" http://www.lib.umd.edu/ipam/collections/mieczyslaw-muns (accessed February 26, 2016)
} 
more. ${ }^{8}$ Munz became Busoni's assistant and through that exposure, at such a young age, he began what would soon become an illustrious teaching career.

Munz made his formal pianistic debut in Berlin in 1920 playing what must have been a sensational concert. He performed three concertos: the Piano Concerto No. 1 in A Major by Liszt, the Piano Concerto No. 1 in D Minor by Brahms, and the Symphonic Variations by Franck with the Berlin Symphony Orchestra. ${ }^{9}$ Following his debut, Munz performed in Vienna and Rome and toured throughout Poland and Hungary.

After his European success, Munz made his New York debut on October 20, 1922 in Aeolian Hall. (Figure 1)

\footnotetext{
${ }^{8}$ The Famous People. "Ferrucio Busoni Biography" http://www.thefamouspeople.com/profiles/ferruccio-busoni324.php (accessed April 11, 2016)

9 International Piano Archives at University of Maryland. "Mieczyslaw Munz Collection" http://www.lib.umd.edu/ipam/collections/mieczyslaw-muns (accessed February 26, 2016)
} 


\section{AEOLIAN HALL 34 West 43 rd St. Now York \\ FRIDAY EVENING \\ OCTOBER 20th \\ at 8:15 o'clock \\ PIANORECITAL \\ by \\ MIECZYSLAW \\ M Ü N $\mathbf{Z}$}

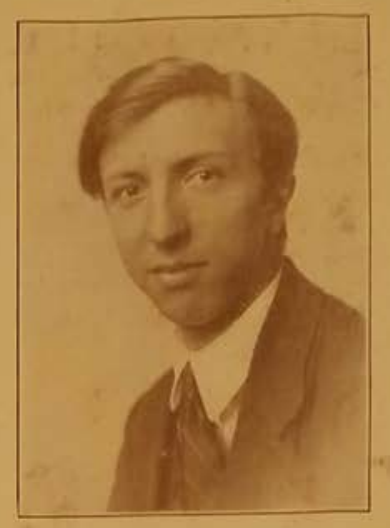

fingraume:

I.

Variations on a Theme, and Choral from the Cantata

"Weinen.Klagen.Sorgen-Zagen" [arr. by Liszt]

Menuet [first time]

II.

Bach Bach

Prelude-Aria-Finale

Doctor Gradus ad Parnassum

César Franck

Prelude G sharp minor

Debussy

Liebesfreud [first time]

Rachmaninoff

Kreisler-Müz

III.

Etude, Op. 10
No. $x$ in $\mathrm{C}$ major
No. 12 in $\mathrm{C}$ minor
Nocturne, $\mathrm{C}^{\text {Major }}$

Two Mazurkas

Nachtfalter

Chopin Chopin

IV.

Strauss Tausig

KNABE PIANO USED

AMPICO RECORDS

BERLIN, Deutsche Zeitung, Oct. 1921 .

Not to be forgotten was the Symphony concert of Richard Strauss and of young M. Mün VIENNA, Weltblatt, 2Nov, 192

Virtuosity, temperament and profound musicianship enraptured his audience.

ROME, Il Tempo, Oct. 192t.

He disposes over a perfect technique, noble interpretation and temperament

WARSAW, Evening Post, Feb, tgzo.

M. Müz, no doubt still young, but in music a ripe artist, is already now the successor of

Rubinstein, Hoffmann and Friedman.

Figure 1. The program of Munz’s debut in New York, Aeolian Hall in 1922.

Munz's performance gained praise by both the critics and the public. The New York Journal wrote: "The pianist soon had the audience bending forward in their chairs and losing 
themselves in his playing. He is quite young, but indubitably gifted.” 10 The New-York Tribune said, "Pianoforte playing of a higher order than that disclosed at Aeolian Hall last night will probably be heard at some, but not many, recitals and concerts this season." ${ }^{11}$ The same paper also described his "warmth of feeling and admirable technique." 12 Other descriptions of his artistry included “a delicately-minded player with daredevil fingers” and "beautifully musical in tone” with “delightful delicacy and precision.”13 (Figure 2)

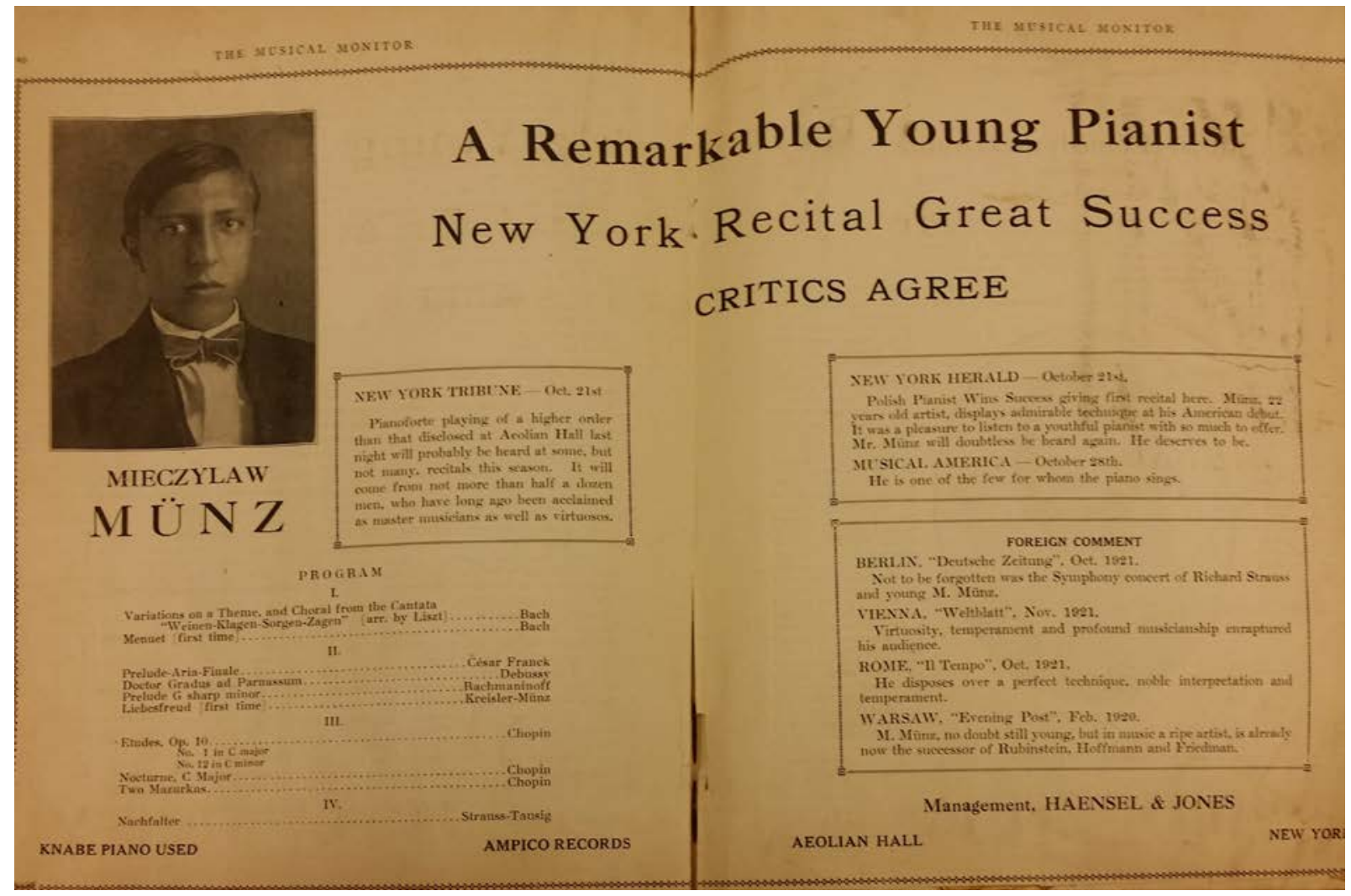

Figure 2. Advertisement in The Musical Monitor in 1922.

\footnotetext{
${ }^{10}$ New York Journal, October 21, 1922.

${ }^{11}$ H.E. Krehbiel, New-York Tribune. October, 21. 1922.

${ }_{12}$ Musical Courier, November 23, 1922.

${ }^{13}$ Emanuel Ax and Ann Schein. "Remembering Mieczyslaw Munz with Emanuel Ax and Ann Schein" Virtuoso 1, no. 71 (1980): 14-16.
} 
Soon after his debut, Munz gave a second recital in New York. (Figure 3)

\section{AEOLIAN HALL 34 West 43rd St. New York City \\ THURSDAY EVENING DECEMBER 7th \\ at $8: 15$ o'clock}

SECOND PIANO RECITAL b y MIECZYSLAW

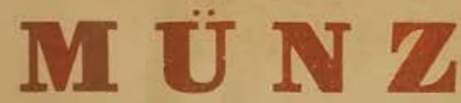

\section{jignganme:}

I.

Sonate, Op. 5, F minor Allegro maestoso Andante: "Motto"

$$
\begin{aligned}
& \text { Der Abend dimmert, } \\
& \text { Das Mondlicht scheint, } \\
& \text { Da sind zwei Herzen } \\
& \text { In Liebe vereint } \\
& \text { Und halten sich selig umfangen. }
\end{aligned}
$$

Scherzo

Finale

II.

iil.

La Cathédrale engloutie

La fille aux cheveux de lin

Movements perpetuels

Tabatiere a musique

Mazurka, A minor

Polonaise, A flat major

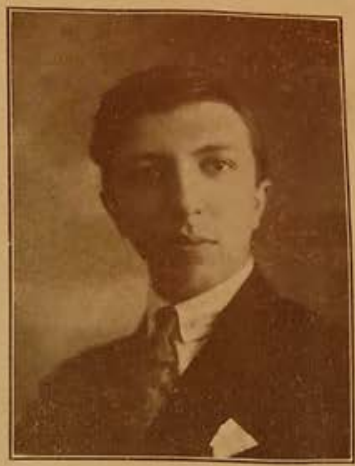

KNABE PPIANO USED

Nese York Tribune, Oct. 22nd, 1922

"Pianoforte playing of a higher order than that disclosed at Aeolian Hall last night will probably be heard at some, but not many, recitals and concerts thi night will probably be hea
season.". H. E. Krehbiel.

New York Herald, Oct. 22nd, 1922.

He compelled a brilliant and fluent technic to serve his artistic purposes. He revealed a fine feeling for the lyric qualities of his music and showed that he possessed in no small measure the power to make the piano sing."- IV. J. Henderson. New York Sun, Oct, 22nd, 1922

He played so brilliantly to so many enthusiasts the occasion rose to reall. triumphant levels. Few surprises like this reward the diligence of professional concertgoers." - Gilbert Gabriel.

Figure 3. Program of recital in Aeolian Hall, 1922. 
After Munz’s initial success, he did a second tour in 1923 in America, beginning in Carnegie Hall and followed by orchestral appearances in New York, St. Louis, Kansas City, and Minneapolis, among others, and recitals in Chicago, Boston and New York at the Metropolitan Opera House. In November 1924, he completed a tour of over eighty concerts in Australia, China and Japan. Philip Hale of the Boston Herald said: "He is already a pianist who commands respect; a virtuoso who is also musical. He can thunder and lighten when the music calls for tempestuous performance. He is also a master of tonal gradations and nuances. Respectful towards composers, respecting his art, he makes no deliberate appeal to an audience." ${ }^{14}$ Herman Devries of the Chicago Evening American said: "praise cannot do justice to the remarkable performance of yesterday afternoon, to the variety and extraordinary pertinence of his prismatic tone coloring...glittering clarity of his technical execution, to the felicitous play of light and shade and mood illuminating his interpretation to the modesty and simplicity of his personality." 15 This young virtuoso began an impressive concert career that would last some twenty years touring throughout Europe, North and South America, the Far East, and Australia. In the United States, he would go on to perform with the orchestras of New York, Boston, Cincinnati, Philadelphia, and many other cities, collaborating with conductors such as Fritz Reiner, Serge Koussevitzky, Victor de Sabata, Walter Damrosch, Willem Mengelberg, and Ossip Gabrilowitsch. $^{16}$

The success in Europe, Asia, and America made this young Polish pianist famous in his country, and his success influenced many Polish musicians to dream about a career in America. One such person was Wiktor Labunski (1895-1974). Labunski was a composer, pianist and

\footnotetext{
${ }^{14}$ Publicity materials, personal file of Munz, Cincinnati Conservatory

15 Ibid.

${ }^{16}$ International Piano Archives at University of Maryland. "Mieczyslaw Munz Collection" http://www.lib.umd.edu/ipam/collections/mieczyslaw-muns (accessed February 26, 2016)
} 
conductor, and a friend of Munz. Labunski's wife was Wanda Mlynarski, who was a sister of Nela Mlynarski, who later was married to Munz. Labunski recollected that Munz had “exceptional talent and personal charm” and that Munz “went to America with a very modest sum of money ... Good luck was with him - within one season he made a name for himself on the so-called 'big circuit.' The return to Krakow of the local boy who made good was a triumph, he was feted and wined and dined."17 Labunski also said Munz "never forgot that we were his friends even before he had had his first successes in Vienna, and during summer time he often visited us, or invited us to parties at his home... It so happened that Wanda's sister Nela visited us from time to time, and became acquainted with Munz." ${ }^{18}$ Labunski may have played a critical role in introducing Nela and Munz, and in their marriage as well.

Munz’s relationship with Labunski represents an important example of Munz’s generous character. Wiktor Labunski was born in St. Petersburg, Russia, and was a student of Felix Blumenfeld at the St. Petersburg Conservatory (Blumenfeld is known as the great teacher of Vladimir Horowitz). ${ }^{19}$ In 1918, Labunski moved to Krakow, Poland, and started to teach at the Krakow Conservatory from 1919 to $1928 .^{20}$ During this time, Labunski was influenced and encouraged by Munz and his success in America, as moving to America would have been very challenging but desirable to many Polish musicians at the time. Labunski decided to leave Poland for America, but travel expenses were a problem. Labunski recalled that one day, after a return trip to Poland, Munz handed Wiktor an envelope containing several hundred dollars

\footnotetext{
${ }^{17}$ Harvey Sachs, Rubinstein: A Life. (New York: Grove Press, 1995), 235.

18 Ibid, 235.

${ }^{19}$ Richard J.Belanger, "Wictor Labunski: Polish-American Musician in Kansas City, 1937-1974: Case of Study." (Ph.D. diss., Columbus University Teachers College, 1982) 7.

${ }^{20}$ Aryeh Oron, " Short Biography: Wiktor Labunski (composer, arranger), Bach-Cantata Website, http://www.bachcantatas.com/Lib/Labunski-Victor.htm (accessed March 8, 2016)
} 
saying, "This is a loan and you will pay me back when you start earning your living in dollars." 21 Munz also helped Labunski achieve his first job in America. Munz’s manager arranged an interview for a teaching position in the Nashville Conservatory in Nashville, Tennessee, for Labunski. The salary for the position was \$5,000, which was a large amount in 1928. While Wiktor waited to hear from the Nashville Conservatory, Munz also helped him to stay at the home of a friend. ${ }^{22}$ With Munz's help, Labunski settled in America and his teaching career lasted from 1928 to 1971, first at the Nashville Conservatory in Tennessee (1928-1931), later the Memphis College of Music in Tennessee (1931-1937), and lastly at the Kansas City Conservatory in Missouri (1941-1971). ${ }^{23}$

In 1925, an unexpected and memorable event happened which demonstrated Munz’s exceptional abilities as a concert artist. When Munz attended his colleague Ethel Leginska’s performance at Carnegie Hall, he had just returned to New York from a concert tour and attended the recital. However, Leginska did not show up, so Munz came onto the stage from the audience and volunteered to play all the works on her program. ${ }^{24}$ He received an enormous ovation and was recalled for many encores. The review in Musical America said, "His style is sober and sonorous, and technically is often of great deftness” and also commented on his “precision, grace and flexibility.”25

Munz’s programs show a vast recital repertoire. In 1925, his musical tastes were listed as preferring “Bach, Brahms and Franck of the classicists” and "Ravel, Busoni, Rachmaninoff,

\footnotetext{
${ }^{21}$ Richard J.Belanger, "Wictor Labunski: Polish-American Musician in Kansas City, 1937-1974: Case of Study." (Ph.D. diss., Columbus University Teachers College, 1982) 35-36. 22 Ibid.

${ }^{23}$ Aryeh Oron, " Short Biography: Wiktor Labunski (composer, arranger), Bach-Cantata Website, http://www.bachcantatas.com/Lib/Labunski-Victor.htm (accessed March 8, 2016)

${ }^{24}$ Information from Ann Schein

25 International Piano Archives at University of Maryland. "Mieczyslaw Munz Collection"

http://www.lib.umd.edu/ipam/collections/mieczyslaw-muns (accessed February 26, 2016)
} 
and Szymanowski of the moderns." ${ }^{26}$ Munz’s programs included standard masterworks such as the Fantasie in C Major of Schumann, the Preludes and selected Nocturnes of Chopin, Sonatas and Intermezzos of Brahms, Sonatas of Beethoven, and the Goldberg Variations by Bach, as well as transcriptions not only by Liszt, Busoni, Tausig, Godowsky, and Dohnanyi, but also his own. Munz performed his own transcriptions of such works as Kreisler's Liebesfreud (premiered at his New York debut) and Chopin's Waltz in Db Major. Rosemary Mookerjee, one of his American pupils, wrote in her thesis about Munz’s programming: “This contemporary taste shows the influence of Busoni, Munz's teacher, who also performed many similar programs in his own career." ${ }^{27}$ A series of recitals he performed in Japan in 1924 demonstrated not only the variety of his repertoire, but also his virtuosity. Munz performed recitals Friday through Wednesday, every night but Monday, with a different program on each night. ${ }^{28}$ Another testament to Munz's virtuosic playing is recalled in the story of Munz attending the concert of his good friend Rachmaninoff. After the concert when Munz went backstage to congratulate him, Rachmaninoff said, "Get away from here: people keep telling me that you play my Rhapsody better than I do." 29

In 1925, Munz began his teaching career in the United States at the Cincinnati Conservatory of Music, where he taught from 1925 to $1930 .{ }^{30}$ In $1928,{ }^{31}$ Munz married Aniela (Nela) Mlynarski (1908-2001), the daughter of the Polish conductor Emil Mlynarski (1870-

\footnotetext{
${ }^{26}$ Munz's papers, Cincinnati Conservatory, 1925

${ }^{27}$ Rosemary Mookerjee, "Mieczyslaw Munz: His Students and His Teaching" (M.M. thesis, The Catholic University of America, 1987) 2.

${ }^{28}$ See Appendix C, programs 22-26.

${ }^{29}$ Emmett M. Ford, “Biographical Sketches: Mieczyslaw Munz" AMICA 14, \#3 (April, 1977): 72-73.

30 Munz Begins 1925: The Polish Pianist Arrives, The Cincinnati Enquirer, October $1^{\text {st }}, 1925$.

${ }^{31}$ There is some discrepancy with the actual date. US Census records of 1930 show Aniela Munz as 19 and Mieczyslau/Mieczyslaw Munz as 27 as the ages for their first marriage; in addition, New York Passenger Lists show Aniela Munz, age 20 and Mieczyslaw Munz, age 28 entering the US in October 30, 1928. (ancestrylibrary.com accessed February 28, 2016.)
} 
1935). Nela was born on July 30, $1908^{32}$ in Vilnius, Lithuania and was trained as a ballet dancer.

Her father was one of the most prominent musicians in Poland as the founding conductor of the Warsaw Philharmonic and director of the Warsaw Opera. He was the conductor when the young Arthur Rubinstein made his debut in Poland at age 13. ${ }^{33}$ A 1983 article in The New York Times dramatically described the fateful situation surrounding Munz's marriage to Nela:

"When the pianist Arthur Rubinstein met Aniela Mlynarska in Warsaw in 1926 he described the meeting as a "coup de foudre" - a thunderbolt. Rubinstein was nearly 40 years old and Nela (a diminutive of her name, which means angel in Polish) was 18. She was the daughter of Emil Mlynarski, director of the Warsaw Symphony, and had come backstage during a Rubinstein concert. In his autobiography the pianist gave a lyrical description of her at their meeting: "a small, fine face with the bluest eyes, like turquoise" and "a mass of dark blond hair." He said he knew she was the only woman he wanted to marry, although six years would pass before he did ... Yes, it was love at first sight for both of them, Arthur Rubinstein's widow agrees. But he had misgivings. There had been - and still were, even at the time of the fateful meeting - many women in his life; being a lover was different from being a husband. "He was afraid of marriage," Mrs. Rubinstein recalls. "He knew so many unfaithful wives."

Although he proposed the next day, he left Warsaw for a concert tour and she did not hear from him; he expected her to write first. "But," she said, "I wasn't brought up that way - the man was to write first." He returned to Warsaw and proposed for a second time, and again, "He went off and I began to think it was all a dream." 34

Unlike Rubinstein, who hesitated in committing himself to Nela, Munz was more than ready to give his commitment to her. Nela even told Rubinstein about Munz: "There is a young pianist, Mieczyslaw Munz, who wants to marry me. He is terribly in love with me. He sends me flowers and letters. I told him that I was in love with you but I admitted that I do not believe you mean to marry me." 35 Also she recalled: "I wrote to Münz then that I was not ready yet, that I

\footnotetext{
32 http://www.sejm-wielki.pl/b/psb.18596.11 (accessed February 28, 2016)

${ }^{33}$ Wolfgang Saxon, "Aniela Rubinstein, 93, Widow of Pianist and Patron of the Arts", The New York Times, January 5, 2002.

${ }^{34}$ Angela Taylor, "Nela Rubinstein: Making a Life of Her Own", The New York Times, December 12, 1983.

${ }^{35}$ Harvey Sachs, Rubinstein: A Life. (New York: Grove Press, 1995), 236.
} 
had seen Rubinstein and he had made such a confession, and in any case I was not finished with it. So Münz immediately dropped his whole tour in the United States and arrived in Warsaw a week or so later to be near me. And then nothing happened from Arthur, still! He went Buenos Aires to make money.” ${ }^{36}$ Munz's dedication to Nela was shown when Labunski described “a spectacular courtship, which included flowers by telegraph from New York, San Francisco, and Yokohama...Some of the close and distant [Mlynarski] relatives had their objections to Nela marrying a Jew. To the immediate family this fact was of no concern, however in order for the couple to marry, one or the other had to convert, and Munz was the one who did it.”37

Nela finally accepted Munz's proposal and they married and moved to America. The United States Census Records from 1930 show that Munz and Nela had resided as boarders at the residence of Dr. Karol Lizniewski (1876-1958) and Marguerite Liszniewska (1879-1935) at 664 Crown Street in Cincinnati where Munz was teaching at the Conservatory. The Lizniewskis were pianists and teachers at the Conservatory also, and they hosted many international musicians in their home. In 1929, Emil Mlynarski, Nela’s father, moved to America to become a professor of conducting at The Curtis Institute of Music in Philadelphia. He stayed at Curtis until 1931. Nela visited her father, and it seemed she spent more time there and traveling than with her husband in Cincinnati. ${ }^{38}$

In 1930, Munz's fellow countryman and friend Josef Hofmann, invited him to join the faculty of The Curtis Institute of Music. ${ }^{39}$ Munz may have accepted the opportunity gladly for Nela so that she could be near her parents. In that same year, he also began teaching at The Peabody Institute of Music in Baltimore, with a few selected students. It must have been a happy

\footnotetext{
36 Ibid, 236.

${ }^{37}$ Harvey Sachs, Rubinstein: A Life. (New York: Grove Press, 1995), 238.

${ }^{38}$ Arthur Rubinstein, My Many Years. (New York: Alfred A. Knopf, 1980), 288.

${ }^{39}$ Brochure from The Mieczyslaw Munz Scholarship Fund, Inc.
} 
time for Munz with a successful performing career, teaching positions, and a new married life. However, in 1931 Emil Mlynarski returned to Warsaw from Philadelphia due to illness, as he was afflicted with a severe arthritis. ${ }^{40}$ Nela followed her parents to Warsaw, leaving Munz alone in America. There she met Rubinstein again at a concert of Gregor Piatigorsky. They soon began to spend time together. In the biography of Rubinstein by Harvey Saches, Nela said, "It was not simple, and I was still married. But then we discussed that I was going to divorce. Munz's father was a dear old lawyer who arranged it all painlessly.... I had to change religion in order to get a divorce, because Catholics couldn't," ${ }^{41}$ which is ironic as Munz had to become Catholic to marry Nela. ${ }^{42}$ However, Munz accepted this devastating situation, and Rubinstein said, “Münz behaved in the most noble way; in spite of the deep unhappiness he felt about losing her, he did all in his power to give her freedom.” ${ }^{43}$ In 1932, Nela received her divorce certificate and became Nela Rubinstein in July of that same year.

With the loss of Nela and also unfortunately his position at The Curtis Institute of Music in 1932, Munz entered into a period in his life of great difficulties, both financially and personally. A 1933 letter dated May 22 by Munz to Mrs. Mary Louise Curtis Bok (who was the founder of The Curtis Institute of Music) showed his miserable situation: "I managed to see myself and my parents through this winter but could not save anything besides ... And now I am left all alone, with no one to help me or my family and my next chance of doing something is South America in 1934.” ${ }^{44}$ In 1933, Munz's teaching at Peabody also ended. ${ }^{45}$ He continued his

\footnotetext{
${ }^{40}$ Arthur Rubinstein, My Many Years (New York: Alfred A. Knopf, 1980), 304.

${ }^{41}$ Harvey Saches, Rubinstein: A Life (New York: Grove Press, 1995), 241.

42 Ibid, 238.

${ }^{43}$ Arthur Rubinstein, My Many Years (New York: Alfred A. Knopf, 1980), 318.

${ }^{44}$ Miecsyslaw Munz to Mary Louise Curtis Bok, letter, May 22, 1933.

${ }^{45}$ Peabody Archives Records
} 
performing career, with a Town Hall recital in 1938 in New York as a particular standout performance $^{46}$, though little documentation can be found.

In September 1939, Germany invaded Poland where Munz’s family lived. He expressed his deep sadness and distress in the letter to Mrs. Bok in October 1939: "My heart and soul is with my country, with my old and helpless parents, I did not hear from ever since the war broke out. God be with them and help me to get them out of German oppression. Under such circumstances, I feel that whatever I make this season, must be kept intact, as emergency fund for them." ${ }^{47}$ Two months later in another letter, he wrote, "Having returned to New York I found a very distressed letter from my family in Krakow...the only thing for me to do now is to try and get them out. It will require superhuman efforts on my part, but I shall be happy to make every sacrifice." ${ }^{48}$ The great pianist Josef Hofmann was one of Munz's best friends, who helped him financially. The letter Josef Hofmann sent to the highly influential Samuel Chotzinoff (music critic and music director at NBC) in 1939 shows the sadness he felt about Munz's difficult financial situation:

Dear Chotzie: I feel that you would find Munz musically and personally very worthwhile, and considering his Radio experience - perhaps you might be able to help him back on his feet again. Please let me know if I am asking too much. I can't help making this request because it makes my heart bleed to see a fellow artist as gifted as he is bearing in actual financial need. Is ever yours, Josef Hofmann. ${ }^{49}$

Josef Hofmann also recommended Munz to Columbia Artists Management to give a concert at Carnegie Hall as a replacement of his own concert. Walter Hautzig, who was a pupil

\footnotetext{
${ }^{46}$ Emmett M. Ford, "Biographical Sketches: Mieczyslaw Munz" AMICA 14, \#3 (April, 1977): 73.

${ }^{47}$ Munz to Bok, letter, October 26, 1939.

${ }^{48}$ Munz to Bok, letter, December 23, 1939.

${ }^{49}$ Rosemary Mookerjee, "Mieczyslaw Munz: His students and his teaching"

(M. M. thesis, The Catholic University of America, 1987) 5.
} 
of Munz, kept the letter from Hofmann to Columbia Artists Management. In the letter, Hofmann stated that it was only Munz who could adequately fulfill his commitment. ${ }^{50}$

Another important person in Munz’s life was Reginald Stewart (1900-1984), the Scottish born conductor, pianist and teacher who was very active in America and Canada. Stewart was born in Edinburgh and studied with H.T. Collinson who was a choir master at St. Mary’s Cathedral, Arthur Friedheim and Mark Hambourg in Toronto, and Nadia Boulanger and Isidor Phillpp in Paris. He founded the Toronto Bach Choir in 1933 and also the Toronto Philharmonic Orchestra in 1934. Later he came to America and became a conductor of the Baltimore Symphony Orchestra (1942-1952) and the head of The Peabody Institute of Music (19411958). ${ }^{51}$ Reginald Stewart valued Munz’s musical gifts highly, and they performed over twenty times together in Toronto. ${ }^{52}$ The headline of the review of their concert together on July 19, 1940 at Varsity Arena in Toronto, states, “Münz is given ovation for Rhapsody: Rachmaninoff's Work, Inspired by Paganini, Exacting - Stewart’s Orchestra in Fine Form.” ${ }^{53}$ And the critics also wrote, “Reginald Stewart’s orchestra was in great form last night at Varsity Arena, and Mieczyslaw Münz-more prosaically 'Mince’-was a tremendous success in his big and brilliant piano number. The Rhapsody, written some six years ago, is arranged upon variations on a Paganini theme, has the dazzling characteristics to be anticipated from a work inspired by anything of Paganini's, is exacting to a degree, but it rippled and flashed in the sunlight of Mr. Munz' expertise with a most deceiving air of simplicity. The soloist got a great ovation for it.”54

\footnotetext{
50 Ibid.

${ }^{51}$ Reginald Stewart, https://en.wikipedia.org/wiki/Reginald_Stewart_(conductor) (accessed March 10, 2016)

52 Brochure of The Mieczyslaw Munz Scholarship Fund, Inc.

${ }^{53}$ Rose Macdonald, July 19, 1940 quoted in International Piano Archives at University of Maryland. "Mieczyslaw Munz Collection” 54 Ibid.
} 
(Figure 4).

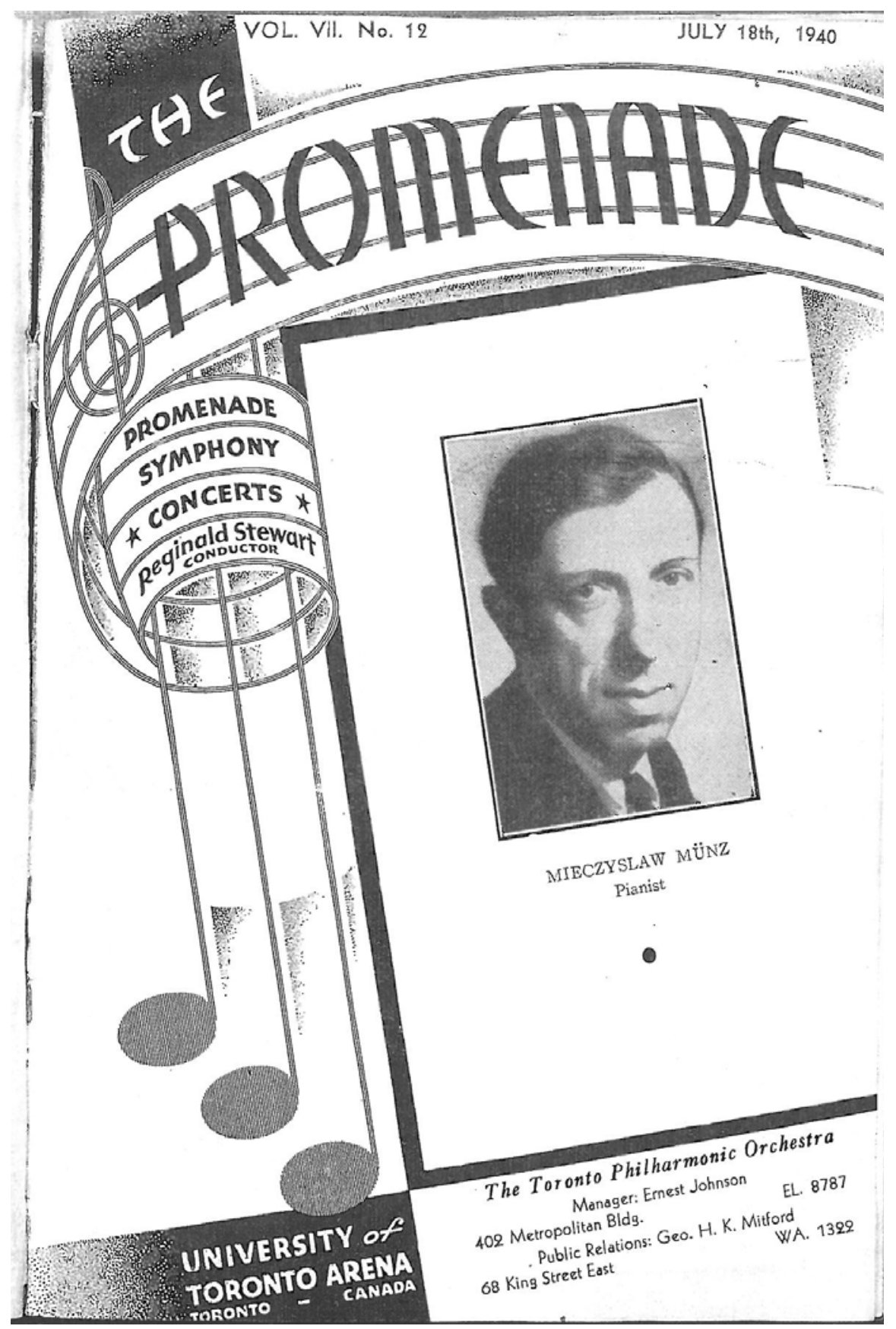

Figure 4. Program of recital in Canada, University of Toronto Arena, 1940.

The review citing the "more prosaically Mince" recalls a poem Munz once amusingly wrote to the Musical Courier in response to the pronunciation of his name: 
In spite of beseechings and hints

That plays upon words make me wince.

My friends take my name

And make puns on the same.

"Woe is me!" cried Mieczyslaw Münz. ${ }^{55}$

In 1940, Munz also had several other important performances, and G. Schirmer published one of his transcriptions. A letter sent by Munz to Mrs. Mary Curtis Bok on August 14, 1940 said, "While in Canada this summer, I discovered a beautiful tune from Handel’s opera "Berenice” and made a free transcription for piano. In all my modesty I think I have done a good job of it and will play it this season at my concerts. Yesterday it has been accepted for publication by Schirmer and will be out already in the fall. Now, my thoughts turn to you and I wish to ask your permission to show my admiration and gratitude by dedicating it to you." ${ }^{56}$ In December 1940 the music had been published. Munz wrote to Mrs. Bok: “On my way back from the White House ${ }^{57}$, where I played for the First Lady, I stopped in Philadelphia to pay my respects to the First Lady in America's music. Luck was unfortunately against me, as Miss Hutt informed me you wouldn’t be at the Institute that day. I left with her my transcription, just released by Schirmer's, which I hope in the near future to play for you if I may.”58 (Figure 5)

\footnotetext{
${ }^{55}$ Florence Times Daily, December 5, 1940.

${ }^{56}$ Mieczyslaw Munz to Mary Louise Curtis Bok, letter, August 24, 1940.

${ }^{57}$ For this concert for Mrs. Roosevelt, Munz played the Handel transcription, a Bach-Busoni chorale, Weber's Invitation to the Dance, and three pieces by Chopin.

${ }^{58}$ Munz to Bok, letter, December 10, 1940.
} 


\section{Minuet from "Berenice"}
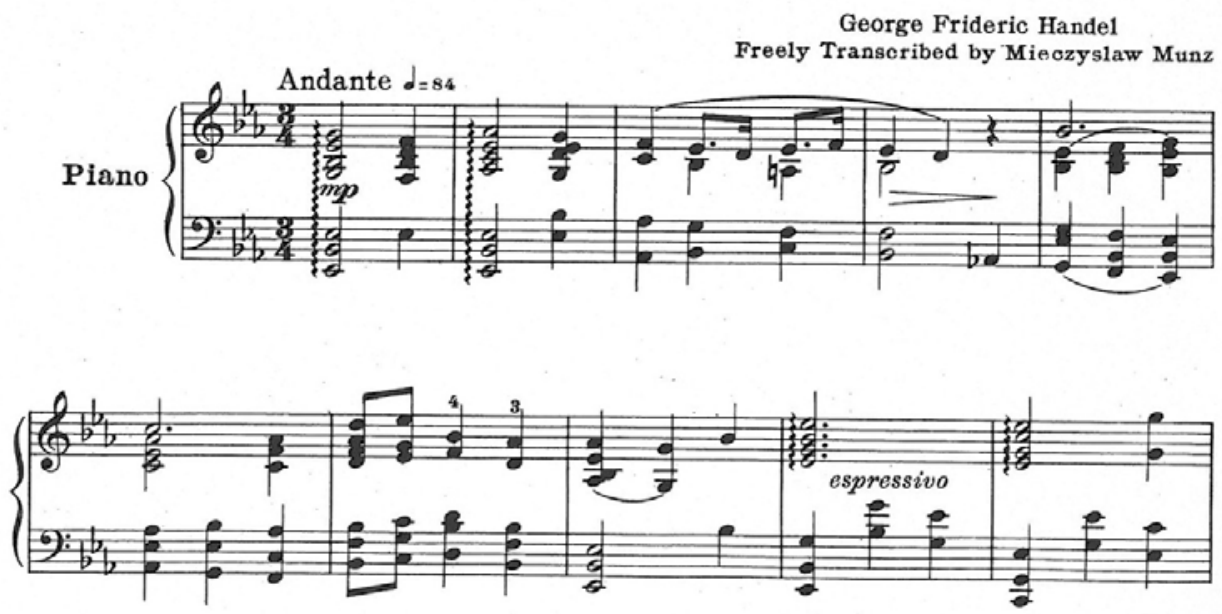

Figure 5. Minuet from “Berenice” published by G. Schirmer, Inc. 1940.

In 1941 Munz received the devastating word that his relatives, including his parents and his brother, perished in the “concentration camps.” 59 Looking at his circumstances, being deserted by his beloved wife and losing his entire family with the Nazi's brutal atrocities, one can hardly imagine Munz’s devastation as he lived alone in a foreign land. Munz had managed to establish a performing and teaching career and so, quite naturally, remained in the U.S., as given the continuation of the war, returning to Europe would not be an option. In addition to his performance engagements, Munz was hired again as a piano faculty member at The Curtis Institute of Music in April 1941. ${ }^{60}$

\footnotetext{
${ }^{59}$ Rosemary Mookerjee, "Mieczyslaw Munz: His students and his teaching” (M. M. thesis, The Catholic University of America, 1987) 6.

${ }^{60}$ Curtis Institute Archives, Contract paper in March, 1941.
} 
In 1941, Munz encountered a significant turning point when an irrevocable condition in his right hand and arm forced him to stop his active public performing career. In a letter dated December $2^{\text {nd }}$ to Mrs. Bok, six days before a major performance in New York, "I am playing next Monday in Carnegie Hall. That evening may be my last performance”. ${ }^{61}$ Mrs. Bok’s reply shows that Munz already had been suffering with pain: "Mr. Zimbalist told me of his talk with you and I don’t have the words to tell you how sorry I am. Do you have a wise physician? I should think there must be one who will know how to advise you and would think that rest in a warm climate, with certain treatments, would help.”62 On December 8, 1941 Munz performed Rachmaninoff's Rhapsody on a Theme of Paganini with the National Orchestral Association conducted by Leon Barzin in Carnegie Hall. It was a great success, but only a few people knew that he performed with his painful hand in that concert. A letter that he sent after the concert to Mrs. Bok stated: "Under difficult circumstances, everything went better than expected and at the end I received quite an ovation. Unfortunately, I personally know how much below my usual standard this performance was, but your kind words cheered me up and gave me hope for a full recovery in the future.”63 However, this concert may have been his last major public performance.

While the main cause of Munz's hand disability was unknown, there were many rumors circulating among his students, some blaming taxicab accidents and others believing it a result of possible nerve damage following the shocking news from Poland. ${ }^{64}$ To make things worse, he

\footnotetext{
${ }^{61}$ Munz to Bok, letter, December 2, 1941.

62 Mary Louis Curtis Bok to Munz, telegram, December 3, 1941.

63 Munz to Bok, letter, December 9, 1941.

${ }^{64}$ Rosemary Mookerjee, "Mieczyslaw Munz: His students and his teaching"

(M. M. thesis, The Catholic University of America, 1987) 6-7.
} 
received a termination letter for his teaching position from The Curtis Institute in May $1942 .{ }^{65}$ There was no clear indication explaining why he was terminated from the position, but one could conjecture financial problems at the Institute.

In the summer of 1942, Munz went to Hot Springs, Arkansas for a cure, without much success. It was there a medical doctor diagnosed his condition as "occupational neurosis." 66 As he continued to look for cures for his disability, Munz’s financial situation continued to deteriorate. According to the letters between Mary Curtis Bok and Munz, she periodically sent him money, about which Munz expressed much gratitude. Even during this difficult time, Munz was giving lessons at no charge to some of his students. The letters between Mrs. Bok and Munz regarding his piano student Walter Hautzig show the warm-hearted and noble person Munz was. Mrs. Bok said in the letter, "Walter Hautzig came politely to say good-bye and thank me for his term at The Curtis Institute. When I learned that you had given him a Scholarship all through this year, I felt this should have come from the Institute or me, since the whole situation stems from his being a student under you here.” ${ }^{67}$ And Munz replied, "When I offered the scholarship to Hautzig I did so to help him - because I know myself how blessed help can be at times.”68

As Munz bore such losses and financial problems, not only his body but also his emotional state suffered. He was the victim of circumstances beyond his control due to the war and his immigrant status. Munz’s letter of March 11, 1943 to Mrs. Bok described that he looked for work outside of music, trying to join the army but could not be accepted due to his age. He was also rejected from working in a defense plant or using his multi-lingual capabilities (Munz

\footnotetext{
${ }^{65}$ Munz to Bok, letter, May 19, 1942.

${ }^{66}$ Munz to Bok, letter, June 26, 1942.

${ }^{67}$ Mary Louise Curtis Bok to Munz, telegram, May 17, 1943

${ }^{68}$ Munz to Bok, letter, May 19, 1943.
} 
spoke fluent Polish, German, Spanish and English) as he was not a US citizen yet. In August 1943, he finally found a job working in a factory on the nightshift in Bridgeport, Connecticut, saying, "It is not easy physically, but much harder morally" and "I am trying to take it as brave as I can and I will be indeed happy to write to you more cheerfully as soon as my situation changes.” 69

It is not known how long Munz worked at the factory in Connecticut, but in 1946 a chance meeting in New York would bring a miraculous change in his situation. Reginald Stewart, whom Munz had frequently performed with, saw Munz on the street on Broadway in New York. According to Ann Schein, from an interview with Andrew Todd of KJAX-Aspen Public Radio: "Reginald Stewart took one look at him, and he was a completely destroyed human being."70 Reginald Stewart invited Munz to Peabody where he was the Director to join the piano faculty. This profound gesture of friendship and respect by Stewart marked a turning point in Munz’s life. 1946 also marks the year Munz became a naturalized Unites States citizen. $^{71}$

Since that meeting in New York, Munz began a new start for his life, dedicating the next 30 years to his students and becoming a busy and sought after teacher around the world. Munz taught at Peabody from 1946 to 1964. After Munz left Peabody, Dr. Peter Mennin, who was president of Juilliard, invited him in 1964 to teach at Juilliard, and he remained an important member of the piano faculty there for twelve years. During his teaching years at Peabody and Juilliard he also made frequent trips to Asia to teach. Some of his most famous students include

\footnotetext{
${ }^{69}$ Munz to Bok, letter, March 11, 1943 and August 23, 1943.

${ }^{70}$ Andrew Todd, KJAX-Aspen Public Radio: Interview with Ann Schein. https://www.youtube.com/v/zbmlk_fRIWo\&autoplay=1\&rel=0 (accessed February 24, 2016)

71 US immigration records (ancestrylibrary.com accessed February 28, 2016.)
} 
Emanuel Ax, Antonio Barbosa, Felicja Blumenthal, Alan Feinberg, Walter Hautzig, Hidemitsu Hayashi, Eugene Indjic, Jahja Ling, Charles Milgrim, David Oei, Reynaldo Reyes, Harold Rubens, Ann Schein, Ilana Vered, and Susan Popkin Wadsworth. ${ }^{72}$ Some of the students began their studies under Munz when they were as young as 10 years old, and often they considered Munz their musical father. His warm personality, gentle and calm demeanor, and commitment to guide and encourage them are among the many great characteristics that his students recall.

There are very few recorded examples of Munz's playing. He made eleven piano rolls for Ampico ${ }^{73}$ but never recorded a large scale work in the studio. There are a few extant recordings of live performances, however. In 2002, The Art of Mieczyslaw Munz was released by Americus Records, Inc., featuring Munz’s live concerto performances, six preludes by Chopin, and various short works, several being virtuosic transcriptions recorded from the historic piano rolls. David Dubal said about Munz’s playing: “His recording brings to us a sophisticated musicianship, a high-bred pianism with a formidable evenness in passage-work. The reading of Dohnányi’s Coppélia Waltz is delightful in his feathery finger work and elegant style.”74

This CD also includes two recently discovered broadcasts of Munz in major works for piano and orchestra. The first piece, recorded on October 17, 1940 was a performance of Mozart's Piano Concerto No. 20 in D Minor, K.466 with Frank Black conducting the NBC Symphony Orchestra. “His playing is marvelous, and we can appreciate Munz’s wonderfully clear sonority, precise and even articulation, transparent voicing, and beautiful singing line.” ${ }^{75}$ Another performance

\footnotetext{
${ }^{72}$ International Piano Archives at University of Maryland. "Mieczyslaw Munz Collection" http://www.lib.umd.edu/ipam/collections/mieczyslaw-muns (accessed February 26, 2016)

${ }^{73}$ Liner notes for "Ampico Rolls In The $21^{\text {st }}$ Century" recording. The author was able to locate seven (see Appendix).

74 David Dubal, The Art of the Piano: Its Performance, Literature, and Recording. (Hal Leonard Corporation, 2002), 252

${ }^{75}$ Mark Ainley, "The Piano Files: Magnificent Munz" www.thepianofiles.com/?s=Mieczyslaw+Munz (accessed February 22, 2016)
} 
featured on the CD is the December 8, 1941 concert performance of Rachmaninoff's Rhapsody on a Theme of Paganini with the National Orchestral Association conducted by Leon Barzin in Carnegie Hall, which Munz said may have been his last performance.

As Munz was a tremendous teacher in the USA, he was also a very revered teacher in Asia, particularly in Japan and Korea. Among the 'Mieczyslaw Munz Collection' at the International Piano Archives at the University of Maryland, there is a letter and a group photo from Korea, dated August 25, 1965. Mr. Bong-gi Kim, the president and publisher of the Korean Herald, in his letter to Munz, stated, "Your visit to Korea, though it was a brief one, threw encouragement and stimulation among the music circle in this developing country. Hope you will find the album not merely pleasing to your eyes but by keeping memorial photos you would teach Korean students with increasing interest. Please try to come again to Korea. You are always welcome!”76 Munz in fact visited Korean again in 1967 as shown in the photo below. (Figure 6)

${ }^{76}$ Bong-gi Kim to Munz, Letter, August 25, 1965. 


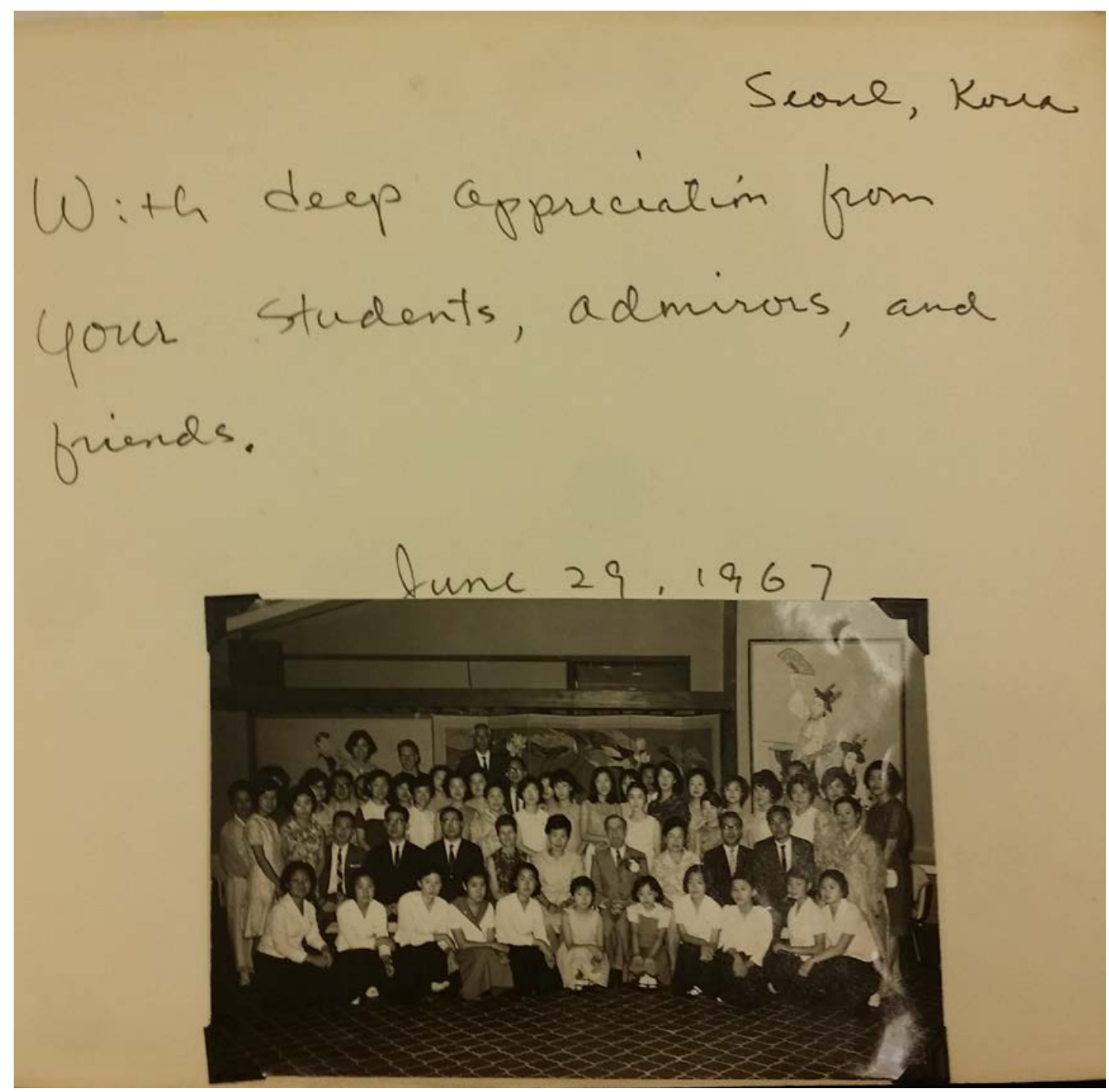

Figure 6. Group photo taken in Korea in June 29, 1967.

Munz was also interested in helping young performers advance their careers and become great artists. He was a founding member of the Board of Advisors of Young Concert Artists, Inc. He assisted Executive Director Susan Wadsworth (one of Munz’s former students) in choosing and coaching pianists selected for this prestigious organization. In 1975 Munz was invited to be a Visiting Professor at Tokyo National University. He took a sabbatical year from Juilliard and went to Japan. During that year, Munz became severely ill and had to return to the 
US in May 1976, four months before he was supposed to resume his teaching at Juilliard. ${ }^{77}$ Unexpectedly, Munz died on August 25, 1976 after suffering a heart attack at the age of $75 .^{78}$ During his last days, while in the hospital, Munz requested a rabbi to come to meet with him. ${ }^{79}$ At the funeral, the rabbi recounted the story of his hospital visit, saying Munz was "one of the most remarkable human beings he had ever met” and that Munz had told him the story of his marriage to Nela. Munz had asked the rabbi to do him one last favor: to reconvert him to Judaism. This was done, and Munz received a Jewish funeral and was buried in Mount Carmel Cemetery, in Glendale, Queens County, New York. There was no surviving immediate family. His gravestone read: Mieczyslaw Munz, Concert Pianist and Teacher.

Munz lived a lonely life after losing both his family and his beloved wife, and was forced to stop his performing career at his peak. However, all these hardships did not deter him from his continuous passion for music and a noble devotion to his students. His legacy lives vividly through each of them to this day.

\footnotetext{
77 Emmett M. Ford, “Biographical Sketches: Mieczyslaw Munz” AMICA 14, \#3 (April, 1977): 72-73.

78 Obituary of Mieczyslaw Munz, The Daily News, August 26, 1976.

${ }^{79}$ Recounting of Munz's last days and funeral is from Ann Schein
} 


\section{CHAPTER II}

\section{INTERVIEWS WITH STUDENTS OF MIECZYSLAW MUNZ}

He was everything a great teacher can be and more. ${ }^{80}$

Mieczyslaw Munz was not only a great concert pianist, but he was also a gifted teacher who trained many world-renowned pianists. His teaching career started early in his 20s even though he was an active concert artist at the same time. In addition to being Busoni's assistant in Berlin, his first teaching assignments in America were at the Cincinnati Conservatory of Music (1925-1930), The Curtis Institute of Music in Philadelphia (1930-1932; 1941-1942) and The Peabody Institute of Music in Baltimore (1930-1933). Later he became a full time faculty member at Peabody (1946-1964) and at Juilliard (1964-1976). In some respects, Munz was a reluctant piano teacher at first, having been a great concert artist and focused primarily on performing. ${ }^{81}$ Munz, however, brought his great artistry into the teaching studio and as a teacher for more than 35 years, he began a legacy that has produced countless pianists. Emanuel Ax, who studied with Munz from 1964 to 1975, once said, "For me, simply no other teacher was necessary," while Susan Wadsworth recalled that Munz “was able, with the subtlest of suggestions, to guide each student to develop their own talent and musicianship.”82

Austrian-born American pianist and teacher Walter Hautzig (b. 1921) is one of Munz’s most prominent and dedicated pupils. Hautzig studied at the Vienna Academy of Music, but left

\footnotetext{
${ }^{80}$ Brochure from The Mieczyslaw Munz Scholarship Fund, Inc. quote by Hautzig.

${ }^{81}$ Andrew Todd, KJAX-Aspen Public Radio: Interview with Ann Schein. https://www.youtube.com/v/zbmlk_fRIWo\&autoplay=1\&rel=0 (accessed February 24, 2016)

82 International Piano Archives at University of Maryland. "Mieczyslaw Munz Collection" http://www.lib.umd.edu/ipam/collections/mieczyslaw-muns (accessed February 26, 2016)
} 
Austria after the rise of the Nazis. He went to Jerusalem and studied at the Conservatory and in 1939 he came to the USA, and continued his musical education at The Curtis Institute of Music with Mieczyslaw Munz, graduating with honors. He also studied privately in New York with Artur Schnabel. In 1943 he won the Town Hall Endowment Award in New York. Walter Hautzig made his debut at Town Hall in New York in October 1943 and became a U.S. citizen in 1945. After World War II, Hautzig made tours worldwide, with successes in the USA, Latin America, Europe, and throughout the Near and Far East. During his long career as a concert pianist, he has given recitals and orchestral appearances in over 50 countries, earning particular acclaim in Japan, where he has also recorded extensively. Hautzig was Professor of Piano at The Peabody Institute of Music in Baltimore from 1960 to 1987 and he founded and was President of the Mieczyslaw Munz Scholarship Fund until 2014 when he retired and Ann Schein took on the role of President. ${ }^{83}$ Hautzig is also the longest living pianist on the Steinway Artists roster and in October 2010, he gave his $90^{\text {th }}$ birthday recital in Steinway Hall. ${ }^{84}$ Hautzig was not a just student of Munz, but also a close and dedicated friend. In 2007, he sent a letter to the editor of Keyboard Companion after the journal published Ann Schein’s tribute to Munz in the Winter 2006 issue. In the letter, he spoke about Munz’s style of teaching, in particular describing how generous he was:

To the Editor:

Thank you for Ann Schein’s touching tribute to Mieczyslaw Munz. Having studied with Munz, both at Curtis and in New York, it brought back precious memories of many hours spent with this wonderful man. As Ms. Schein rightly states, he never had a "system" or special method. Instead he applied his vast knowledge and experience to every lesson and tried to solve whatever problems or obstacles were facing us-and he usually succeeded. In other words he did not try to tell us what he knew but rather what he did not know.

\footnotetext{
${ }^{83}$ Aryeh Oron, "Short Biography: Walter Hautzig (Piano)", Bach Cantatas Website http://www.bachcantatas.com/Bio/Hautzig-Walter.htm (accessed March 4, 2016)

${ }^{84}$ Brochure from The Mieczyslaw Munz Scholarship Fund, Inc.
} 
He was very tolerant and never claimed to have a monopoly on the truth. Just as he allowed Ann to play for Rubinstein, not withstanding their "special” relationship (Munz was the first husband of Mrs. Rubinstein), he never objected to my playing for Artur Schnabel. A lesson with Munz did not end when the hour was over. He was extremely generous and helped his students in many ways with their careers. I am sure I speak for many of my colleagues when I say we shall always treasure his memory. ${ }^{85}$

Due to health reasons, Walter Hautzig was not available to be interviewed for this research paper. However, his experiences studying with Munz have been well documented and are an important resource for understanding Munz's approach to teaching. Hautzig said once about this indelible legacy of Munz’s teaching: “Munz was absolutely indispensable to my career. He was everything a great teacher can be and more. He taught me virtually everything I know about the art and business of playing the piano professionally. He treated each of his students as a unique person and taught each individual according to his or her strengths.”"86

Seven former students of Munz, Faye Bonner, Paula Forrest, Jeffry Marcus, David Oei, Ann Schein, Robert Swan and Stefan Young, all kindly agreed to contribute their memories and experiences for this research paper. Each of these esteemed pianists was given the same questions. Some of the artists answered each question, while others chose to write their answers more freely. Below are their answers along with their own biographies.

\section{FAYE BONNER}

Faye Bonner studied with Pasquale Tallarico and Nadia Boulanger at The Peabody Institute of Music, where she was the youngest student at the time to be admitted for a double major in piano and voice. A graduate of the American Academy of Dramatic Arts, New York,

\footnotetext{
${ }^{85}$ Walter Hautzig, "To the Editor" Keyboard Companion 18, no.2 (Summer, 2007):47.

${ }^{86}$ Quoted by Walter Hautzig in Brochure from The Mieczyslaw Munz Scholarship Fund, Inc.
} 
she subsequently studied piano for eight years while abroad, first with Midhat Femnin (a student of Cortot and Director of the Ankara Turkey Conservatory), then with Dusko Trbojevic at the Belgrade Conservatory and finally in Moscow for two years with Belkin (affiliated with the Moscow Conservatory). Upon returning home, Ms. Bonner continued her studies with Mieczyslaw Munz. A member of MTNA and the National Guild of Piano Teachers, and a former teacher at the Washington Conservatory of Music in Washington, D.C., and the Norwood School in Bethesda, Maryland, Ms. Bonner has had winning students in county, state, national and international competitions.

\section{Where did you study with Munz and for how long?}

I studied with Munz in Washington for three winters.

\section{What were Munz's strengths as a teacher?}

He was a problem solver and he got you through the music. His organization as a teacher was superb. In fact, he taught me how to teach. He always had you start with some kind of technical exercise. In the beginning when I would first start with him, he would have me do a scale or arpeggio, but then after he got to know me it was just a warm up. I would play a scale, and that was it. When I would ask for technical exercises, he would say, "You don't need any." I practiced four hours a day to do simple music, not music of any kind that I had never done before but just to get through something like a Bach invention. This right hand would have to relearn everything. ${ }^{87}$ So he would have you go through a piece. He would have you play your piece and then he would go back, and anything that he heard which was a little bit off, whatever

\footnotetext{
${ }^{87}$ Faye Bonner studied with Munz after having had a major surgery on her arm, which left her with limited use and coordination problems. Munz had a private studio in Washington, D.C., traveling from New York twice a month to teach a variety of students, including area piano teachers.
} 
it was, his hand would come down on yours; he'd stop and he would solve the problem. If it was a finger weakness, he would give you an exercise for it, which you would do right there. And then you would play the passage and it would be worked out. If there were unevenness in touch, he would reorganize the fingering so that the strong fingers were always able to modulate the tone and match the tone. If it were pedal, he would suggest less pedal or more pedal. But his strength was that he was a problem solver, so when I left, I knew exactly how to practice the piece and what to do with it. When I came in the next week, if I worked on it, it was gone, and then he would move on to the next piece. We went through tons of material; he really moved you very fast and if I wanted to memorize, I could. But he didn't care whether I memorized or not, at least not with me because I wasn't doing any concerts at that time. He was just teaching. If he heard a weakness in a trill, he would change the fingering. For instance, one of his favorite exercises was: say you were doing something like 423 1, 423 1; he would have you hold 42 and then very slowly lift your fingers 3 1, 3 1, 3 1. Then you would hold 31 and you would very slowly lift your fingers 4 2, 4 2, 4 2, and then you would find that you could do it so evenly. It was incredible. I use that exercise all the time with my students when there is an unevenness in thirds or fourths. And because of that you ended up with a really fine piece. There were no uneven parts to it at all.

\section{Did Munz recommend or favor particular technique exercises (i.e., Czerny,}

\section{Cramer, Hanon, Liszt, etc.)?}

I think he would probably ask me if I did any technical exercises and I always did Hanon and I did it a certain way. Gina Bachauer had a way of practicing Hanon which Rachmaninoff also did. I did it that way, and Munz liked that idea. It was holding the first note of a Hanon exercise and then repeating exercises $C E F G$ and then you would repeat A G F E, A G F E, A G 
F E, three times. And you would hold the first note so the muscle on the outside part of the hand gets a lot of work. With older students or teenagers, and they're using the fifth and fourth finger over and over again, it really does make the hands very secure. Munz liked that idea.

I studied with Munz for one year and I asked if he would take my daughter and he did. She studied with him her junior and senior year in high school. He moved her rapidly through repertoire. She was so good that when she went to Kenyan College for her undergrad, the head of the music department came by and heard her playing the piano and he said, 'Why aren't you a music major?' and she said, 'Well, I'm an English/French major.' And he said, 'we will give you free lessons your whole time here if you will just play in two recitals a year.' That was how good she became under him in two years. It was amazing. Now she had Czerny and she had Hanon and he gave her the early Czerny Op.299. She didn't do the later one, Op. 740, I don't think with him at all. But I didn't do any of that with him. I did do some Moszkowski etudes but I asked to do them. For young people, it was Hanon and Czerny and later on it was Moszkowski, which he liked.

\section{Did Munz create specific technique exercises which you learned from him? If so, could you describe them and for which works, if any, these exercises were intended?}

There was the holding of the fingers, the 42 , and playing slowly, lifting as high as you can without tension 1 and 3, and then holding 1 and 3 and lifting 2 and 4 without tension very slowly. Or if you had a passage where you were holding 524312 and you couldn't manage that 54 evenly, because you're holding the 25 and you're going to 4, he would go ahead and do the same thing with that. He would have you hold the 52 and then play 14 slowly and then hold 41 and play 52 slowly, the same kind of exercise. 
He also liked to accent. If you had four 16ths, for instance, I did the Schubert impromptus with him. I had never done those before, and there was an unevenness. The other thing that was very amusing, he said, 'Don't expect me to know any opus numbers.' I was so grateful because I could never remember them either. So he used to try to tell me what piece to play: 'Well, it's the Impromptus" and "I think it's number two or number three." Or he would tell me the key and

that would be it. Anyway he liked to accent $16^{\text {th }}$ notes for evenness: ones, then twos, then threes, and fours. He did not believe in playing in rhythms. Lots of people do that, but he said that achieves nothing. But I remember asking him about that. He would change fingerings for you. That was also a technical thing. If you had a problem, mostly about the tone had to match and if it didn't match then he would become concerned and he would find a way, assuming that it was a finger weakness. He would figure out some way to give you a little exercise that would work it out and that was it. Munz fingerings were so special that often after his death, people would call me (people that I did not know at all) and ask for Minz's specific fingerings of pieces they were working on.

\section{Did Munz teach a particular routine or have a specific approach for scales,} chords, and arpeggios?

I don't remember anything about scales, chords, and arpeggios, although he put my daughter on a regimen of scales and arpeggios. I don't think he did much about chords.

\section{What were some of the practice techniques Munz taught? Did he have special} advice about memorization?

He had no advice about memorization. He never talked to my daughter about memorization or me. We just memorized whenever we felt like it. 


\section{Did Munz demonstrate throughout the lesson? If so, how would you describe}

\section{Munz's playing?}

Well, only once did he demonstrate. He became so upset with me because I couldn't get something correct with the interpretation. I just remember that it was a Chopin prelude, and he said, “Oh, oh, oh” and so I got up. He didn't talk very much - he talked very little, very sparse conversation when he was teaching. I got up, and he sat down and said, "It should be like this" and then he played it. Obviously he never even had to think about that prelude, he just played it. Then I sat down and he said, 'DO IT!' and I did it. If you were fumbling, he would just put his hands on you and say, “Just do it. Don't think. Just do it.” And I would do it.

He used to demonstrate for my daughter, She said she remembers his hands being very thick and broad and she said he played with such lightness. She said, 'Mom, you couldn't believe that his fingers could create such a light and marvelous touch.”

I think he depended on ear. He was very funny about my playing. Lots of teachers studied with him and they would give up because they would say he doesn't tell you how to do anything. But I felt at his level he shouldn't have to tell you. Every now and then when I would finish a piece for him, he would get up and run out of the room and I would hear him saying to Virginia Dulasky, 'Did you hear that? Did you hear that?' and then he would come back in and never say anything to me. So he was not one to praise you. He never said anything to me at all that he liked my playing or anything except I know he did because there were so few comments. Other teachers said that they couldn't get past the first measure with him. I do remember saying something about my daughter to him. Her name was Jocelyn but we called her Dickie, and I said to him that Dickie will never be a concert pianist. He put his hands on mine and he said, 'Oh no, don't ever say that. You don't know.' She was very musical. So he really encouraged in a very 
subtle way. I used to come out of my lessons just dying to come back to piano and I think that is a sign of a wonderful teacher.

\section{What do you consider the most important concept you learned from Munz that}

\section{has stayed with you in your own teaching?}

Well it's kind of an interesting one. He never interrupted you when you first played the piece. He always let you play all the way through when it was the first assignment. With some teachers, you'll hear a student start out and then immediately after the fourth measure you think 'oh, the rhythm is wrong' or 'oh, too much pedal' and you stop them and correct it right away. That was the most important thing that he taught me, that you must respect what the student is doing. Let the student play the piece then go back and correct whatever needs to be corrected. By doing that the student has a feeling of achievement, that they've done something and have gotten all the way from A to Z and it's all there. So if you go back, they don't feel so badly. They

feel like they have worked pretty well and it has worked pretty well. I think that and the problem solving because I problem solve all the time.

\section{How would you describe Munz's approach to developing students' interpretive}

\section{abilities?}

Well I can't tell you that because he never worked on interpretation. The only thing I remember him saying to me was - it was very funny - I was doing one of the Impromptus, and it has a middle part. I was getting very engrossed in it and crescendoing all over the place and the second time, not the first time, he said, 'It's a little piece.' That's all he said so immediately I stopped and went back to minimalizing everything. That is very funny and that is the only thing I remember him saying to me about my interpretation. But you have to remember I had many good teachers before Munz. I had studied with four concert pianists by that time and so even though I 
couldn't play anything because of my hand he was very careful to give me pieces of what he thought I could do. He understood that I was struggling. So he started me on my first piece with him - Debussy's Children's Corner Suite, the Dance with the Doll. I remember looking at it and thinking I can't do this now. I started when I was six with a woman who got her $\mathrm{PhD}$ in Germany before World War II and she was fantastic. She was at McDaniel College and then went on later to teach at Eastman. She was there because of the war, at McDaniel, because she went where she could get in. I was very fortunate I had her for ten years. Then I went to Peabody and studied with a concert artist there; then I went to Turkey and studied with a student of Cortot. Then I went to Yugoslavia and had three years with the top performing artist. Then we came back to this country and I didn't do anything because I had children. Then we went to Russia and I had studied with someone there. When I came back I had the surgery within a year and that's when I started to teach, I didn't think I knew enough to teach, believe it or not, so I was constantly looking, and that's when I started with Munz.

So I can't tell you what his interpretative abilities were and I don't know that he did much with my daughter. He would say 'faster' or 'slower' or he would circle piano or forte in the music. He had a really interesting way of doing it (and I don't remember which one was which): the first time you had a problem I think he circled it in blue. If you came back with the same problem he would circle it in red. He used colored pencils. Always, the two colored pencils were on the piano. I think red was last and then blue first. I would have so few marks on my music, but my daughter would have a few. They would be at the trill or where she missed a note like a B-flat and played a B instead. I don't remember which prelude or fugue it was, it started in minor and I looked up at him and finished it in major and I thought he'd fall off of his chair 
laughing. He thought that was hysterically funny. But I didn't. I thought how could I have done that!

\section{Which repertoire or aspect of performance do you feel you learned the most} about from Munz?

I had a problem with my coordination and Munz understood that so he gave me a steady diet of pieces which progressed. I started out with easy Debussy and some easy Beethoven that I had never done and then some Mozart sonatas, By the time he left I was doing the F-minor variations by Haydn and bigger pieces by Brahms, and we probably started a Chopin sonata. We were into much bigger repertoire after three years. He was very good at pacing a student's abilities. I think that's probably one of his strengths: knowing how to pace the repertoire to the student's advantage.

\section{Were there particular pianists Munz recommended or preferred?} Munz never talked about any pianists.

\section{Is there anything else you would like to add about Munz and his teaching and} artistry?

I really think the relationship I had with Munz was, because he had known me when I was so young as a student at Peabody while he was there, a little bit special. For instance we would always give him a very special bottle of brandy, and he was thrilled with that. He would talk about personal things and his students, like Korean students - he thought they were very musical. One time he told me a joke about when he was walking home from Peabody years ago. He would have been 50 years of age. He walked this girl home because he didn't think she should walk home alone. And he said, 'You know, she made up to me', (His English was not all that good; at times, it was very heavily accented), 'and I looked at her and I thought, 25 years too late.' That's 
the kind of discussions we had. Munz gave me tickets to go see Emanuel Ax's recital at Alice Tully Hall in New York when he won the Rubinstein Competition. I took my daughter and another student. It was a gorgeous recital. Everything with Munz was about sound, and Ax benefited from that. Ax's playing was exactly a result of Munz. No note is ever out of place as far as your ear goes. Munz sat in a box and a very glamorous woman was sitting with him.

Somebody told me that it was Nela. Now, she may have been there out of deference for her husband because it was his competition. Munz cried all the way through the recital. Munz gave me a copy of the telegram that Arthur Rubenstein sent him. He was very proud of that. (Figure 7)

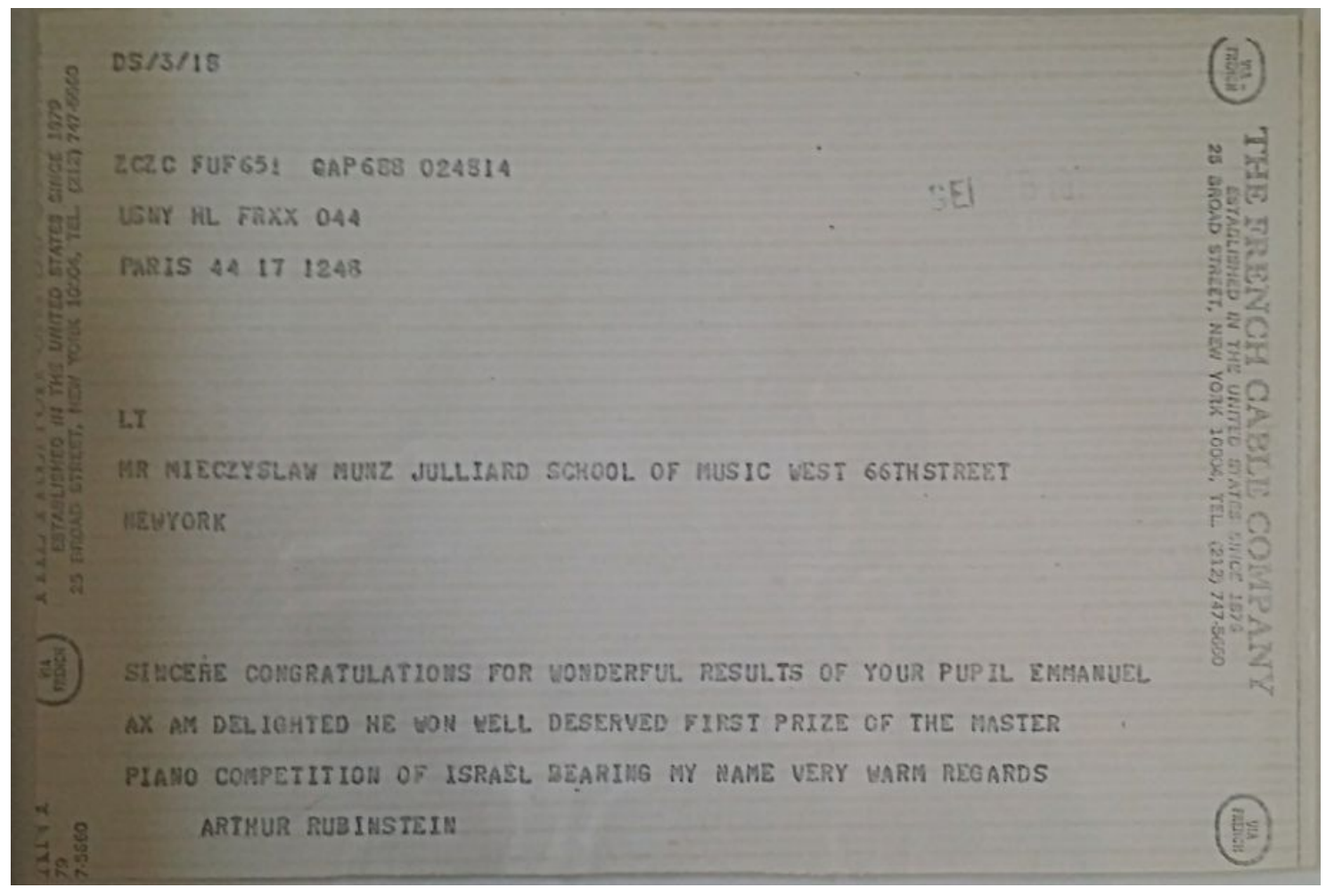

Figure 7. Photo of the telegram Rubinstein sent to Munz. 


\section{PAULA FORREST}

A native of Washington, D.C., Paula Forrest grew up in a family of professional musicians, going back as far as her great-grandparents. Her father, Sidney Forrest, who was the principal clarinetist of the National Symphony Orchestra in Washington, D.C., made numerous commercial recordings of chamber music, and served on the clarinet and chamber music faculty of The Peabody Institute of Music in Baltimore for 40 years. Her mother, Faith Forrest, was a professional pianist and her first piano teacher. Her teachers also included Mieczyslaw Munz, Eugene List and Marvin Blickenstaff. Paula attended the University of Michigan in Ann Arbor, pursuing a liberal arts degree while continuing serious piano studies. Her master's degree is in musicology, from the University of North Carolina in Chapel Hill. Ms. Forrest has worked at the Music Division of the Library of Congress, where she was coordinator of the chamber music concert series and broadcasts for thirteen years. Since moving to Ames, Iowa in 1988, she has performed and taught extensively, and her students have been prizewinners in district and state auditions. She has taught at Simpson College, Interlochen Center for the Arts, and served as faculty accompanist at Iowa State University. She is also the Artistic Director of the Ames Town \& Gown Chamber Music Association featuring world-renowned musicians.

\section{Where did you study with Munz and for how long?}

I studied with Mr. Munz for eight years in Washington, DC, where he taught on Sundays. The other six days of the week, he taught at Peabody, Juilliard, and his private studio in NY (Saturdays). During the years 1961 -1969, (from 5th through 12th grade) my lessons took place at the elegant townhouse home of Ann Schein's parents on Bancroft Place in Northwest Washington. During the last year or so, I may have taken lessons at the home of Virginia Dulasky, an adult student of Mr. Munz. Or perhaps that was just occasionally; I'm not sure. 


\section{What were Munz's strengths as a teacher?}

Mr. Munz's personality of quiet charm and humor worked very well for me, even though I was only 10 years old when I started lessons with him. For example, he would ask if I'd prefer to practice a section of a piece 5 or 10 times. Of course I'd say "5 times," and he'd respond "Good. So practice it 5 times with the repeat!" -- then he'd smile. Or, if there needed to be a separation of one part of a piece from the next, he'd say "Don't mix the sardines with the chocolate sauce." His teaching of technique was impeccable. He never let a small mistake go by without rethinking the fingering, or developing an exercise on the spot to prevent it from happening again.

\section{Did Munz recommend or favor particular technique exercises (i.e., Czerny,} Cramer, Hanon, Liszt, etc.)?

What I mostly remember were the Moszkowski Etudes de Virtuosité. We did scales (major, harmonic and melodic minors) and arpeggios (major, minor, dominant and diminished 7ths) weekly, in the "Russian style."

4. Did Munz create specific technique exercises, which you learned from him? If so, could you describe them and for which works, if any, these exercises were intended?

Practicing passages in various rhythms, repeating certain cells within a passage to exercise the weak fingers, holding certain fingers down while practicing the notes around them.

\section{Did Munz teach a particular routine or have a specific approach for scales,} chords, and arpeggios?

Scales (major, harmonic and melodic minor)--the Russian method of ascending, then contrary motion, etc. Arpeggios the same way. Play two scales a day, in tritone sequence. e.g., 
one day $C$ and F\#, next day $C \#$ and $G$, next D and A-flat , E-flat and A, etc. Same Russian pattern for major/minor, dominant and diminished 7 arpeggios.

6. What were some of the practice techniques Munz taught? Did he have special advice about memorization?

See number 4. No, I guess I memorized easily, so the subject did not arise.

7. Did Munz demonstrate throughout the lesson? If so, how would you describe Munz's playing?

Only occasionally did he demonstrate due, I suspect, to his problem with his left hand 4th and 5th fingers. But when he did, it was sparkling.

8. What do you consider the most important concept you learned from Munz that has stayed with you in your own teaching?

How to approach technical difficulties and how to conquer them through the various means.

9. How would you describe Munz's approach to developing students' interpretive abilities?

This was what he covered the least with me. I think he wanted to build up technique and a substantial repertoire first.

10. Which repertoire or aspect of performance do you feel you learned the most about from Munz?

Mozart and Beethoven Concertos (with each I was a concerto winner at Interlochen), Chopin (etudes, etc.), Debussy. He didn't really teach much literature of the 20th century beyond 
Debussy. He also taught some of the less well-known pieces of the composers, such as Debussy Nocturne, General Lavine, etc.

\section{Were there particular pianists Munz recommended or preferred?}

This was never discussed. But quick anecdote: when I was a young teen-ager, Mr. Munz told me he had acquired a new student, a few years older than I. He said: "You watch for this name in the future: His name is Emanuel Ax." Another fabulous young student at the time was David Oei.

12. Is there anything else you would like to add about Munz and his teaching and artistry?

My lessons with Mr. Munz are so memorable. I still have all of my music with his markings, and I use it constantly with my students. Fortunately, my mother also came to the lessons and took notes (she was a pianist, as well), or I would not have been able to remember everything. Just one small anecdote: When I first played for Mr. Munz in order to be accepted as a student, he assumed I was aspiring to a music career, which I certainly was not, at age 10 or 11. So, when he suggested that I get a shortened school schedule so I could practice several hours a day, I nearly fainted. So then, he said he'd like to have me practice 2 hours a day. That still sounded truly awful to me at the time. So we "compromised" on one-hour-45 minutes. And I don't think I ever practiced one minute more! When the timer went off, I was gone!

\section{JEFFREY MARCUS}

A scholarship student of Frances Mann and Mieczyslaw Munz at the Juilliard School, Jeffrey Marcus received a Bachelor of Science degree in Piano. He went on to obtain his Master 
of Music degree as a student of Martin Canin at the State University of New York at Stony Brook where he was a teaching assistant. Mr. Marcus has toured extensively: in Reykjavik, Iceland; Oxford and London, England; Poznan and Warsaw, Poland; Munich and Hamburg, Germany. He was the pianist for the North American Premiere of Kristoff Penderecki’s "Strofe" and for the first complete performance of Chopin's Songs with the American mezzo soprano Elizabeth Patches at Alice Tully Hall, Lincoln Center. His performances have aired all over the world: on WQXR and WNYC in New York; BBC, England; Süddeutscher Rundfunk, Norddeutscher Rundfunk and Hessischer Rundfunk in Germany. His solo recital debut at Merkin Hall in New York took place in October, 1985 under the auspices of the Oberon Foundation and was received with high critical praise. Jeffrey Marcus has collaborated with many internationally celebrated artists including the American cellist Rebecca Rust, first solo Bassoonist of the Munich Philharmonic Friedrich Edelmann, Chilean mezzo soprano Victoria Vergara, Icelandic soprano Gudrun Tomasdottir and the German cellist Tilmann Wick. For many years, Mr. Marcus has maintained a private teaching practice on Long Island's North Shore. He numbers among his many successful students the professional musicians Noby Ishida, Derek Wieland, Rob Burger and Carey Brown. A past member of the New York State Council of the Arts Decentralization Committee, Mr. Marcus has served on the faculty and as a member of the Board of Directors of the State University of New York at Stony Brook Pre-College Music Program. ${ }^{88}$

\section{Where did you study with Munz and for how long?}

I began my lessons with Mieczyslaw Munz at the Juilliard School in September 1964 and worked with him until June 1968.

\footnotetext{
${ }^{88}$ http://www.jeffreymarcuspianist.com/biography/index.html (accessed March 4, 2016)
} 


\section{What were Munz's strengths as a teacher?}

Munz was an artist of the first rank and an extraordinarily naturally gifted pianist. He understood the physical challenges of piano technique. As someone who had no weakness, he was able to convey his philosophy on both the broad scale and in its application to specific repertoire.

\section{Did Munz recommend or favor particular technique exercises (i.e., Czerny,}

\section{Cramer, Hanon, Liszt, etc.)?}

Munz preferred to generate technical exercises from repertoire. Thus, the Chopin Etudes, Moszkowsky Etudes, Rachmaninoff Preludes and Etudes Tableaux were mined for their musical and technical contributions to the growth of young artists.

\section{Did Munz create specific technique exercises which you learned from him? If so,} could you describe them and for which works, if any, these exercises were intended?

Munz could be quite specific and suggested such techniques as doubling, rhythms, holding exercises etc. In Chopin's double note etude opus 10 no. 7 Munz suggested a slight hand motion towards the body on the thirds and the opposite movement on the sixths. The lower right hand voice was doubled while the upper voice played normally. This process was then reversed. Rhythms were suggested in groups of six and in groups of four. The last movement of the Chopin Sonata in B flat minor, opus 35, Munz taught as a technical study with fingerings quite different from the ones he would suggest for performance. 


\section{Did Munz teach a particular routine or have a specific approach for scales,}

\section{chords, and arpeggios?}

Munz's approach to arpeggios was noteworthy. He was such a natural player and not given to elaborate explanations in English. I once asked him for his philosophy regarding arpeggio playing. He smiled and moved his hand and arm sideways in the air with no twisting or artificial movement. In right hand passages descending from the top of the piano in arpeggiated figures Munz always preferred the hand to be angled slightly to the right rather than the most often observed wrist twisting in orthodox pedagogy.

\section{What were some of the practice techniques Munz taught? Did he have special} advice about memorization?

I memorized with ease and received no suggestions.

\section{Did Munz demonstrate throughout the lesson? If so, how would you describe}

\section{Munz's playing?}

Munz rarely demonstrated at the piano. I recall two vivid examples of his playing at the lesson. He played for me the opening of the slow movement of the Chopin B minor Sonata. His limpid tone colors and subtle rhythmic nuance sounded so essential. I felt I was being presented an extraordinary gift from the past brought fully to life in the present. The memory of those moments is as fresh for me today as it was fifty years ago when Munz played those measures for me. Munz also played for me the slow movement of the Schumann F sharp minor Sonata. Again his tone color and rhythmic flexibility have remained a beacon for my own interpretations of this piece. 


\section{What do you consider the most important concept you learned from Munz that}

has stayed with you in your own teaching?

I am able to play the piano eight or ten hours in a day when preparing for concerts as I approach my seventieth birthday. I have no aches or pains associated with piano playing. Munz' philosophy regarding the physical approach to piano playing has kept me injury free. Munz, unlike many other teachers, believed in the necessity of his students finding their own musical answers rather than in spoon feeding the standard interpretative answers he well knew. Thus no Munz student played like another Munz student as we were encouraged to do our own "soul searching.” As a teacher, I believe most strongly in challenging my students to trust their intuition and realize that each musical journey is unique while at the same time demanding a high level of faithfulness to the printed page.

\section{How would you describe Munz's approach to developing students’ interpretive} abilities?

(see above)

\section{Which repertoire or aspect of performance do you feel you learned the most}

\section{about from Munz?}

Munz was quite eclectic and had a kaleidoscopic knowledge of the nineteenth and early twentieth-century repertoire. He included Scriabin, Medtner, Cesar Franck, Faure, Poulenc, and many other composers not usually encountered by Juilliard students. Of course he also taught the standard repertoire from Handel and Bach through Rachmaninoff. 


\section{Were there particular pianists Munz recommended or preferred?}

Munz spoke glowingly of Rachmaninoff. He admired Josef Lhevinne. He was excited when he heard the young Martha Argerich play in New York for the first time. We went together to hear Vladimir Horowitz's return concert at Carnegie Hall in 1965. We stood in the hallway of Carnegie Hall as Arturo Benedetti Michelangelli passed by heading to the Carnegie Tavern (probably to steady his nerves) just before his performance. Munz loved young Emanuel's playing!!!

12. Is there anything else you would like to add about Munz and his teaching and artistry?

I have numerous stories and anecdotes about Mieczyslaw Munz that go to the heart of his complex and playful character. He was so many years removed from us and represented a musical culture that no longer existed. Those of us who were impressionable and open were able to take away far more than the details of the way Munz taught.

\section{DAVID OEI}

David Oei, pianist, was a soloist with the Hong Kong Philharmonic at the age of nine and has since performed with major orchestras including the New York Philharmonic, Pittsburgh, and Baltimore Symphonies. He is the winner of five Interlochen Concerto Competitions and the

Concert Artists Guild, WQXR Young Artists, Young Musicians Foundation and Paul Ulanowsky Chamber Pianists Awards. A perennial fixture on the New York City chamber music scene, he has made guest appearances with the Audubon Quartet, Claring Chamber Players, Da Capo Chamber Players, New York Philharmonic Ensembles, St. Luke's and Orpheus Chamber 
Ensembles and the Chamber Music Society of Lincoln Center. A founding member of the Aspen Soloists and the Intimate P.D.Q. Bach, he is also currently a member of the Elysium Chamber Ensemble, Festival Chamber Music, Washington Square Festival Chamber Ensemble, the LED Trio and the HD Duo with pianist Helene Jeanney besides enjoying a longtime collaboration with violinist Chin Kim. His television credits include Leonard Bernstein's Young People's Concerts, CBS News Sunday Morning and the Today Show. He has recorded a wide range of chamber works for Delos, ADDA, Vanguard, CRI, Pro Arte, Arabesque, Albany, Grenadilla and New World Records. Mr. Oei lives in New York City with his wife, violinist Eriko Sato, and their pit bull Marian. ${ }^{89}$

Mr. Oei chose to submit these comments:

In my excitement over this wonderful project, I neglected to realize that I might not be able to offer much contribution. As I read the issues on the questionnaire it suddenly dawned on me that my experiences with this great man might not be at all typical or representative of his teaching.

I met Mr. Munz at the age of ten when during his yearly Asia tour he selected me to receive a scholarship to the Peabody Conservatory to study with him. I think from day one he had a particular interest in me because my pianistic style was very reminiscent of his own. Coupled with the fact that I really didn't have any trouble playing the piano, could play anything on sight, he probably gave me less specific instructions than he gave to some other students. Technically he did enjoy giving me acrobatic fingerings, which he delighted in using himself. Musically he encouraged me to be myself.

${ }^{89}$ http://davidoei.weebly.com (accessed February 6, 2016) 
Although he retired due to pains in his fingers, some feel psychologically induced, he was a magician in the studio. He could definitely still play up a storm when excited, which was often during my lessons. Again, I suspect he was particularly excited by my playing because it was so close to his style.

Munz was like a father to me. My own father passed away when I was 6 years old. I was with Munz for about 7 years. I broke away because I finally realized that the life he had envisioned for me was not the life I needed to live. Emanuel Ax inherited that life.

So this great man was probably more of a father to me than a teacher, not giving me much of the more specific instructions he might have given others. What he gave me most was his love and his love for music.

I don't recall too much specifics. After all it was half a century ago! But I do recall and still make use of doing turns and similar situations with his favorite 2, 4, 3 and sometimes trilling with 1, 3, 2, 3. Also I would do daring jumps and crossovers, ala Chico Marx. But like I said, I don't know how much that was common among his students.

We had great similarities and great differences, so I believe the parting was very sadly unavoidable. Musically he was a traditionalist, much like Rubinstein, nothing past Debussy. But he was far more virtuoso in playing ability, like a much lighter and more elegant Horowitz. I, on the other hand, loved and felt equally comfortable and capable in all styles, including contemporary, jazz, blues, rock, theater, etc.

Our love for music, piano playing and each other is something I will cherish forever. 


\section{ANN SCHEIN}

From her first recordings with Kapp Records, and her highly acclaimed Carnegie Hall recital debut as an artist on the Sol Hurok roster, Ann Schein's amazing career has earned her high praise in major American and European cities and in more than 50 countries around the world. Since her debut in Mexico City in 1957 when she performed both the Piano Concerto No. 3 by Rachmaninoff and the Piano Concerto No.1 by Tchaikovsky, she has performed thousands of concerts on every continent. She has performed with conductors including George Szell, James Levine, Seiji Ozawa, James dePreist, David Zinman, Stanislaw Skrowacewski, and Sir Colin Davis, and with major orchestras including the New York Philharmonic, the Philadelphia Orchestra, the Los Angeles Philharmonic, the Baltimore Symphony, the Washington National Symphony, the London Philharmonic, the London Symphony, and the BBC Symphony Orchestra. Over her many years performing in London, she appeared repeatedly in the Promenade Concerts in Albert Hall. In 1980-81, Ann Schein extended the legacy of her teachers, Mieczyslaw Munz, Arthur Rubinstein, and Dame Myra Hess performing 6 concerts of the major Chopin repertoire in Lincoln Center's Alice Tully Hall throughout an entire season to outstanding reviews and sold-out houses, the first Chopin cycle presented in New York in 35 years. From 1980-2001 she was on the piano faculty of Peabody Conservatory, and since 1984 she has been an Artist-Faculty member of the Aspen Music Festival and School. In December of 2012, Peabody Conservatory honored her with a Distinguished Alumni Award, and she gave a recital in celebration of the event. ${ }^{90}$

\footnotetext{
${ }^{90}$ Biography taken from annschein.com (accessed February 19, 2016).
} 


\section{Where did you study with Munz and for how long?}

At Peabody Conservatory in Baltimore from 1953-1958 as a Special Student. Lessons and coaching continued privately through to 1970's.

\section{What were Munz's strengths as a teacher?}

Assessing each student individually and taking each one to higher artistic and technical levels. From his own vantage point as a world-renowned member of the Golden Virtuosos of the $20^{\text {th }}$ Century and having studied with Feruccio Busoni in Berlin, becoming his assistant at the age of 19, he had a feeling and a vision for the talents he believed could sustain a long career. To those, as well as to all of his students equally (a key to his integrity), he gave his full measure of time, work ethic, miraculous fingerings for varying sizes of hands, exercises from any work being studied which could enhance a student toward greater ease technically and often to breathtaking virtuosity. He emphasized using difficult passages in all styles and compositions as exercises with the confidence that the student could feel enhanced freedom at the keyboard and thus advance more quickly to a musical understanding of each work. He "pushed the envelope” encouraging performances under any circumstance to take risks in concerts, and he enjoyed watching each student's amazement at their newfound abilities under pressure to make music with released technical ease. He could see potential in each student for improvement. His virtuosity during his career of barely 20 years was legendary, as well as his poetic sensitivity as an artist. However, in the years I was with him, the 1950's, he could no longer perform or demonstrate, and he had the wise instinct to leave the student to his own imagination and creativity. He never dictated the "correct" interpretation. At times he would give his students fine recordings of great artists to help inspire them, but this innate belief in the musical talent of advanced students helped to bring out the individual voice of each one. He often used a 
repertoire class at Peabody to allow students spontaneous tryouts of new pieces as soon as he felt they could succeed well enough to give added confidence and growing musical understanding. He tested nerves under pressure often and cleverly. He did not talk much, and was at all times calm, confident, and gently kind. He never raised his voice or shouted at any of his students. His taste was impeccable and his quivering sensitivity palpable. He was a tender and reticent man, with an enormous smile of excitement when pleased. My parents loved and trusted him implicitly and with unflagging love and support they were with me every step of the way. Munz helped launch my career and was present at almost every concert I gave well into my 20's. He had become part of my family but lost none of his firm direction of my growth as a pianist.

\section{Did Munz recommend or favor particular technique exercises (i.e. Czerny,}

\section{Cramer, Hanon, Liszt, etc.)?}

He gave me Pischna and Busoni exercises as well as Etudes of Chopin, Moszkowski, Debussy, Scriabine, and Rachmaninoff, as well as a special routine for working on passages in each piece. This included repeated rhythmic patterns difficult to master, repeating small groups of notes twice, staccato and long note patterns, and in the Etudes of Chopin, demonstrating the most relaxed hand positions and correct motions for each one, resulting in greater flexibility and ease both practicing and in performance. These routines he would require his students to work on for a month or more before he allowed a trial run up to tempo. This took great discipline and patience and developed a lifetime of possible solutions to working out technical difficulties and effective practice habits. Scales were always recommended, often in contrary motion and never with tension or excess speed. He watched for any sign of tension in lessons in the muscles, at times coming up behind a student and throwing their arms in the air to test their looseness. If 
and when he had any nerves for you during a performance, he never showed it. He kept the challenges pushing each student gently but firmly, eagerly watching their progress. He demonstrated deep humanity, empathy and sweetness, peppered with jokes and pieces of candy as rewards. He was a rare and poetic nature, whose own life became a tragic story resulting from the ravages of World War II when he lost his entire family, his parents and 23 members. Then came the loss of his wife to another man, and eventually through nervous collapse caused by these mounting events, the loss of his ability to perform. It was the miracle for his students that he was able to give so much to them and invest in their own future so selflessly.

\section{Which repertoire or aspect of performance do you feel you learned the most}

\section{about from Munz?}

Of course the Polish legacy of Chopin's music came immediately from him to his students. While I was at Peabody, I was given 18 of the 24 Etudes, and performed 12 of them at the age of 15 at the Phillips Gallery in Washington, D.C. and recorded several of them for Kapp Records from 1958-61 including the $2^{\text {nd }}$ Concerto in F minor. His friendship and admiration for Rachmaninoff as a man, artist, and consummate pianist I suppose motivated his giving me Etudes, Transcriptions, and Concertos of Rachmaninoff during those years, specifically the $3^{\text {rd }}$ Concerto and the Rhapsody on a Theme of Paganini. My first performance of the $3^{\text {rd }}$ Concerto took place at Peabody when I was 16. There have been over 100 since then in more than 40 countries thanks to his painstaking and solid teaching while learning it, and his allowing me to "launch" an early performance at Peabody where I finished the last page measures ahead of the orchestra! He gave me the two pinnacles among Beethoven Sonatas, the Waldstein and the Appassionata around the same time (plenty of hard passages to practice in all those works

enhancing my entire technical command, plus both the $4^{\text {th }}$ and $5^{\text {th }}$ Concertos asking me to push 
memorizing both of them in just 4 weeks. I performed the Emperor Concerto with the Washington National Symphony in my early 20's, to beautiful reviews, especially noting the "heavenly slow movement". It was played as "the noble monarch", said the critic. This was a great demonstration of Munz's lack of emphasis on the merely technical difficulties so formidably present in the Emperor, and his impeccable artistic guidance. He also gave me the Schubert "Wanderer Fantasie" very early in my studies with him. I learned it and practiced its formidable passages during the first summer with him in Mexico City, where he took his vacations. He gave me a lesson every day for several months and practiced with me, teaching me how to work at a far more intense level and for longer hours. This was the depth of his trainingOlympic is how I describe it - during two whole summers until my debut in that city in 1957, with the $3^{\text {rd }}$ Rachmaninoff and B-flat Tchaikovsky Concertos one week apart followed by a recital. I was 17, and he made the whole event seem like a normal schedule. Some of the additional repertoire Munz gave me were works of Bach, Haydn, Beethoven, Mozart, Scarlatti, Brahms, Schumann (major influence), Granados, Albeniz, Debussy, Ravel, Scriabine, Liszt, and Bartok.

\section{Were there particular pianists Munz recommended or preferred?}

Yes. Among them were Horowitz, Wilhelm Bachaus, Godowsky, Busoni, Josef Hofmann, Rachmaninoff, Josef Lhevinne and Claudio Arrau. Later came Gilels, Richter, and he recognized the amazing gifts of Martha Argerich very early in her career. He would have loved Perahia, Kissin, and walked out of Lang Lang! Arthur Rubinstein he always admired, with a personal hesitation to speak about him or attend his concerts due to Rubinstein causing Munz's wife to divorce Munz and marry Rubinstein in the 1940's. Munz never recovered emotionally from this, but was deeply moved when Emanuel Ax, Munz's student from early teenage, won the $1^{\text {st }}$ Prize in 
the first Rubinstein Competition in Israel. He was very happy to have Rubinstein take an interest in my own playing and career, therefore, “approving of Munz’s teaching and artistic guidance”, when Rubinstein first heard my recording of the $3^{\text {rd }}$ Rachmaninoff. Rubinstein then "sent for me" to play for him. On hearing that my teacher was Mieczyslaw Munz, Rubinstein requested Munz's presence as well at that first meeting in 1961. Rubinstein and Nela were present in Carnegie Hall for my debut in 1962, and their relations with Munz were restored to a polite cordiality.

There are no words adequate to describe the gratitude for such a teacher, mentor, and extended family member. Looking back and realizing how much he gave to all of his students and how much he believed in ensuring "a long life in music”, I consider him to be a miraculous gift in my life, enabling me to reach the age of 76, still performing the music he taught me so long ago.

\section{ROBERT SWAN}

Robert Swan is a successful concert pianist whose artistry has created an internationally renowned career, bypassing the traditional competition circuit. Even before his solo recital debut in Alice Tully Hall at Lincoln Center in New York City and London’s Wigmore Hall, he was performing as recitalist and soloist with major orchestras throughout the United States. In all, Dr. Swan has performed 22 different concerti — across America, at the White House, and in England, Taiwan, and Korea. Born in Pennsylvania, he began piano studies at age 5. While a young teen, he gave his orchestral debut with the Juniata College Symphony performing Mozart’s A Major Piano Concerto K. 488. Dr. Swan earned his bachelor of music degree from the Eastman School of Music, his master of music degree from the Julliard School, and a doctor 
of musical arts degree from the University of Arizona. His major teachers include American pianists Earl Wild and Eugene List, Polish pianist Mieczyslaw Münz, and the distinguished French pianist Paul Doguereau. While serving in the U.S. Army during the Vietnam era, he was a bandsman stateside and performed on electric piano with Dean Martin’s Golddiggers. He also served overseas. Dr. Swan taught at Turtle Bay Music School (a community music school) in New York City and held a two-year teaching assistantship while working on his doctorate at the University of Arizona. Currently, he is an instructor of piano at Seattle Pacific University and teaches at Music Works Northwest (a community music school) in Bellevue, Washington. Active as an adjudicator and educator, Dr. Swan is on the International Baldwin Artist Roster. ${ }^{91}$

\section{Where did you study with Munz and for how long?}

The Juilliard School for 2 years.

\section{What were Munz's strengths as a teacher?}

Good fingerings, demanded accountability in all aspects of artistry.

3. Did Munz recommend or favor particular technique exercises (i.e., Czerny, Cramer, Hanon, Liszt, etc.)?

No. I did not need it. I got it from the music.

4. Did Munz create specific technique exercises which you learned from him? If so, could you describe them and for which works, if any, these exercises were intended?

If exercises occurred, it was from changing the rhythm and notation.

\footnotetext{
${ }^{91} \mathrm{http}: / /$ spu.edu/academics/college-of-arts-sciences/music/faculty-staff-directory/swan-robert (accessed March 4, 2016)
} 
5. Did Munz teach a particular routine or have a specific approach for scales, chords, and arpeggios?

No

6. What do you consider the most important concept you learned from Munz that has stayed with you in your own teaching?

Memorization - No. Technique practice was by altering the notation of rhythm.

7. How would you describe Munz's approach to developing students' interpretive abilities?

He did not demonstrate at any lessons.

8. Which repertoire or aspect of performance do you feel you learned the most about from Munz?

To accept only the best technical and musical performance.

9. How would you describe Munz's approach to developing students' interpretive abilities?

Learn the music with a flawless technique for the interpretation.

10. Which repertoire or aspect of performance do you feel you learned the most about from Munz?

I studied Rachmaninoff, Liszt, Chopin, Bach, Beethoven, and Brahms.

11. Were there particular pianists Munz recommended or preferred?

No discussion as such. 


\section{Is there anything else you would like to add about Munz and his teaching and}

artistry?

Mr. Munz accepted nothing less than the best of piano playing. He used Blue and Red pencils to emphasize places not yet ready for performance. He did not waste a minute in a lesson. I remember he said, "It takes something more than endless hours of practice and years of study to be a concert pianist.”

\section{STEFAN YOUNG}

Stefan Young is professor of theory and composition at Westminster Choir College of Rider University. His music studies began with his parents, Raymond and Ruth Young, and continued with Edwin Hughes, Thomas Brockman, Nadia Boulanger, jean Casadesus, Robert Casadesus, Annette Dieudonne, Mieczyslaw Munz, Robert Moevs, and Rolv Yttrehus. He received a B. M. from Rollins College; certificate in harmony, piano, and solfege from The American School of the Arts, Fontainebleau, France; an M.M. in piano from The Juilliard School, and a Ph.D. in composition from Rutgers University. He has won numerous honors and awards. He has composed for various media, including orchestra, band, choir, chamber ensembles, voice and piano, and a variety of solo instruments. ${ }^{92}$

\section{Where did you study with Munz and for how long?}

The Juilliard for two years.

\footnotetext{
${ }^{92}$ Stefan Young, biography http://www.rider.edu/faculty/stefan-young (accessed March 10, 2016)
} 


\section{What were Munz's strengths as a teacher?}

He was very particular about fingering. He would have me put my fingering ideas into the score. He then would observe these as I played and correct what he felt were weak choices. His preference seemed to emphasize using the stronger fingers if possible. This was helpful in some Etudes Tableaux of Rachmaninoff. In one broken chord passage in Beethoven's D major sonata Op. 10, No 3 the last movement (rondo) a descending V7 chords leading to a fermata (the last page). I had used the fourth finger in the pattern- he replaced this with the 3rd finger all the way and it became much easier. In Ondine from Gaspard de la Nuit he re-arranged some right hand passagework to be shared between the hands which greatly increased the smoothness of the physical delivery. Also his demonstrations at the other piano were lovely. His tone was beautiful and something all students would want to emulate. (I see this answers no. 7!) His fingering suggestions helped with this tonal sensitivity.

3. Did Munz recommend or favor particular technique exercises (i.e., Czerny, Cramer, Hanon, Liszt, etc.)?

No

4. Did Munz create specific technique exercises which you learned from him? If so, could you describe them and for which works, if any, these exercises were intended?

No

5. Did Munz teach a particular routine or have a specific approach for scales, chords, and arpeggios?

No 
6. What do you consider the most important concept you learned from Munz that has stayed with you in your own teaching?

Color and fingering (as above).

7. How would you describe Munz's approach to developing students' interpretive abilities?

He was very particular about dynamics and was looking for finesse, not brute force!

8. Which repertoire or aspect of performance do you feel you learned the most about from Munz?

The above!

9. Were there particular pianists Munz recommended or preferred?

Not to me.

12. Is there anything else you would like to add about Munz and his teaching and artistry?

Very gentlemanly and encouraging. 


\section{CHAPTER III}

\section{CONCLUSION}

Today, Munz ranks with those few who are recognized as the great masters of the art of pianoforte playing Munz is to be added to the list of pianists of the first rank; there are not many, but he is undoubtedly one of their number. ${ }^{93}$

- The San Francisco Examiner

Pianist Mieczyslaw Munz was one of the outstanding representatives of the Golden Age of the Virtuoso. Critics worldwide acclaimed his performances, with his artistry praised for the warmth of feeling and admirable technique, delightful delicacy, poetry and precision. With the end of his public performances in the early 1940s, his enthusiasm for music turned into devotion to his students. He approached his students individually, crafted an approach instilled with encouragement and firm belief in their talent and potential. His pure love for music, shown in his highly acclaimed performing career, became an unselfish, sacrificing devotion to his students.

After his formal debut in Berlin, Munz began a prominent career as a concert pianist, performing throughout the world including America, Europe, and Asia. Munz’s performing career ended due to injury of his right hand. This and the other losses he endured were truly tragic. When he found himself at the bottom of his troubled life, it was music that helped him to regain it. With the help from many sincere friends who truly appreciated his talent, and in particular the compassion and respect of Reginald Stewart, he rebuilt his life and lived the second chapter as a distinguished teacher. He could not recover his genius as a concert artist, his family did not come back, and he never found another woman to share his life, but his artistry

${ }^{93}$ Quoted in Brochure of The Mieczyslaw Munz Scholarship Fund, Inc. 
carried on through his students and he built a musical family with many pupils considering him a father figure. Music brought back in a new form so much of what he lost.

As a teacher, many of Munz's most outstanding characteristics serve as a model for teachers today: the respect of the student; the high standards; the individual assessment of each student's needs; the generosity of time and resources; the healthy technique; the noble character; the problem solving abilities; the overall caring, familial, and sympathetic nature; and the concern for the student's future beyond studies. These are just some of the traits which have been passed on to his students and likewise for generations to come.

Munz did not teach students with repetitive routines or pre-formed methods. Instead, he approached students individually to help them to find their own styles and develop their own interpretations. He even graciously allowed his students to work with other renowned pianists, sometimes even setting aside his own personal needs for the student. His approach to his students was individually unique and yet collectively warm and gentle, which may be the reason why many of his students felt him to be their musical "father.” It seems he was particularly gifted in finding the weaknesses and strengths of each student while very patiently encouraging them. Even though Munz himself could no longer perform, his students’ performances reveal his artistry. His emphasis on tonal sensitivity, ingenuity in fingering, and healthy technique were hallmarks of his teaching that all of his students recalled and still serve as an inspiration.

Munz had a vast recital repertoire including the standard masterworks such as Schumann, Chopin, Brahms, Beethoven, and Bach, as well as transcriptions by Liszt, Busoni, Tausig, Godowsky, Dohnanyi, and his own. His repertoire demonstrated the variety, as well as his virtuosity. It is unfortunate that he had very few recorded performances. His only CD, entitled The Art of Mieczyslaw Munz was released posthumously in 2002 featuring live concerto 
performances, six preludes by Chopin, and various short works, several being virtuosic transcriptions recorded from the historic piano rolls. His recording bring us his highly sophisticated musicianship: sparkling, feathery finger work; sensitive, poetic, phrasing; and an overall effortless, elegant style.

Munz will be appreciated and cherished for the impeccable artistry of the few recordings that do exist and the way he enriched piano performance and study through countless students whose own careers have brought great music to so many around the world. Munz is an artist whose name and legacy deserve to be long remembered not only by his students, but also by the public, which continues to enjoy the consummate artistic truths he so generously shared. 


\section{APPENDIX A \\ Timeline of Events in the Life of Mieczyslaw Munz}

1900

1909

1912

1914

1919

1920

1922

1923

1924

1924

1924

1922-1942

1925-1930

1930-1932

1930-1933

1938

1940

1941

1941-1942

1942

1946-1964

1946

1962-1963

1964-1976

1965

1967

1975

1976
Born in Krakow, Poland on October 31

Enrolled in the Krakow Conservatory

Performed the Tchaikovsky Piano Concerto No. 1 with the Krakow Symphony Orchestra

Studied at the Vienna Academy of Music

Went to Berlin to study at the Hochschule für Musik with Ferrucio Busoni

Made legendary debut in Berlin performing three concertos in one night

Made New York debut in Aeolian Hall

Soloist with New York Symphony Orchestra

Concerts, Mieczyslaw Munz Season at Town Hall, Melbourne in August

Concerts, Mieczyslaw Munz Season at Town Hall, Adelaide in September

Performed 5 nights straight at Imperial Theatre in Japan

Performed throughout Europe, the United States, Asia and South America

Taught at the Cincinnati Conservatory in Ohio

Taught at the Curtis Institute of Music in Philadelphia

Taught at The Peabody Institute of Music, Baltimore

Performed Town Hall recital in New York

Performed with NBC Symphony Orchestra and at the White House

Performed in Carnegie Hall with National Orchestral Association

Full faculty member at The Curtis Institute of Music

Stopped performing career due to hand/arm problems

Full faculty member at The Peabody Institute of Music

Became naturalized United States citizen

Taught at Manhattan School of Music

Professor at The Julliard School

Master Class in South Korea

Master Class in South Korea

Visiting Professor at Tokyo National University

Died on August 26 in New York 


\section{APPENDIX B}

\section{Selected Concert Programs (1919-1942)}

Program \#1: 1919 in Poland

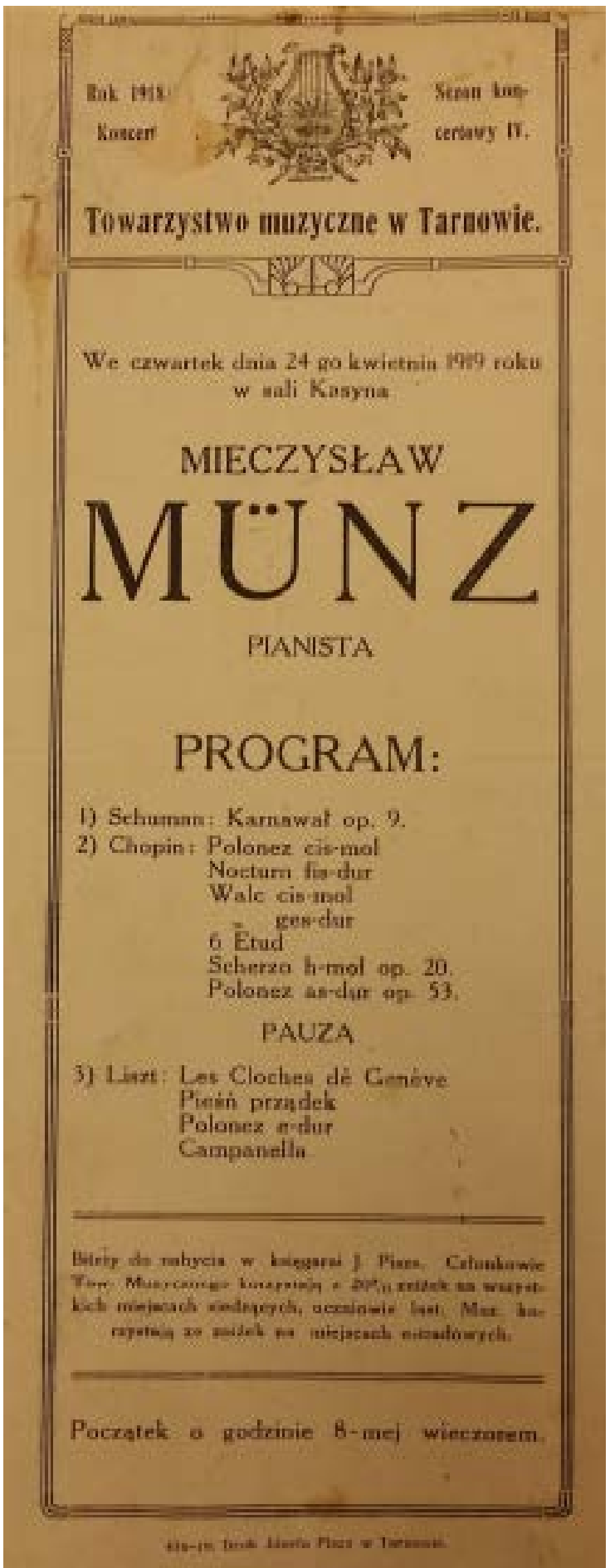


Program \#2: 1919 in Poland with Lódzka Symphony Orchestra

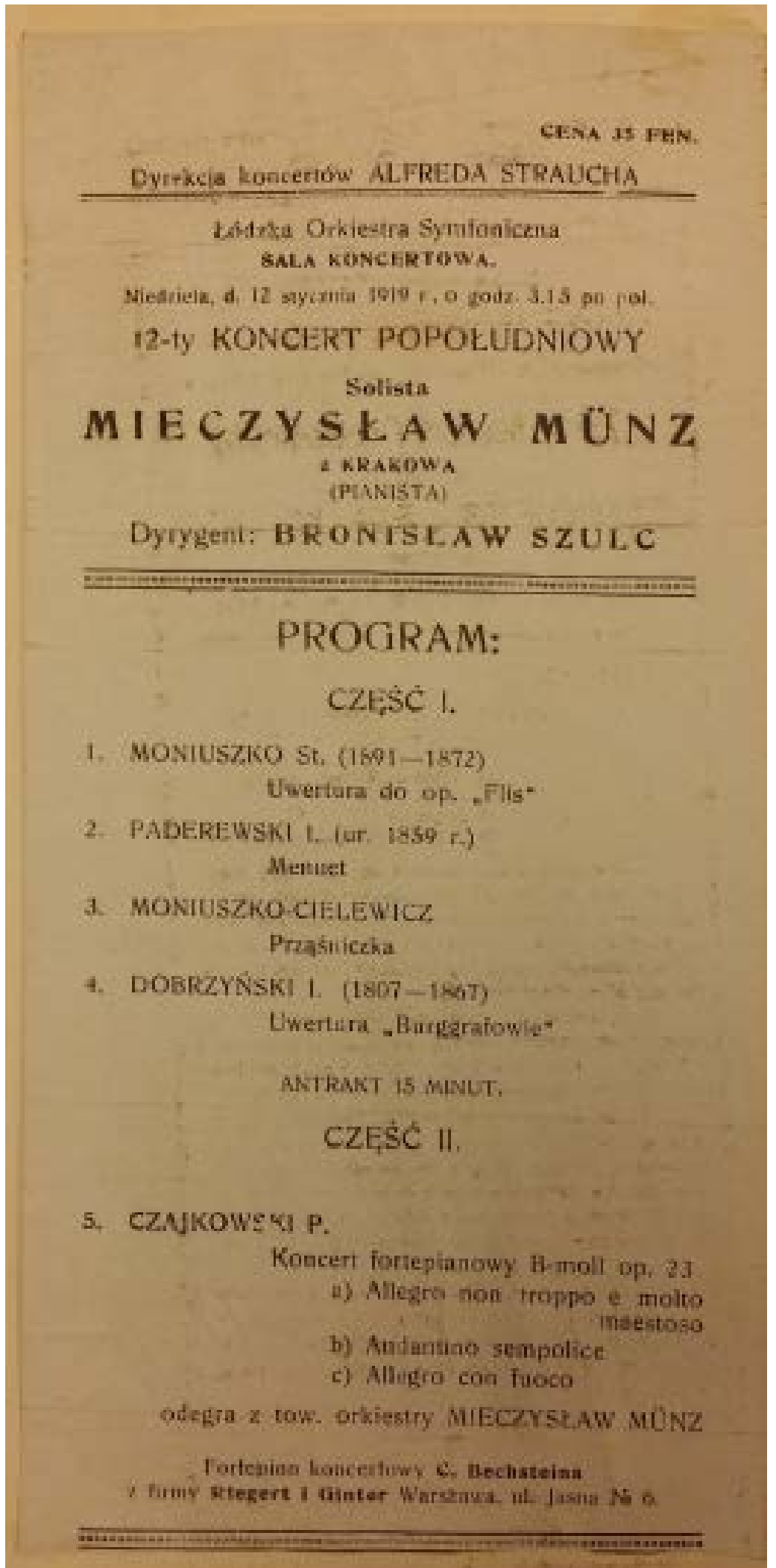


Program \#3: Season concert in 1919-1920, Poland with Lódzka Symphony Orchestra

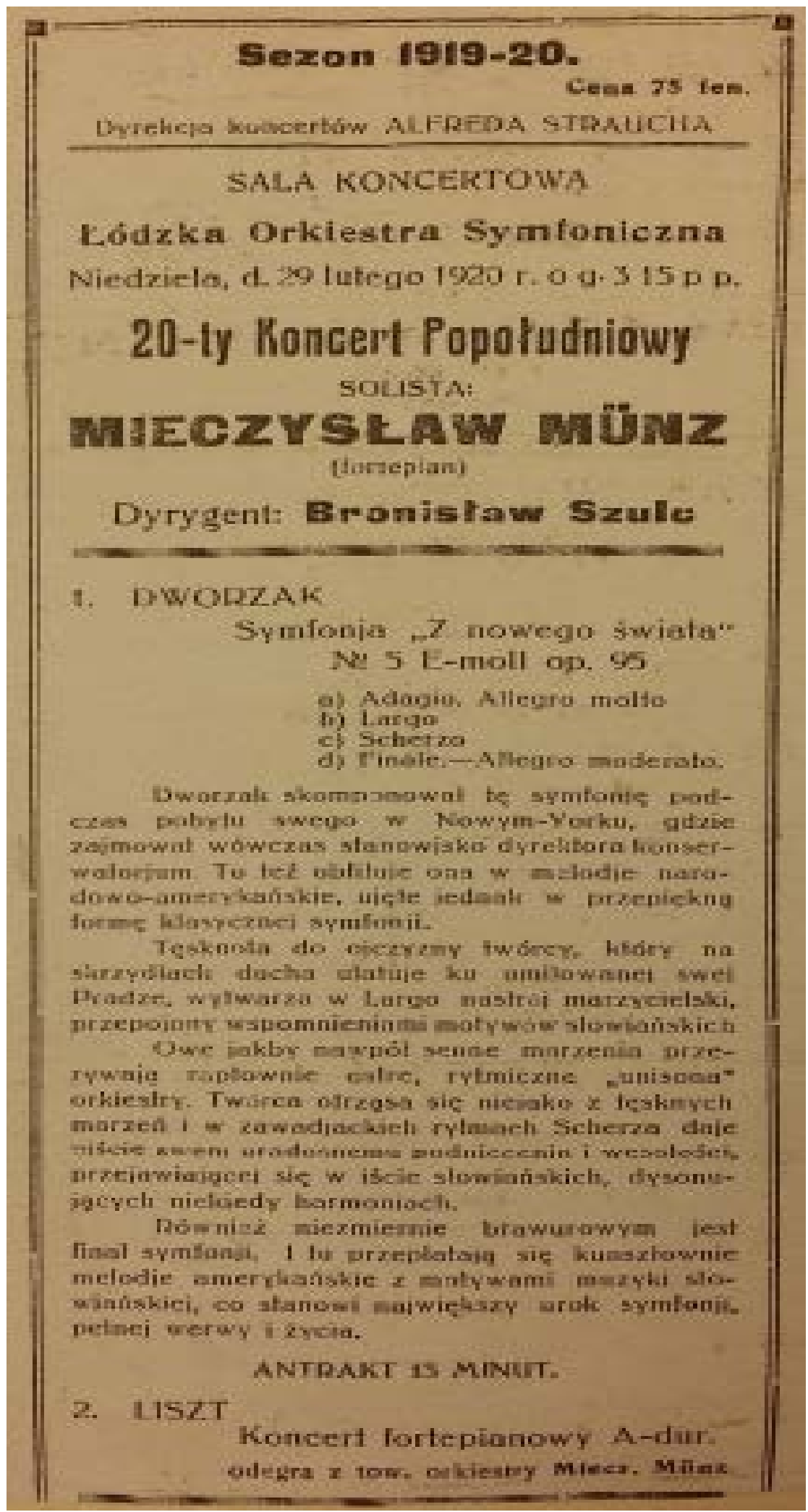


Program \#4: Solo recital at National Office Concert Theatre in Poland, 1920

\section{KRAJOWE BIURO KONCERTOWE I TEATRALNE}

We wtorek, dnia 3 lutego $1920 \mathrm{r}$.

\section{MIECZYSKAW}
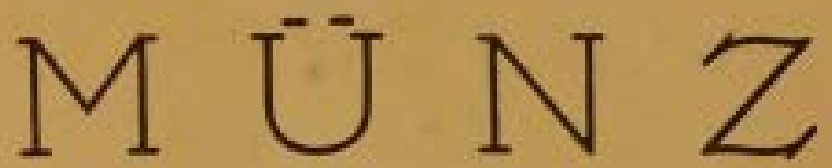

\section{PROGRAM:}

\section{F. LI5ZT; 1. Warjacje na lemat kantaty Bocha: \\ Welnen, Klagen, Songen, Zosen. sind des Christen Thranernbcods. \\ 2. Sonara H-moll \\ 3. Loreley \\ Les clochos de denere \\ 4. Legenda A-dur \\ Etuda F-moll \\ Parafraza walca $z$ mauston.}

Daczotek 0 godzinle \& wieczarem.

pouza po drugim numerze.

$Z$ kencern Marce

14. RECITAL MIECZYSLAWA MUNZA

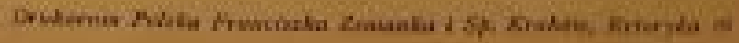


Program \#5: Solo recital at Sala Kasyna in Poland, 1920

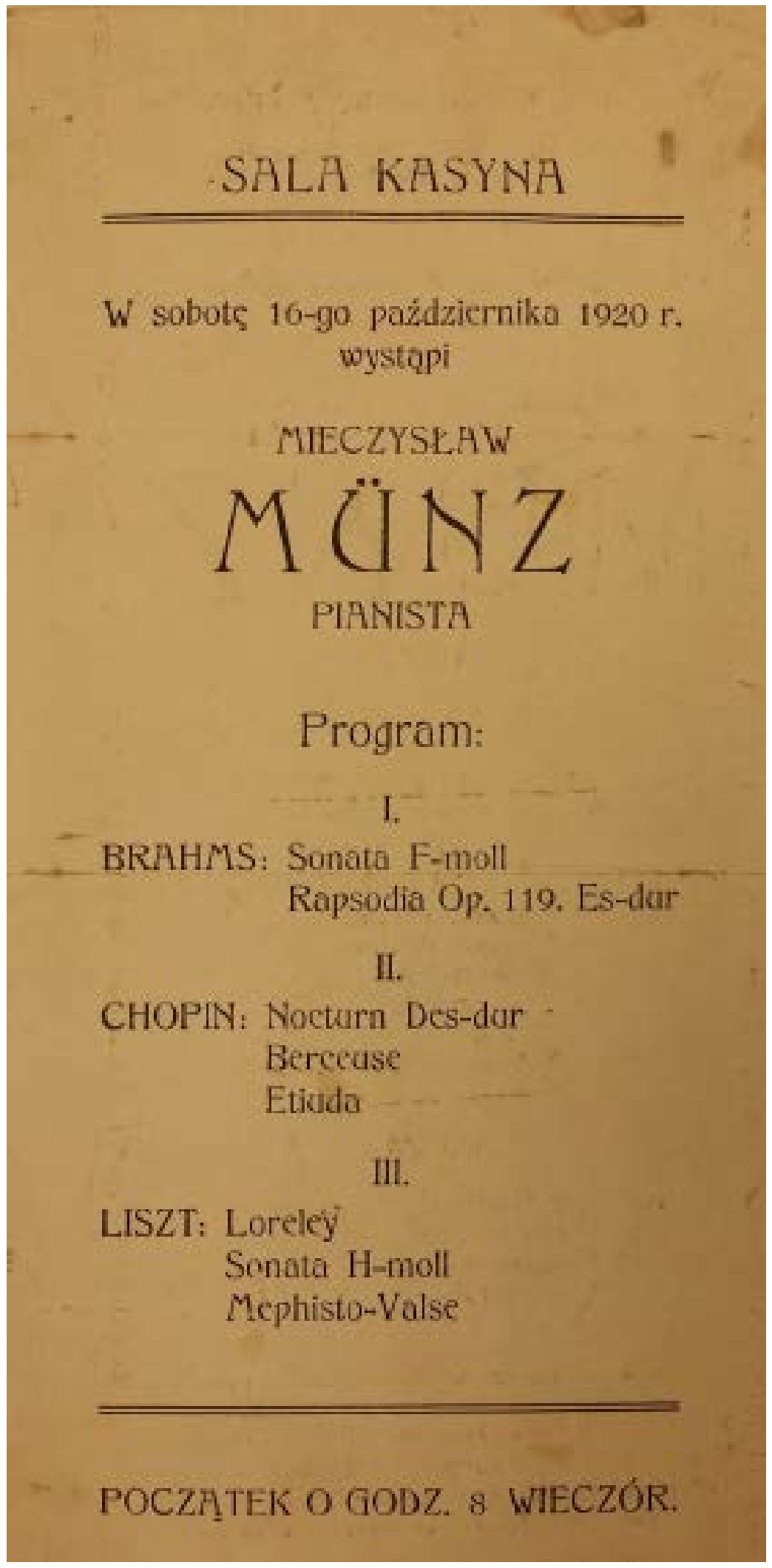


Program \#6: Recital at Tow. Muzycznego Concert Hall in Poland, 1920

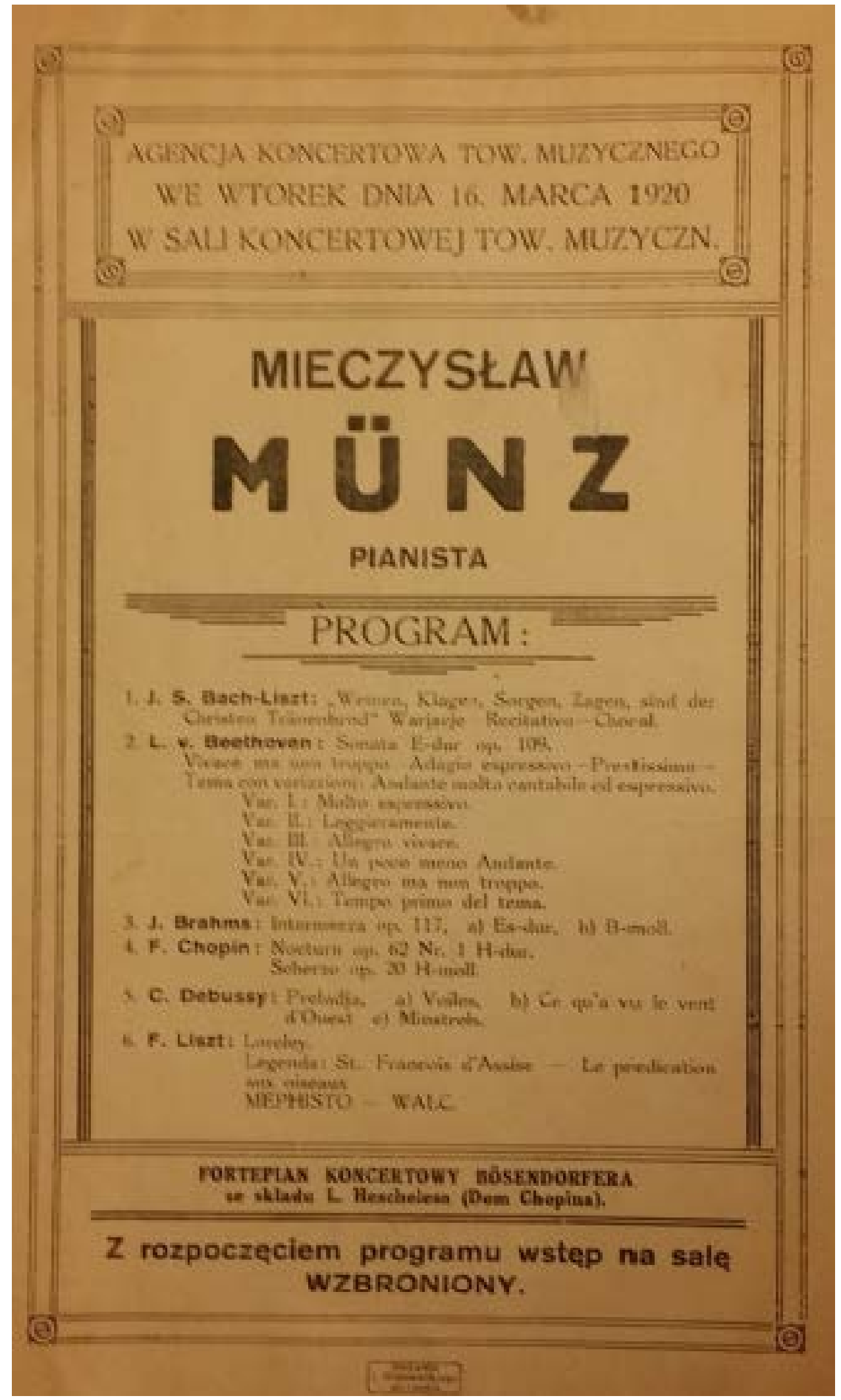


Program \#7: 1921 in Berlin

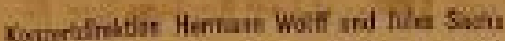

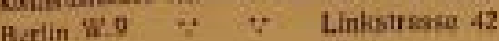

Preis $80 \mathrm{Pfo}$.

Kothenerstr. 32

Beethoven -Saal

ㅁㅁ뭉

Kölhenersir, 32

Freitag, den 16. September 1921

aberads $71 / 9$ Lbr

I. Klavier Abend

Mieczyslav Münz

spio

1. Bach-Liszt: Variationen über die Kantate „Weinen, Klagen, Sorgen, Zagen"

2. Beethoven: Eroica-Varialionen und Fuge op. 35

3. C. Franck: Prélude - Aria - Finale

4. Liszt: a) Bénédiction de Dieu dans la solihde Schubert-Liszt: b) Erlkönig

5. Paganini-Liszt: Etuden
a) Es-dur - Andantino capriccioso
b) E-dur - La chasse
cl Gis-moll - La Campanella

Konzerfllïgel: Bechstein

Wahirend der Vorträge bleiben die Saattiren geschlosaen 
Program \#8: Concert Program in 1921

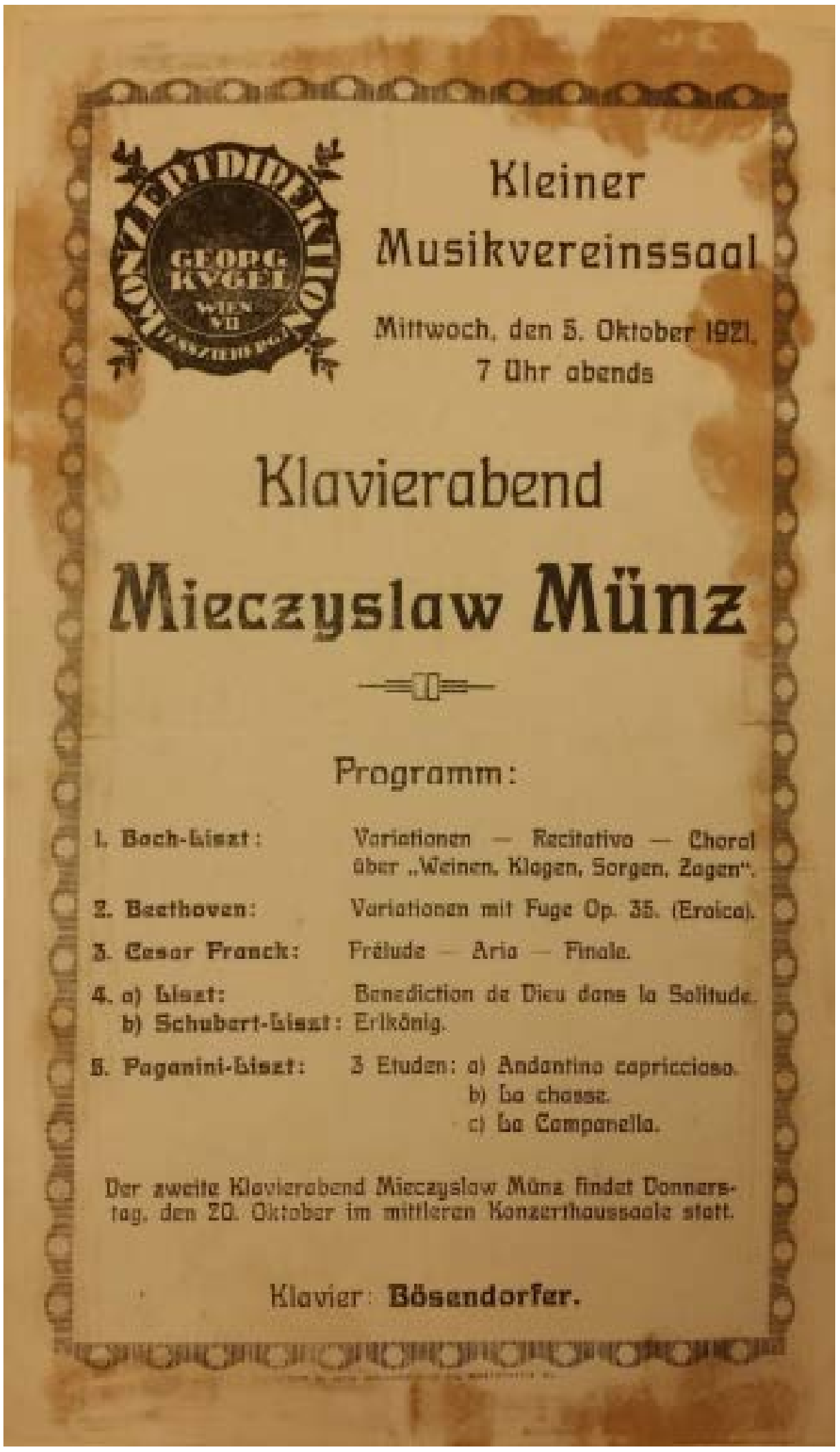


Program \#9: Concert with Blüthner Orchestra in Berlin, 1921

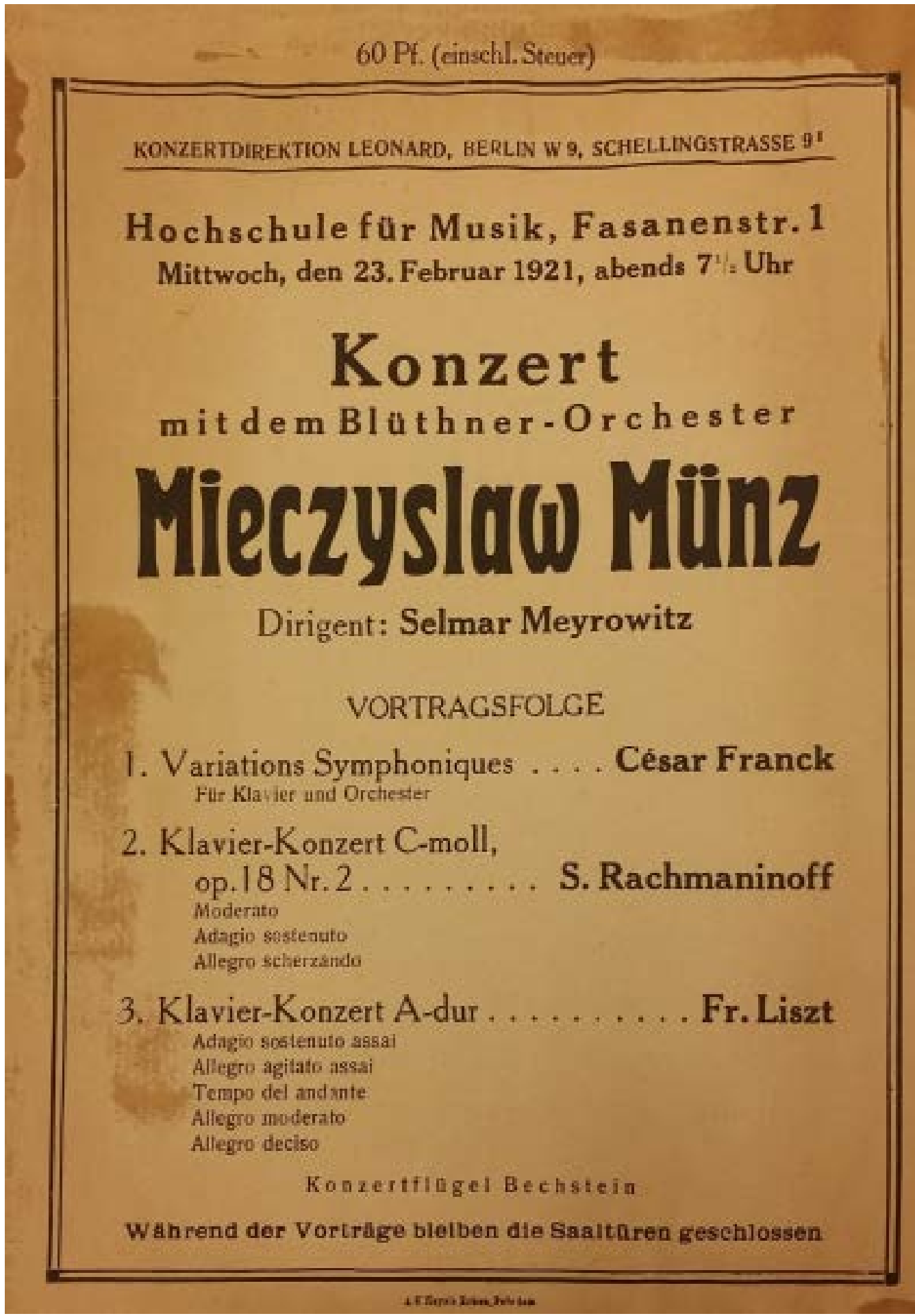


Program \#10: Cover page of Solo Concert at Sgambati Hall in Rome, 1921

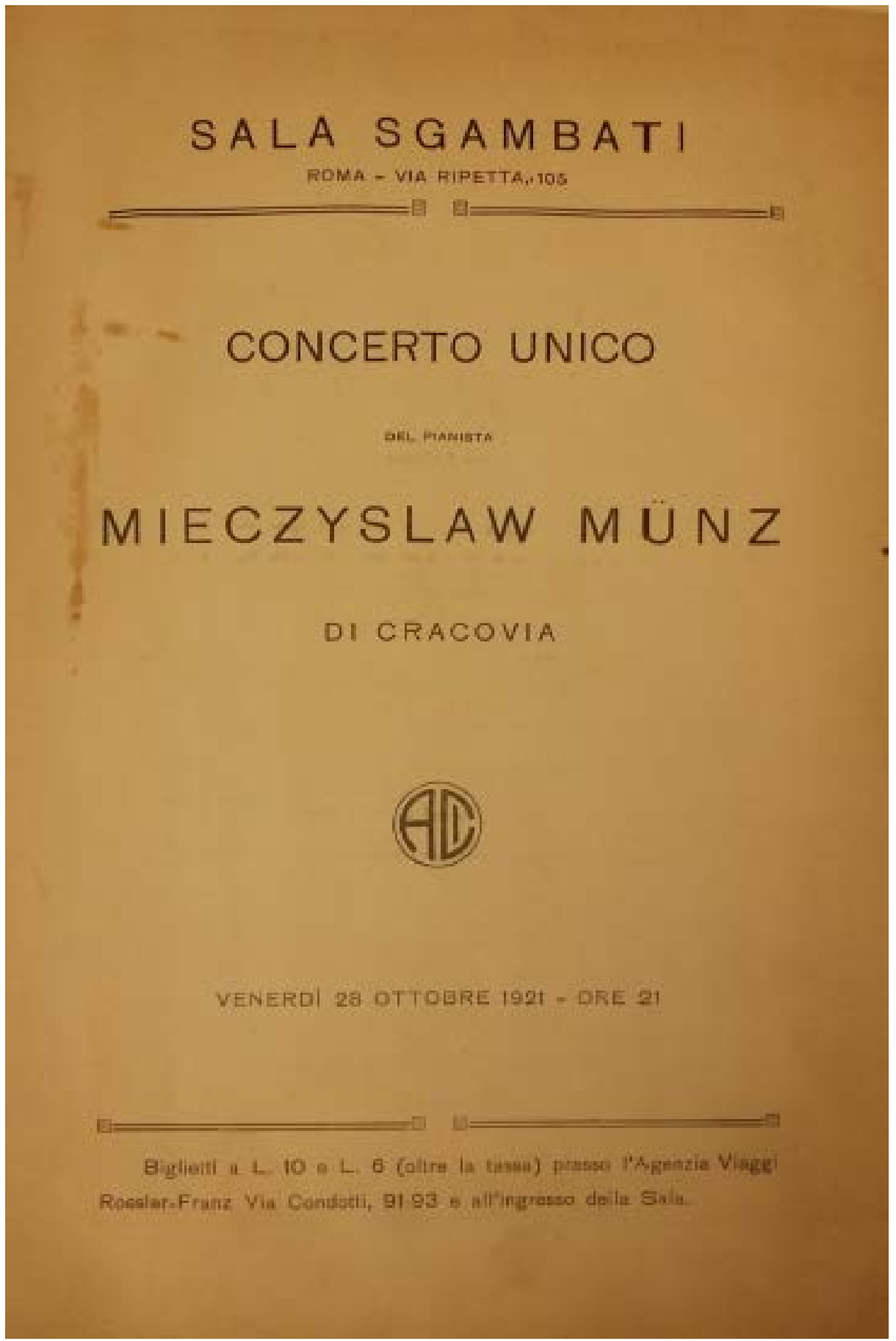


Program \#11: Program of Solo Concert at Sgambati Hall in Rome, 1921

\section{PROGRAMMA}

1. BRAHMS - Sonata op 5.

2. BEETHOVEN - Variasioni e Fuga op 35.

[Erom:

3. LISZT - Bentidiction de Dien dans la solitude. SCHUBERT-EISZT - EVlhinig

PAGANINI-LISZT - Andantino capriccioso.

La caccia.

La campanella.

4. STRAUSS-TAUSIG - Nachifalter.

(2) வீ

จุ

PIANOEORTE BECHSTEIN 
Program \#12: Recital at Aeolian Hall in New York, 1922

sis.

AEOLIAN HALL

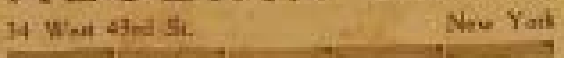

FRIDAY EVENING

OCTOBER 20 th

ut S.13 extark

PIANORECITAL

by

MIECZYSLAW
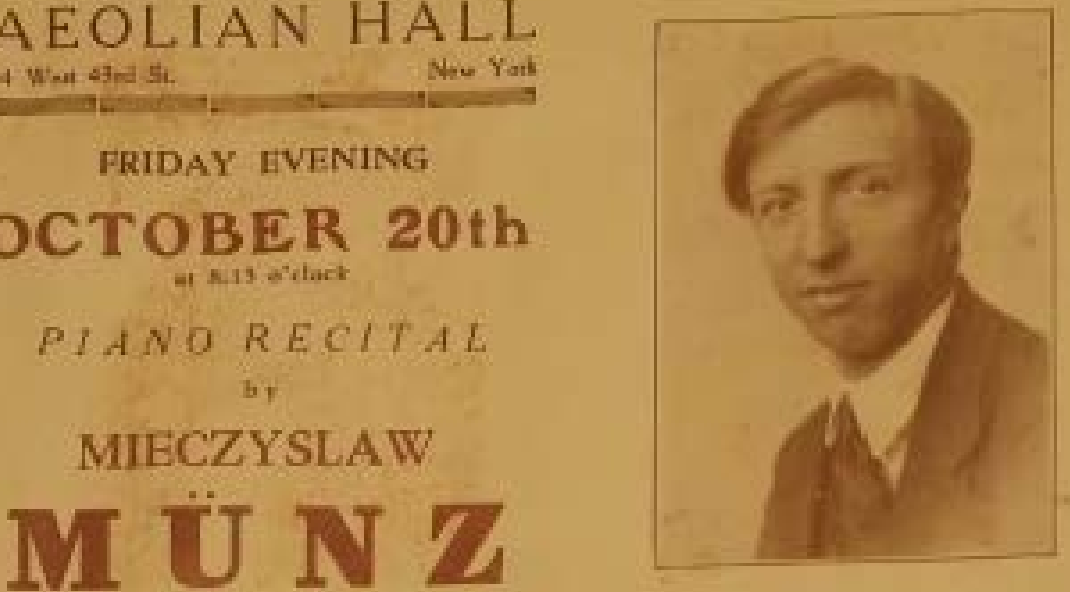

Jiragramua:

I.

Vacastions on a Theose, and Chatal fram the Cantata

"Weinen Klogen.Sugken-Zagen" [arr-by Lisn]

"Weinen Klagen.sergen-Zagen"

Bach Menues [firat time]

n.

Prelade-Aria-Einale

Dactor Gridus of Purnissum

Pselode $G$ strarp mitue

Lieleafreud [firat time]

Debuss

Ractumaninolf

Xitulet.Muirs

Erude, Op 10 , in $\mathrm{C}_{\text {majar }}$

N. 12 in $C$

Nocturne, C Majot

Two Mamurasas

Chapin

III.

Cbopis

Chopia

IV.

Nachifalere

KNARE PJANO USFD

AUPCO RECONDS

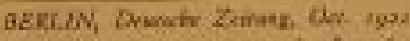

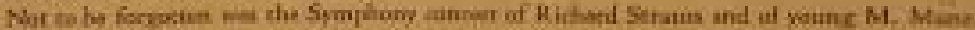

PIENNA, Wdibien, Now igat

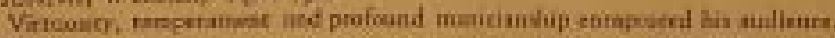

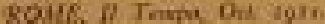

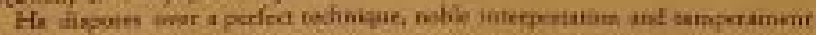
WABSAW, Ensing Pout, Fin byen.

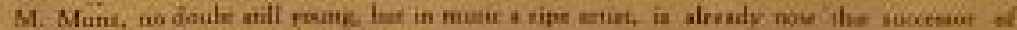
Rubissirin, Hotemani and Frielmat 
Program \#13: Second Piano Recital at Aeolian Hall in New York, 1922

\section{AEOLIAN HALL

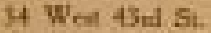 \\ THURSDAY BVENING \\ DECEMBER 7th \\ it 4 is welork}

SECOND PIANO RECITAL

by

MIECZYSLAW
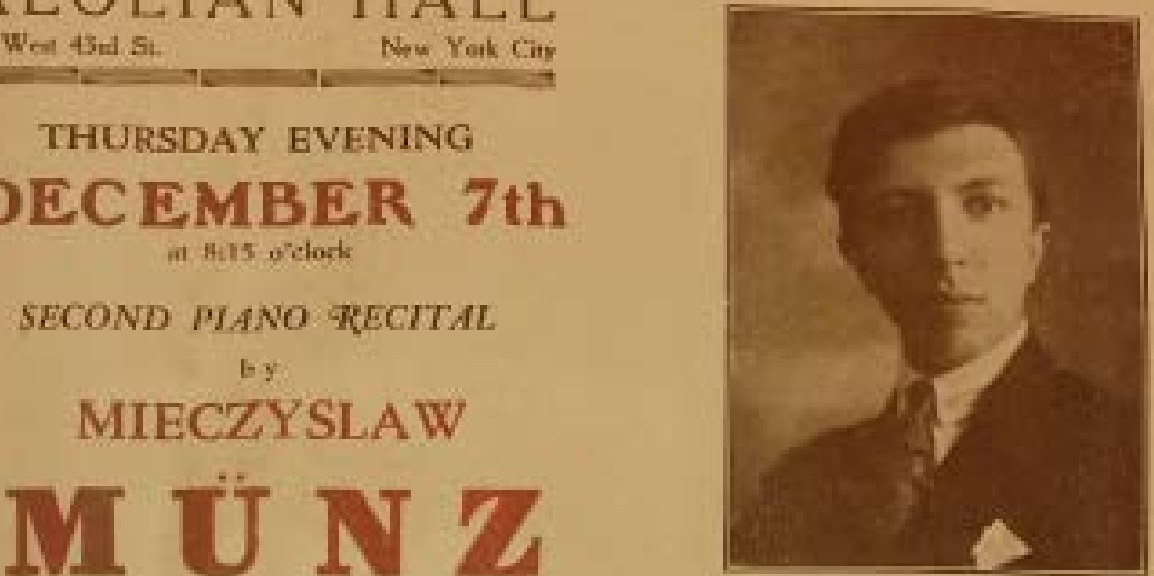

Jjrograumat:

I

Sonate, Op., , F miner

Brahma

Allego neeitions

Andaute 'Mstio'

Der Abead danement,

Pu Moadliste whein.

D. und ewei Hetern

In Litie meriat

Scherza

Und halien sch oflie unfasere.

Iriteraens

Finale:

"Eterica" Variations with Fague, Op, 35 II.

- Beethorea

La Cathedrale engloutie

La fille alax cheveux de in

Debussy

Debusny

Movements perpetuels

Frabcis Poulenc

Tabatiene a musique.

IV.

Frindman

Masuitka, A minot

Chooin

Pelonaise, A flat insjor

Chepin

KNABE TIANO USED

AMPICO FECONDS

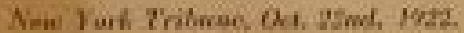

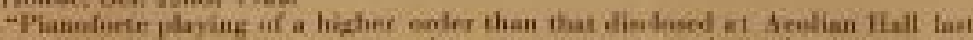

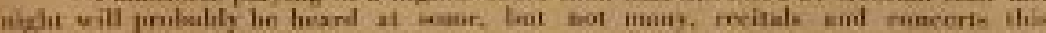
wasen." fi. $F$ Nrwhiet.

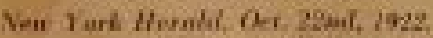

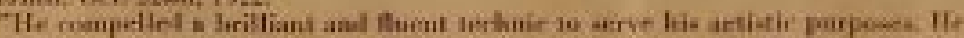

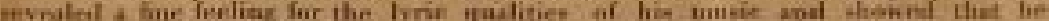

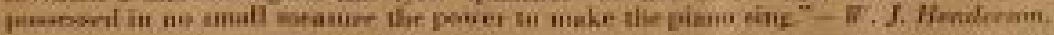

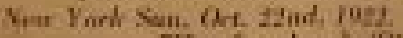

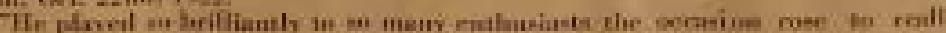

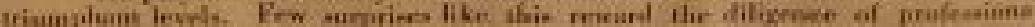

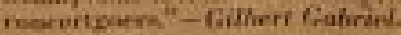


Program \#14: Advertisement for the Concert with New York Symphony Orchestra

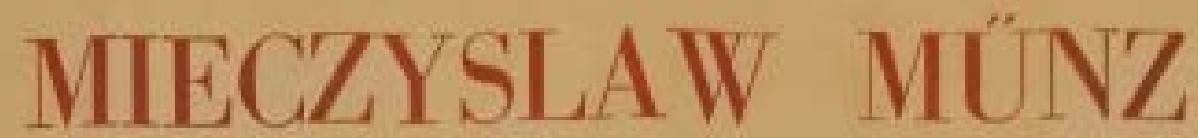

SENSATIONAL POLISU MIANIST

THIS SEASON APPEARED AS SOLOIST WTTH

NEII YORK SYMPIIONY ORCIIESTRA

imaler

D A M R O S C H

(IISZT A MAJOR CONCERTO)

NEIV YORK SYMPHONY ORCHESTRA

under

$\theta 0 A$ त

(CETSAR FRANCK VARIATIONS SYMPHONIQUES)

NEII YORK PHILHARMONIC ORCHESTRA

under

MENGELBERG

(RACHMANINOFF C MUNOR CONCERTO, No. 2)

AMPICO RECORDS

KNABE PIANO

Exclusive Management HAENSEL \& JONES

Aentinen Halt, N. Y. 
Program \#15: Concert with New York Symphony Orchestra at Aeolian Hall in New York, 1923

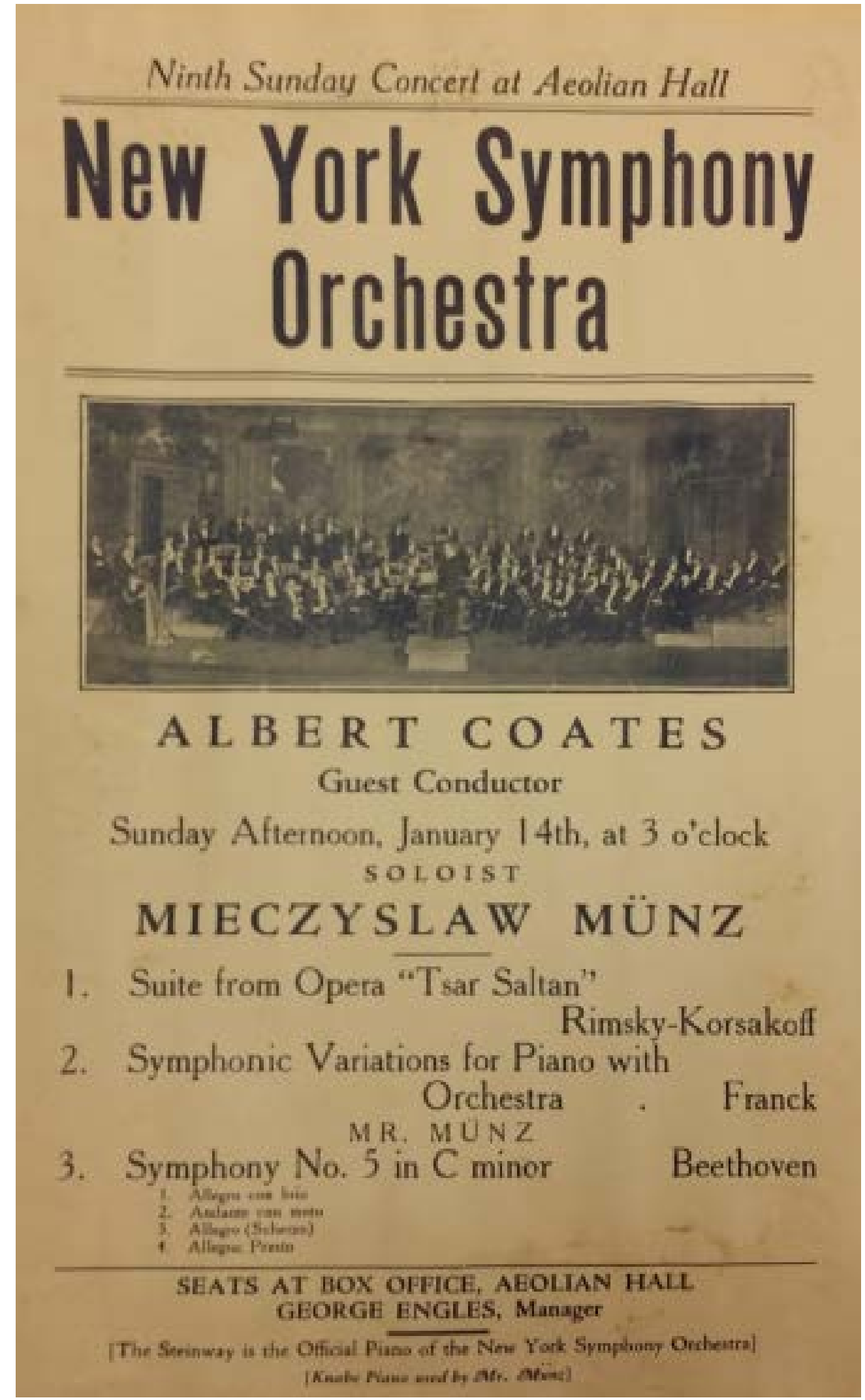


Program \#16: Recital at Carnegie Hall in New York

CARNEGIE HALL

Sith Strent of fib Ave.

New Yoh City

Friday Evening

$$
\begin{aligned}
& \text { A) 8:15 pielork } \\
& R \in C i t a l
\end{aligned}
$$

B y

MIECZYSL,AW

M
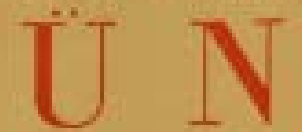

POLISH PIANIST

\section{OCTOBER 22nd}

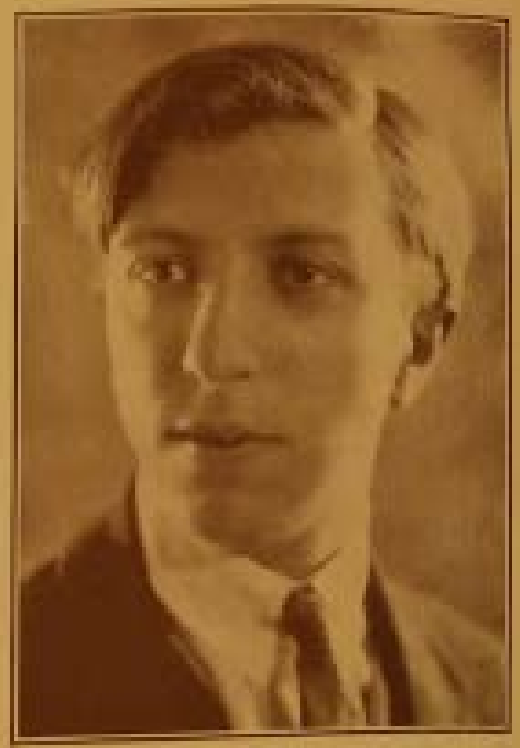

PROGRA M:

I.

Six Sonatas

Senrinti

II.

Fantasir in C Major. Op. 17 Schumartn

III.

Menuet

(Vint Time!

f.aburnali

Three Fairs Tales Movituer

Impromatu Fanar

IV.

Noeturne

Two Etudes

Cifopin

Tarantelle

KNAME MINO

Mnovgrewerint;

HAENSHI \& JONE-

Sitinese Mall, Nore York

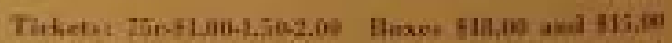
$\mathrm{W}=\mathrm{Tus}, \mathrm{li}$ per-erur atifitional Qil Gile at Hes ofive 
Program \#17: Recital at Carnegie Hall in New York, Oct. 31

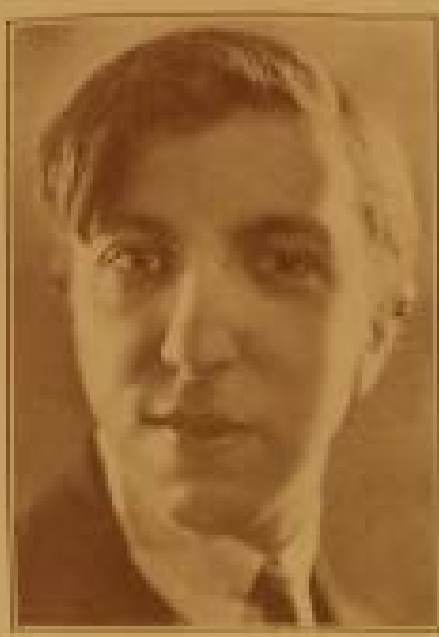

\section{CARNEGIE HALL \\ 5ith 5T, \& A AVE NEW YORK CTY}

\section{Wednesday Evening \\ OC T O B E 31 \\ at 3:15 a'cloce}

\section{MIECZYSLAW}
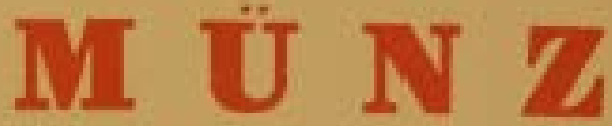

TIA NIST

| |rogrant:

Toceata and Fague C major . Bach-Busoni

$\mathbf{u}$

24 Preludt:, 0 pu- 28

Cisตin

III

2 Lepread-

St. Francis Preaching to the Birds

St, Francis Walking on the Waves f

IV

Naila

Dohnanyi-Defilieg

KNATE DIAWO ESTO

INPSCO NECONAS

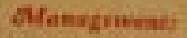

HAENSEL \& JONES

Arndian Hall, Ner Yarb

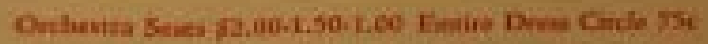

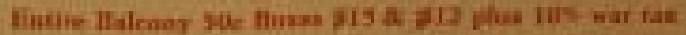
Qu fisle ar hax Otfics. 
Program \#18: Selected cover page among five concerts at Town Hall, Adelaide, Australia in 1924

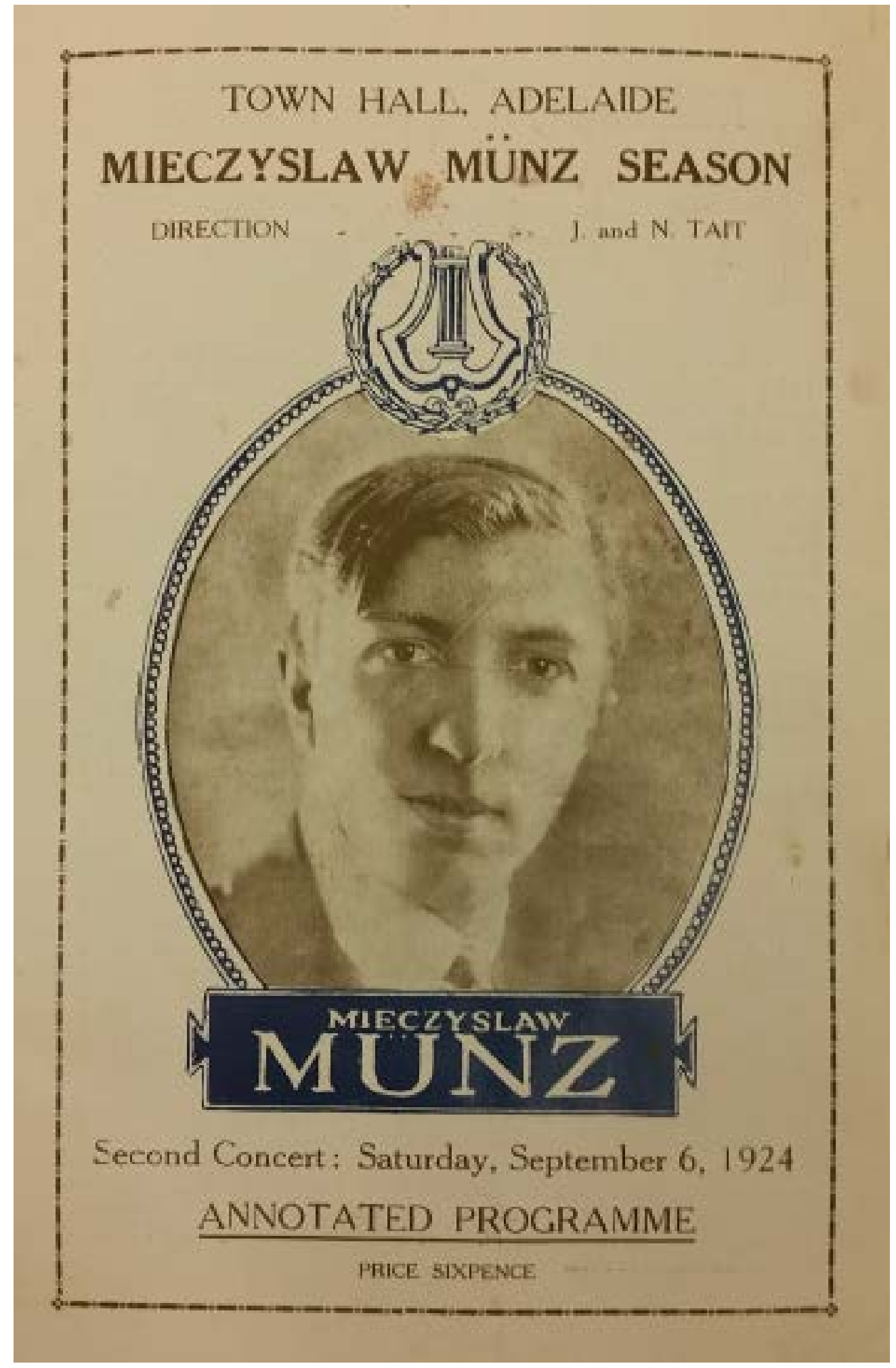


Program \#19: Program of Second Concert of the season at Town Hall, Adelaide, Australia in 1924

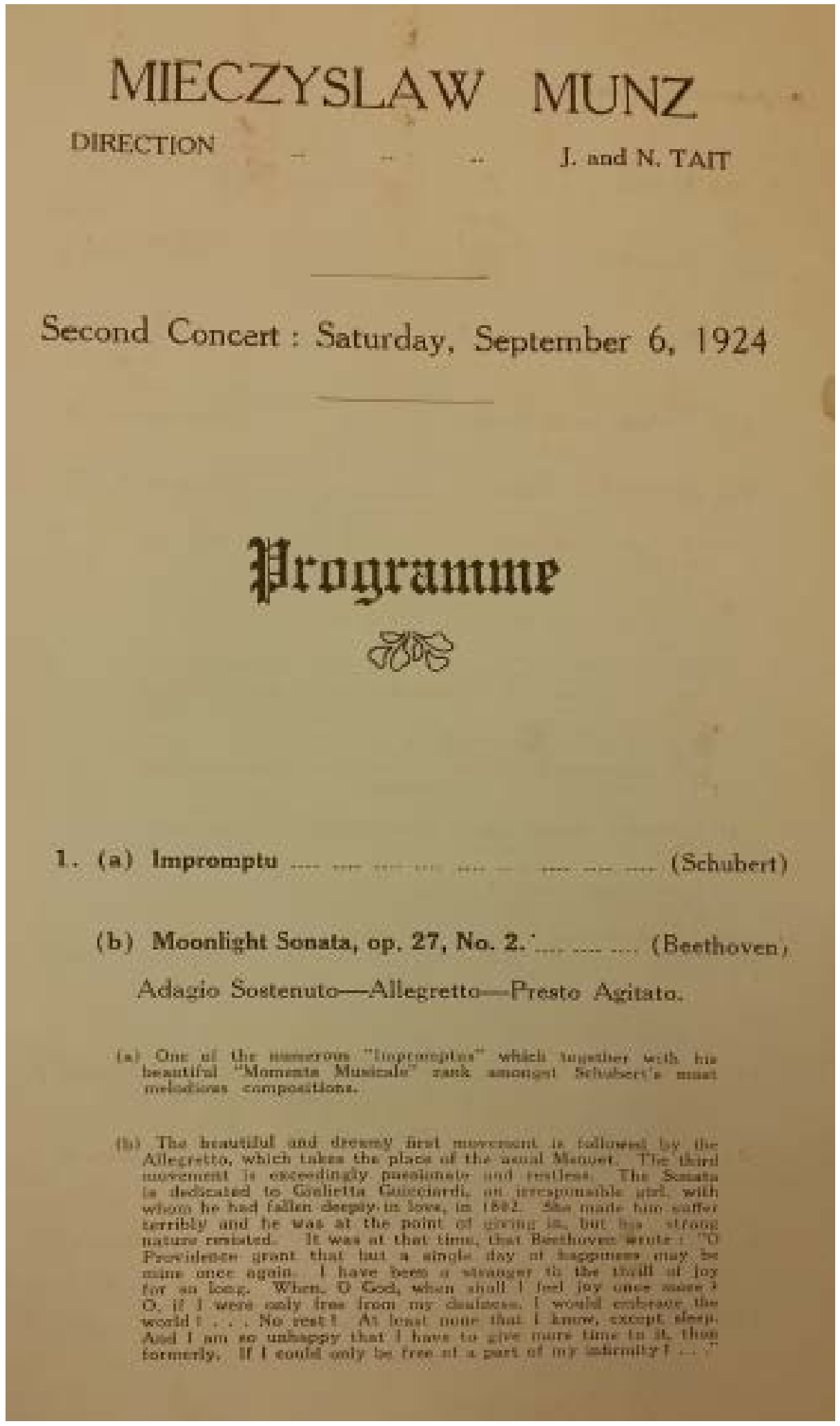




\section{Program \#20: continued}

\section{Programme Continued}

11. (a) Melody (Clack-Sgambiati)

(b) Gavotte (Glurk-Brahms)

(c) Rhapsody in G Minor (Brahms)

(d) Prelude in G Sharp (Rachmaninoff)

(c) Prelude in G Minor (Rachmaninoff)

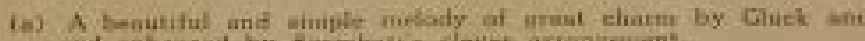

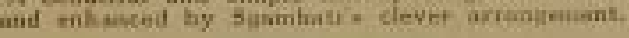

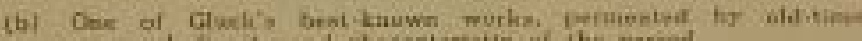

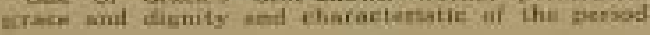

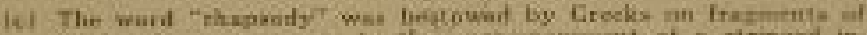

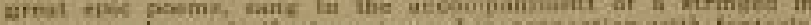

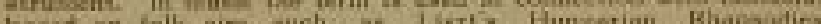

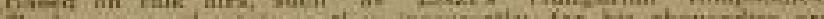

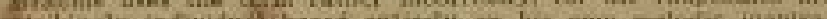

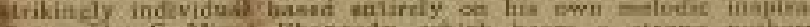

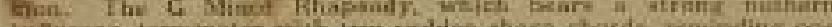

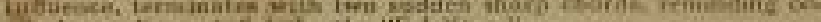
ail the entilitg of Schnhert', "F.ri-Xiag.

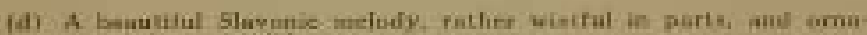
ineoted by gracetul panamase

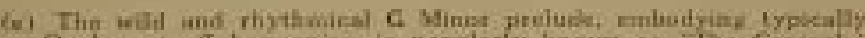
Aschmanims ff hambonics, is populorly known of th- Cosiack.

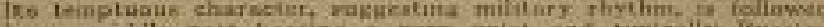

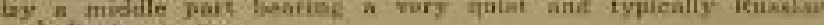
forlodie inopiratoon,

111. (a) Nocturne in F Minor, op. 55, No, 1. (Chopin)

(b) Mazourka in F Minor (Chopin)

(c) Mazourka in A Minor, op. 67, No. 4 (Chopin)

(d) Valse in C Sharp Minor, op. 64, No. 2 (Chopin) 


\section{Program \#21: continued}

Progrimmel Continued

(e) Etade in C Minor, op. 10, No, $12 . \ldots$ (Chopin) (Revolutionary)

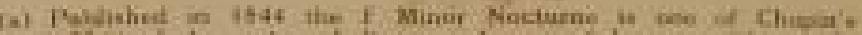
akAjet, bet most melodient wot nourntul compoesions, the

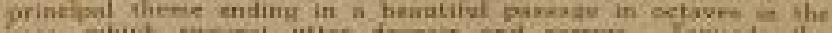

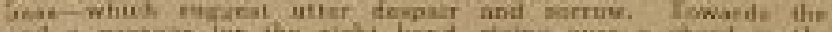

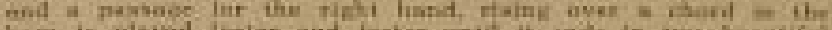

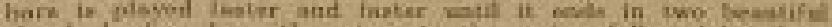

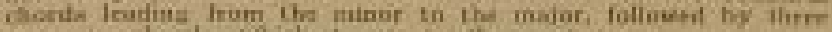
orpausin ehords, which tarmanase the nocturne.

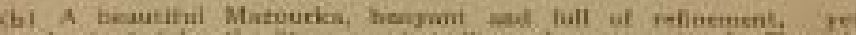

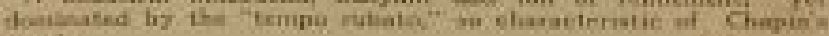
mukie

$$
\text { in's }
$$

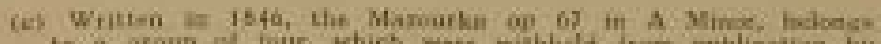

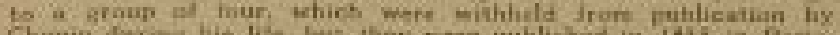

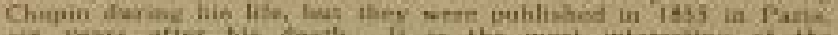

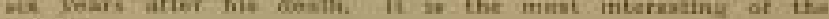
istrail.

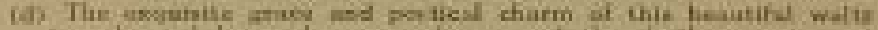

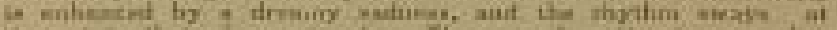

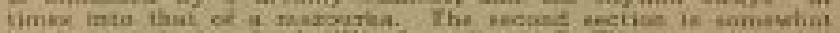

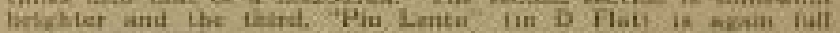

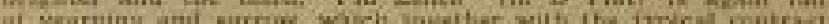

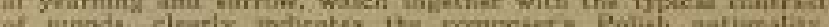

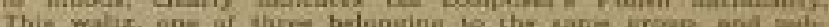

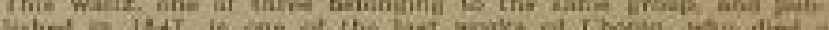

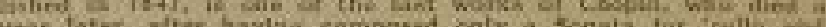

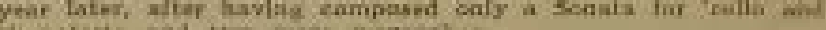

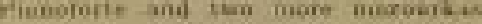

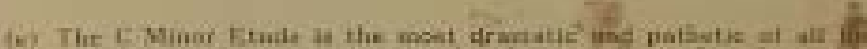

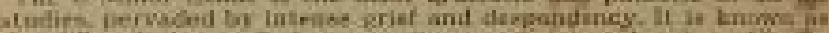

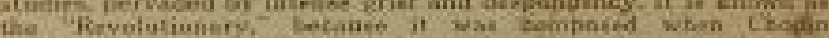

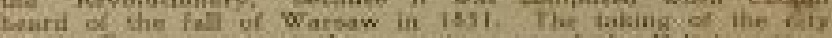

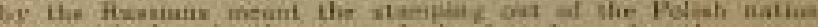

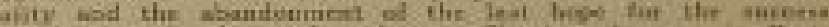

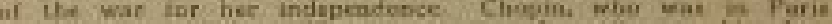
at the tline whe terribly oporet mut only ening to lis decp

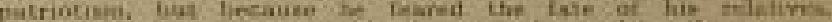

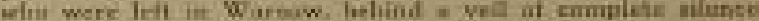

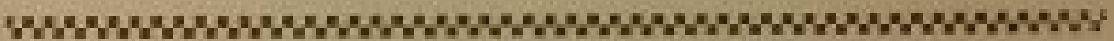

THE YOUNG POLISH GENIUS CF: THE PLANO.

\section{MIECZYSLAW MUNZ}

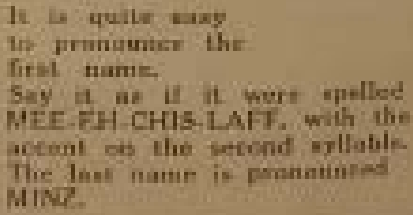


Program \#22: Cover page of Grand Piano Recitals (five days in a row except Monday with different programs) at Imperial Theatre in Japan, 1924

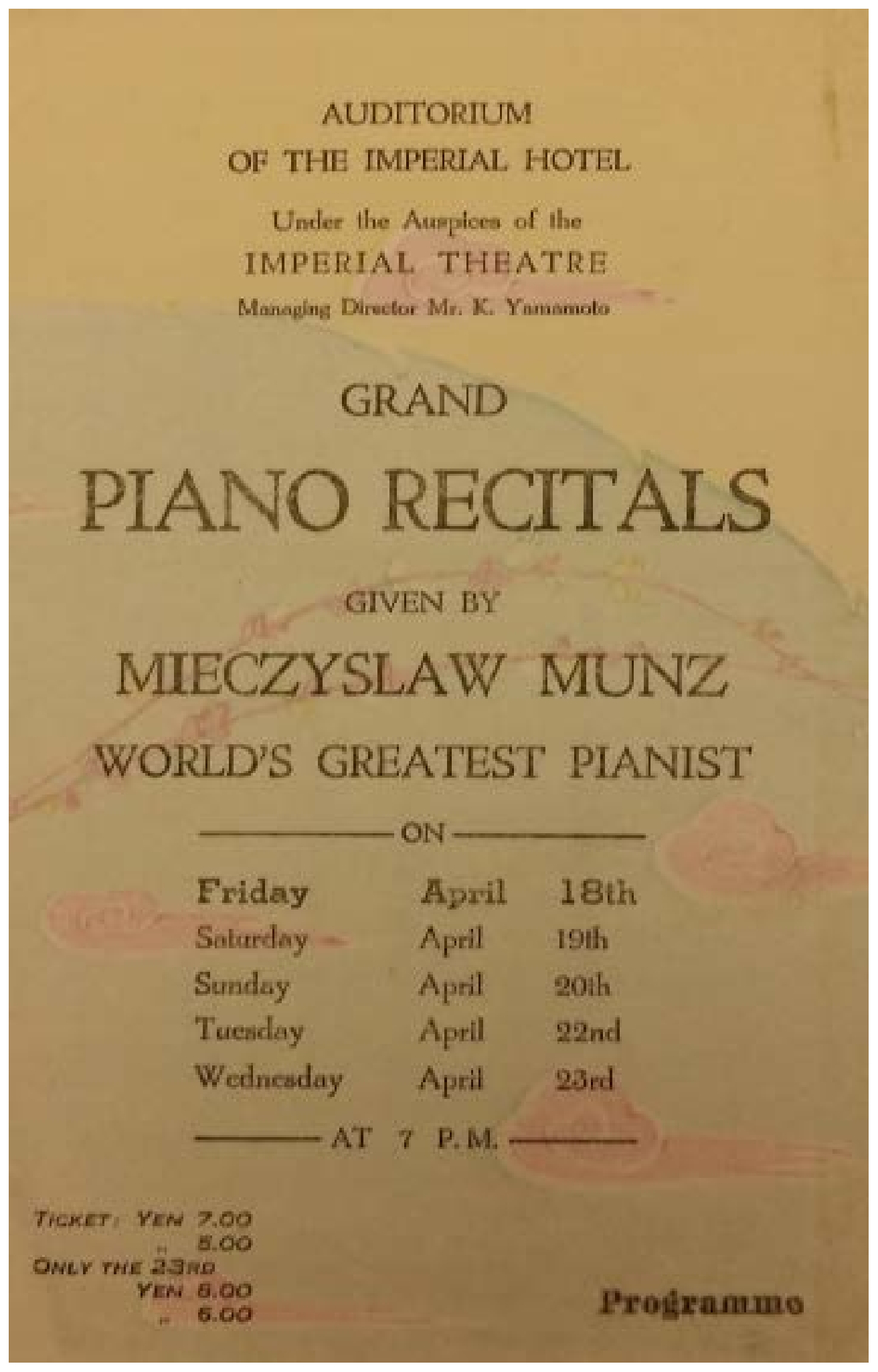


Program \#23: Program no. 1, $18^{\text {th }}$, April

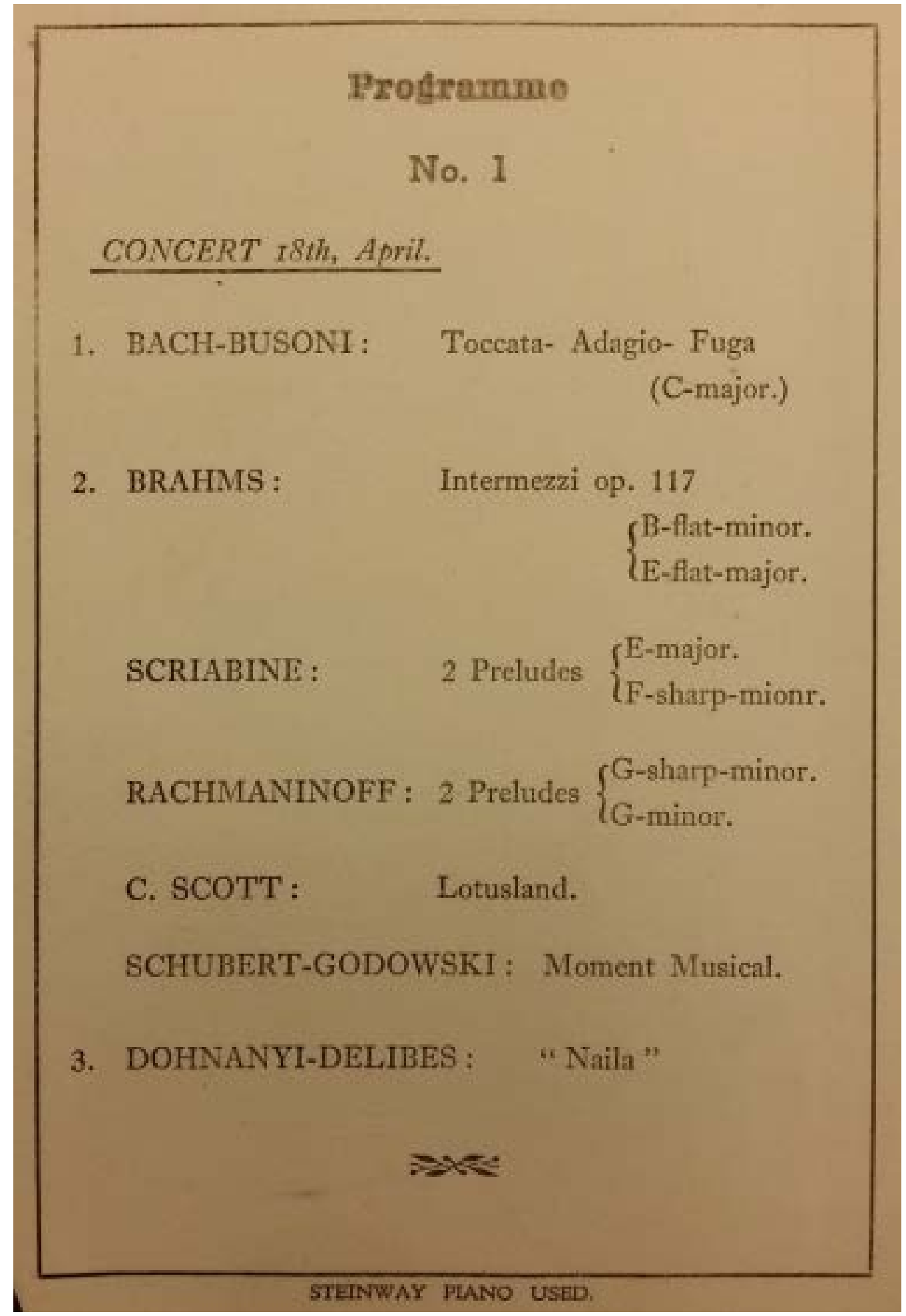


Program \#24: Program no.2, $19^{\text {th }}$ April

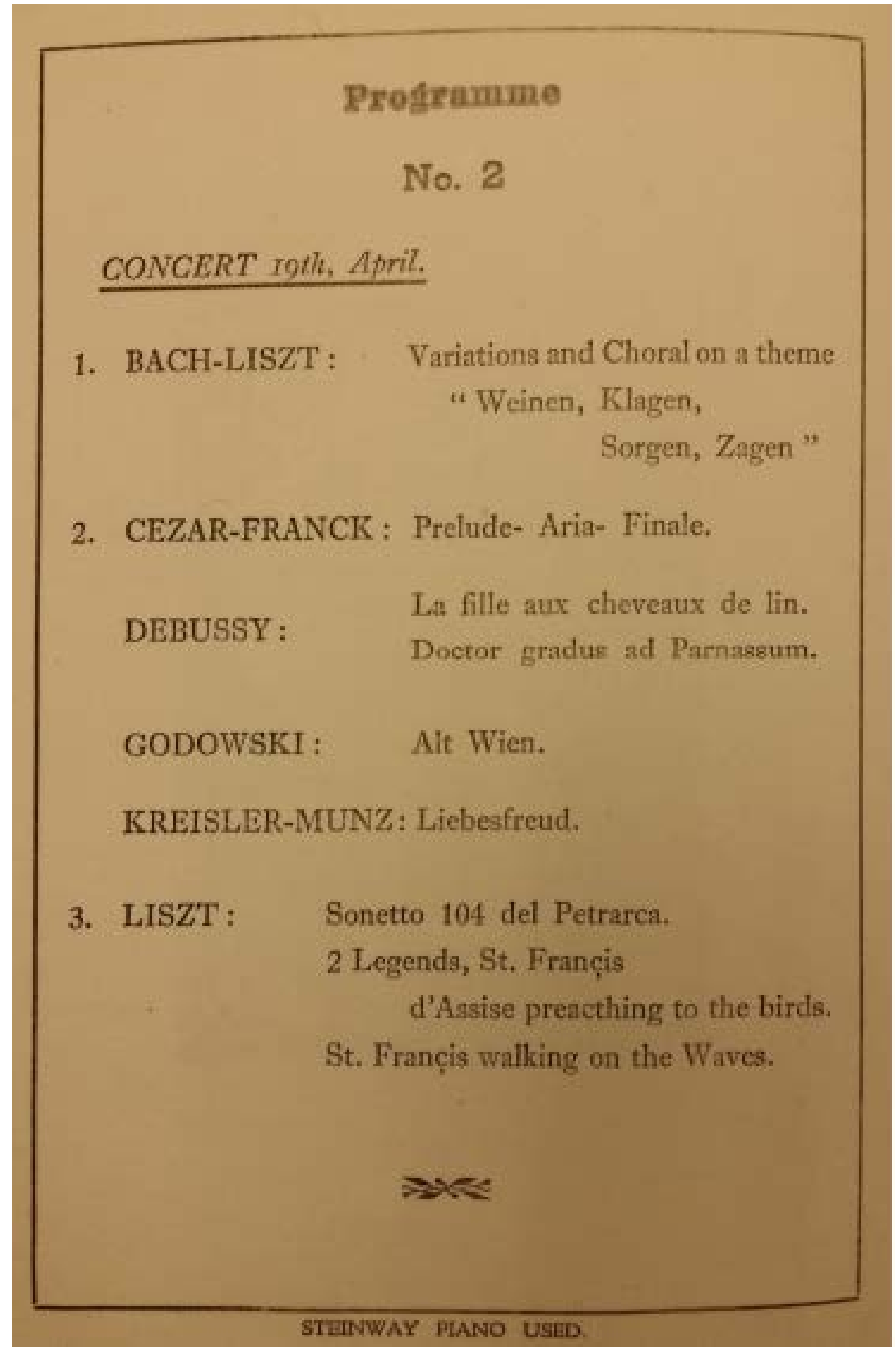


Program \#25: Program no.3, 20 ${ }^{\text {th }}$ April

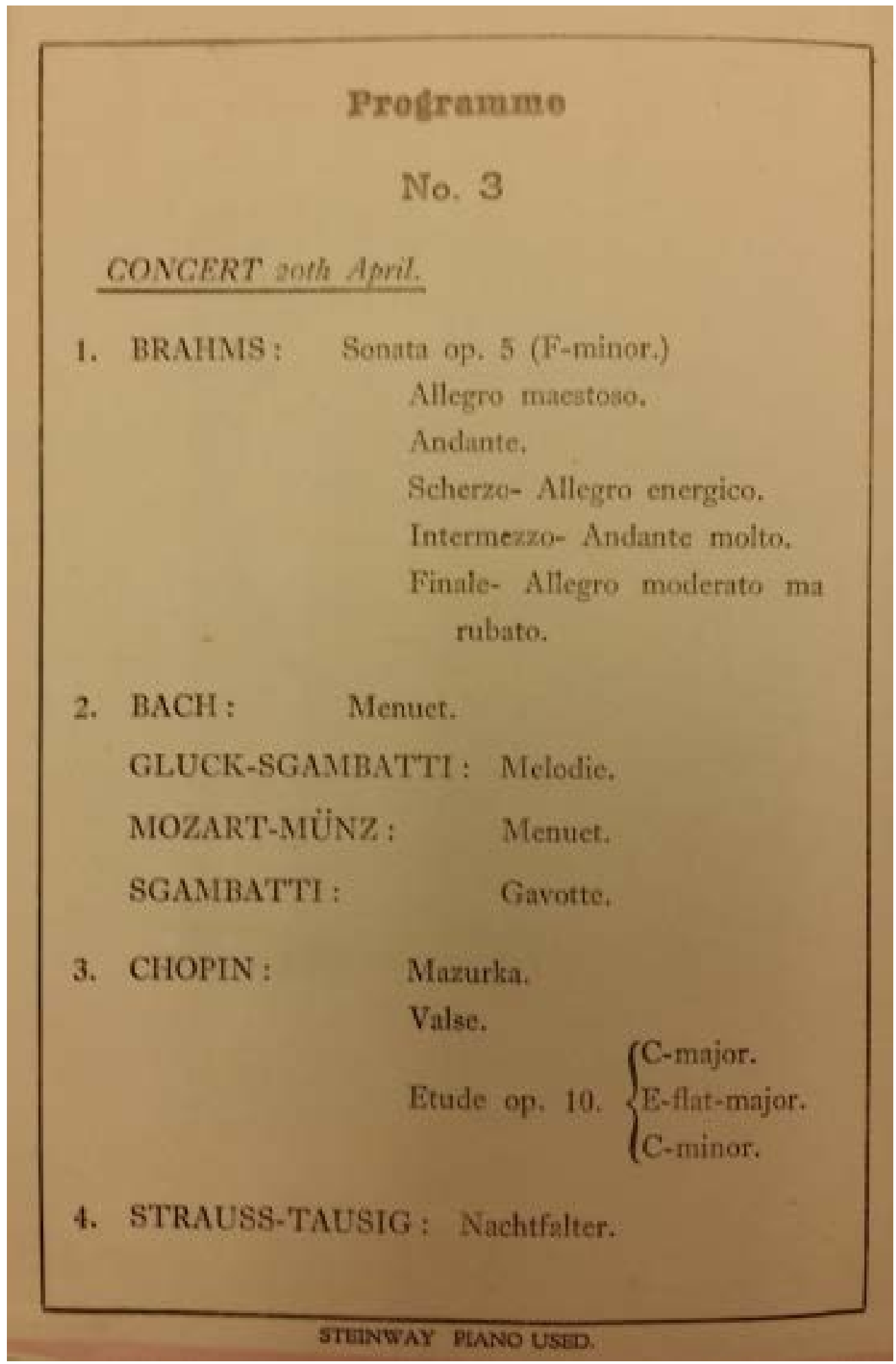


Program \#26: Program no. 5 (no. 4 was missing) $23^{\text {rd }}$ April

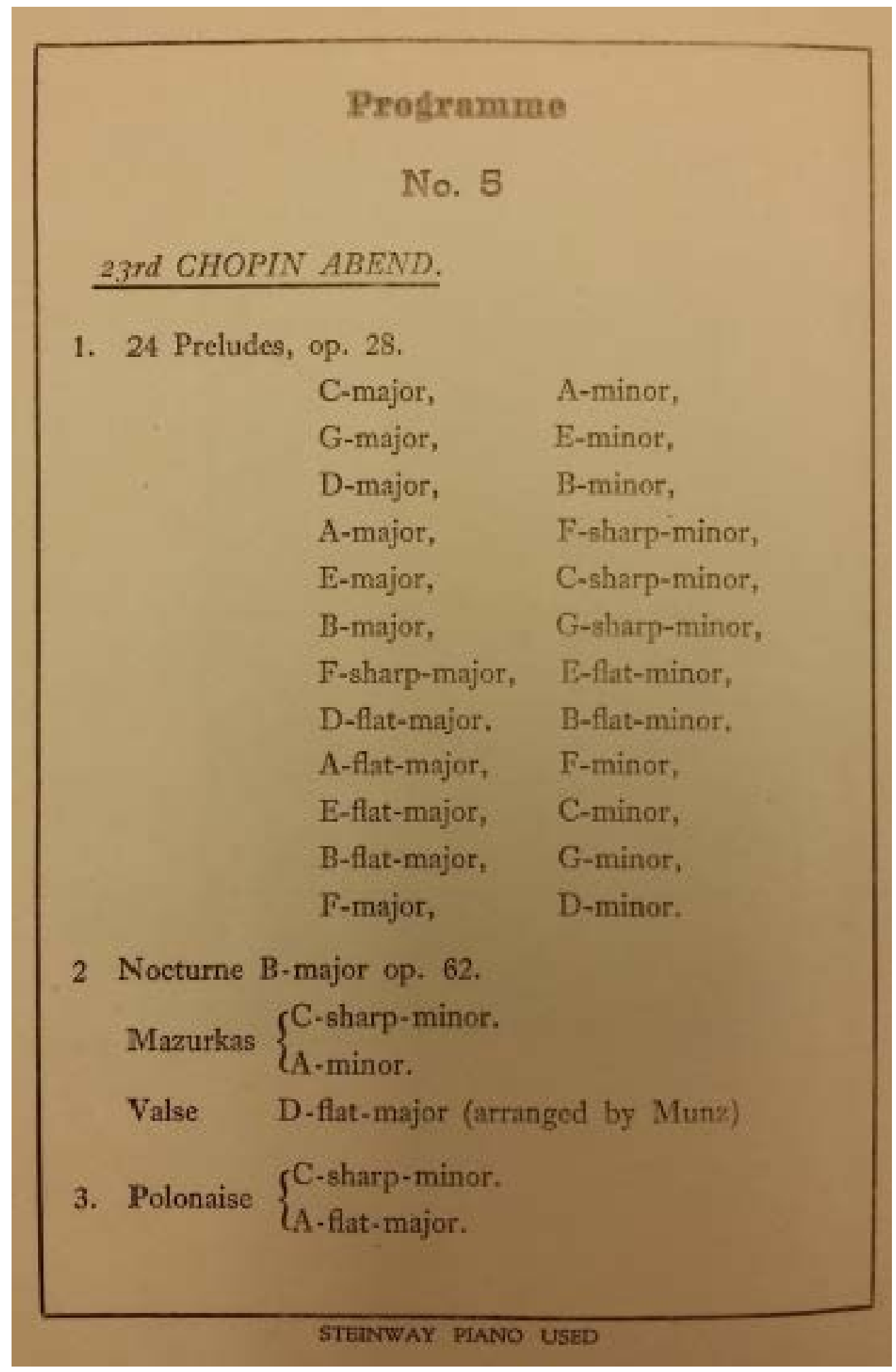


Program \#27: Recital at Krakow in Poland, 1926

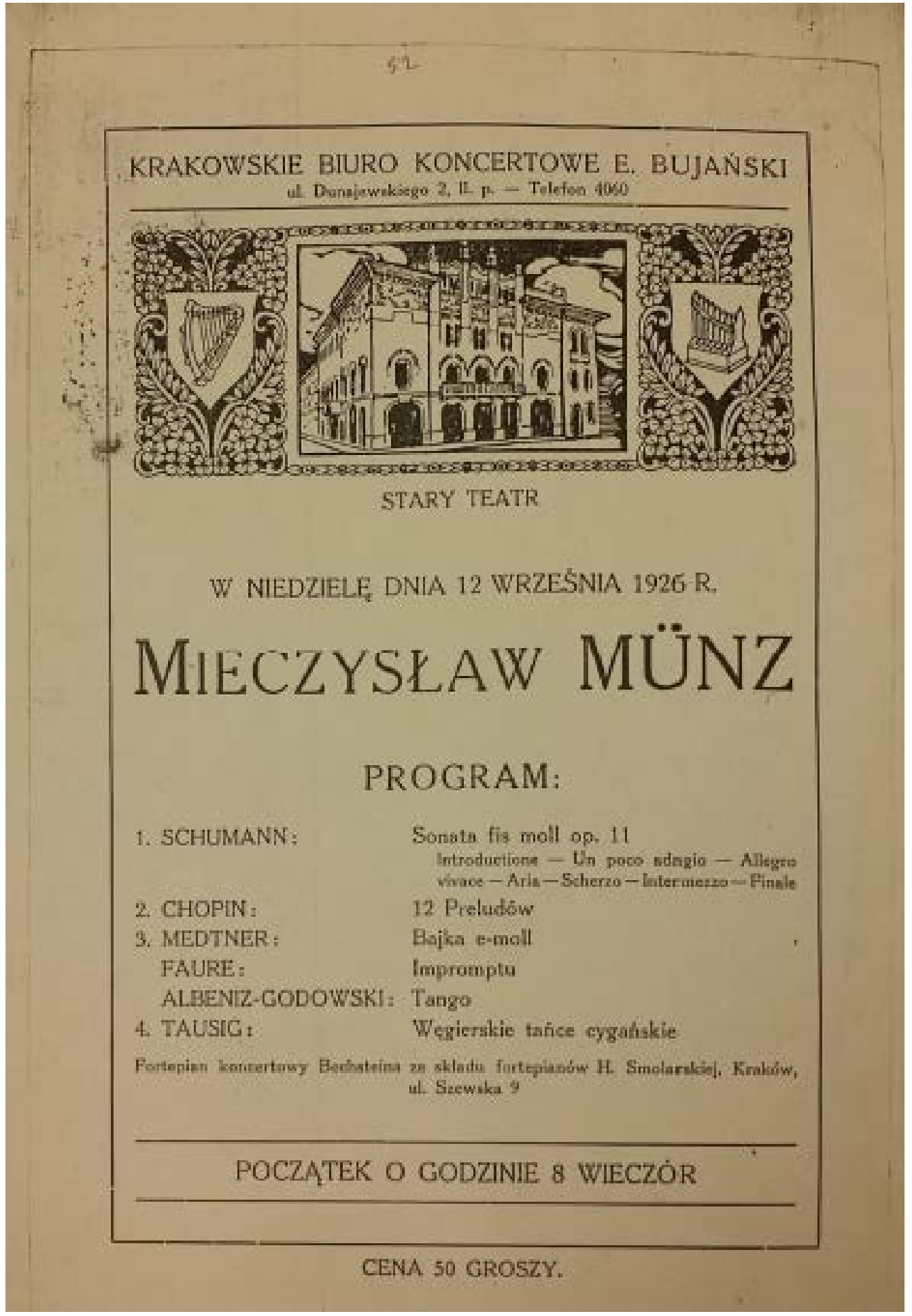


Program \#28: Cover page of recital with The New York String Quartet in Germantown, Maryland in 1929

$$
\frac{\text { Program }}{\sqrt{2} s}
$$

\title{
The New York String Quartet
}

\author{
UNDER THE AUSPCES OF
}

Germantown Community Concert Association

\section{GERMANTOWN HIOH SCHOOL}

NOVEMHER 2tat, 199 
Program \#29: Program of recital with The New York String Quartet in Germantown, Maryland in 1929

\section{I}

Quartet in F Major (The American Quartet) . Dvorak

Allegro ma non troppo

Lento

Vivace ma non troppo

THE NEW YORK STRING QUARTET

II

Prfilude in G Major . . . . . . . . . . Rachmaninoff

Prilude in D Flat Major. . . . . . . . Liadow

Der Müller und der Bach + . . . . . Schubert-Lisxt

SOIRÉ dI VIENNe . . . . . . . . . . . Schubert-Liszt

MR. MUNZ

III

Quistet in E Flat Majon, Orva 14 . . . . Sehumann

Allegro brilliante

In modo d'una marcia

Scherzo molto vivace

Allegro ma non troppo

MR. MUNZ, AND THE NHW VORK STRING QUARTET

Baldwin Piano Duo Art Records

The New York String Quartet records for Brunswick

Managament for Mr. Münz: Haensel \& Jones, Steinway Hall, New York.

Management for The New York String Quartet: Concert Management Arthur Judson, Inc., Steinway Hall, New York. 
Program \#30: Cover page of the Recital at Buenos Aires, Argentina in 1932

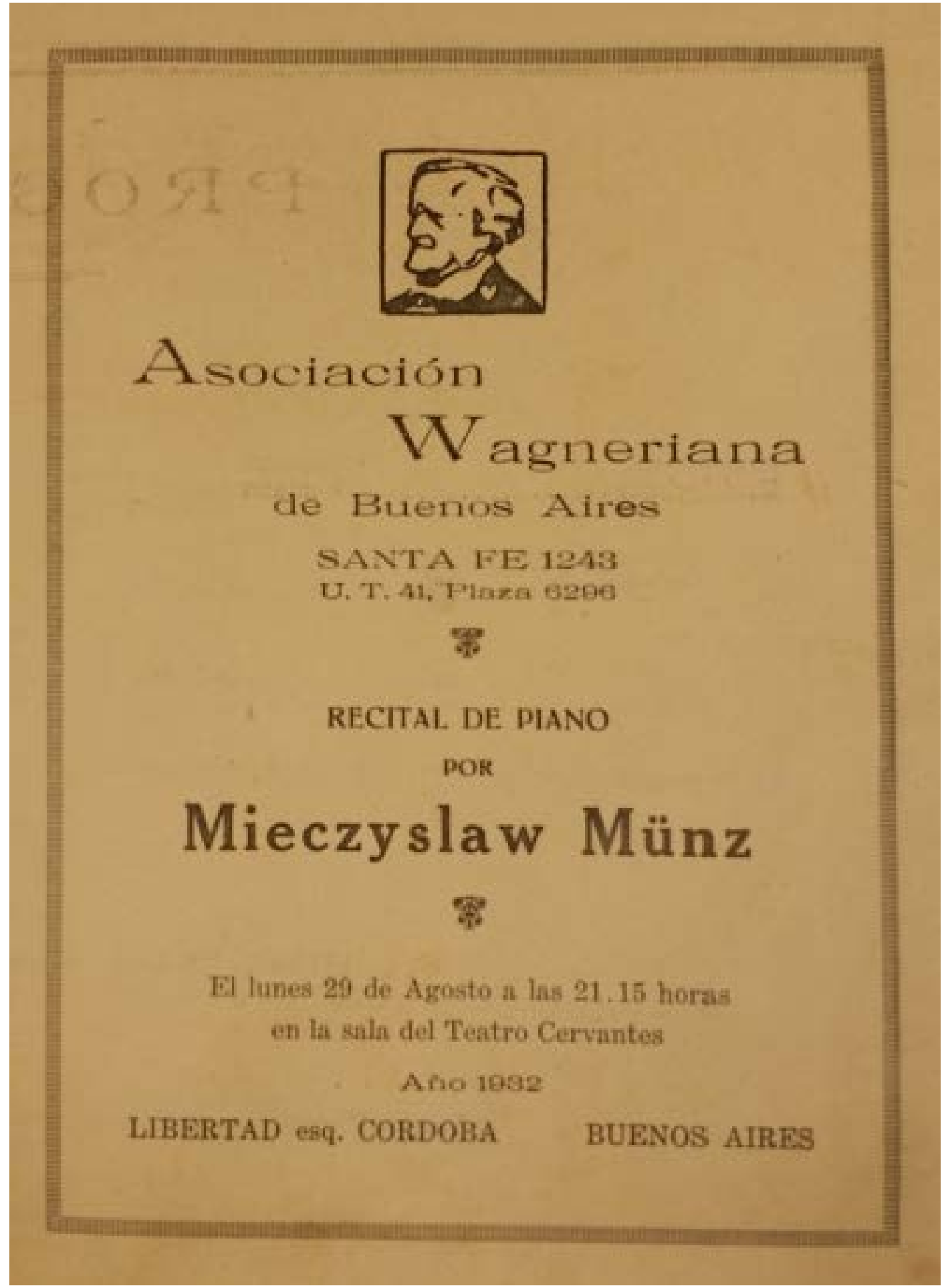


Program \#31: Program of the Recital at Buenos Aires, Argentina in 1932

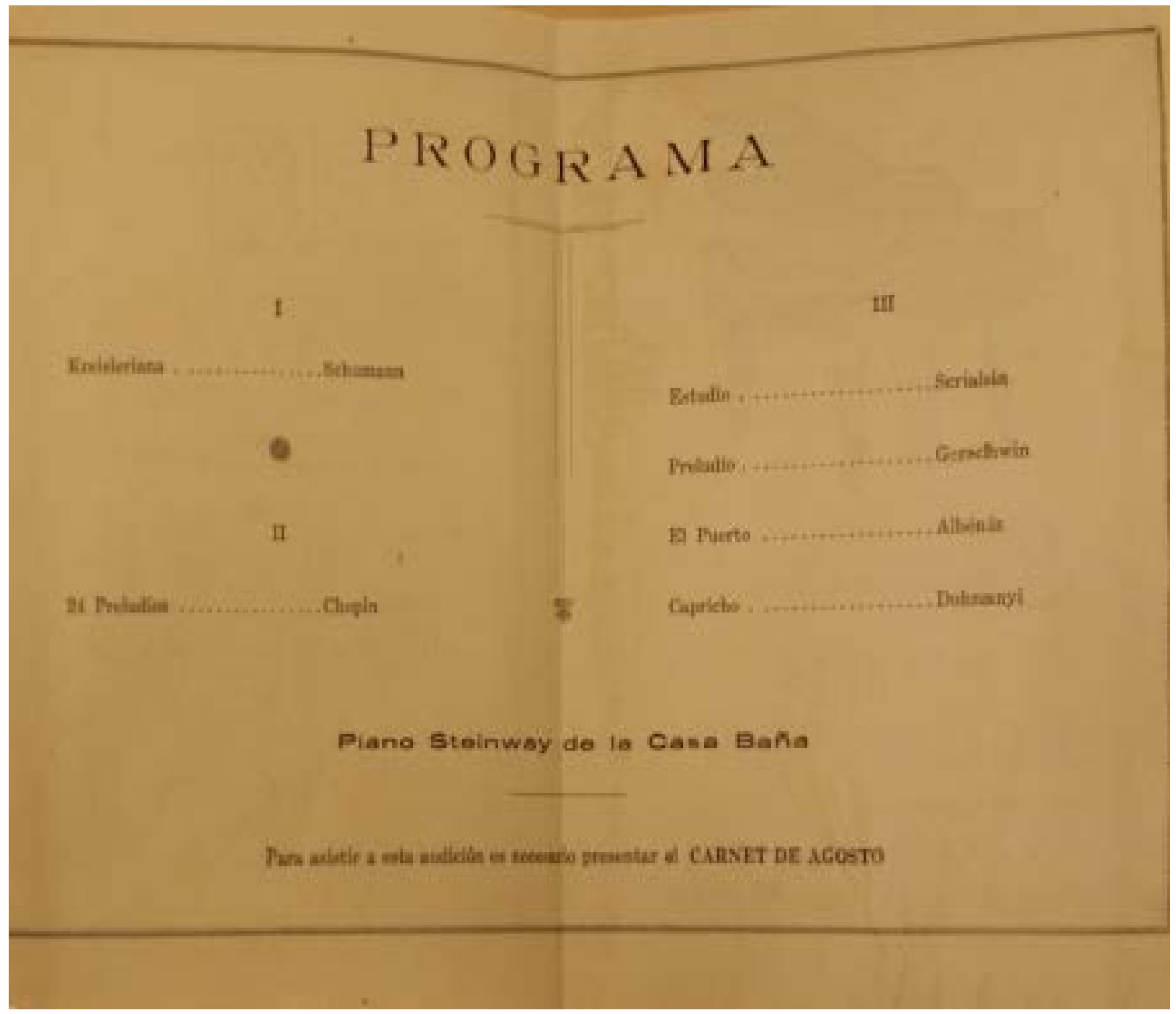


Program \#32: Concert with Waco Symphony Orchestra at Waco, Texas in 1940

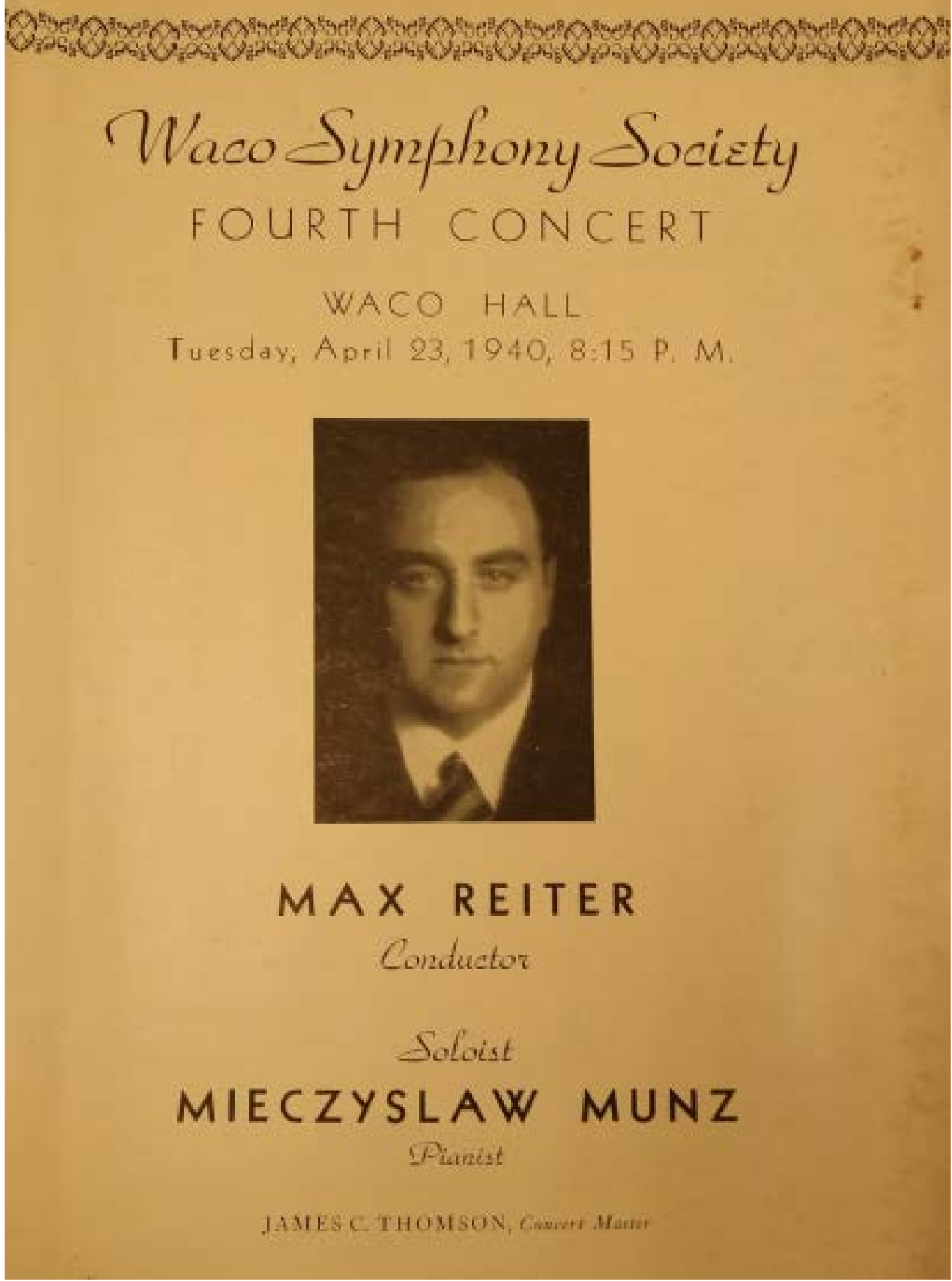


Program \#33: Solo Recital at Independence Theatre in Mexico. (year is unknown)

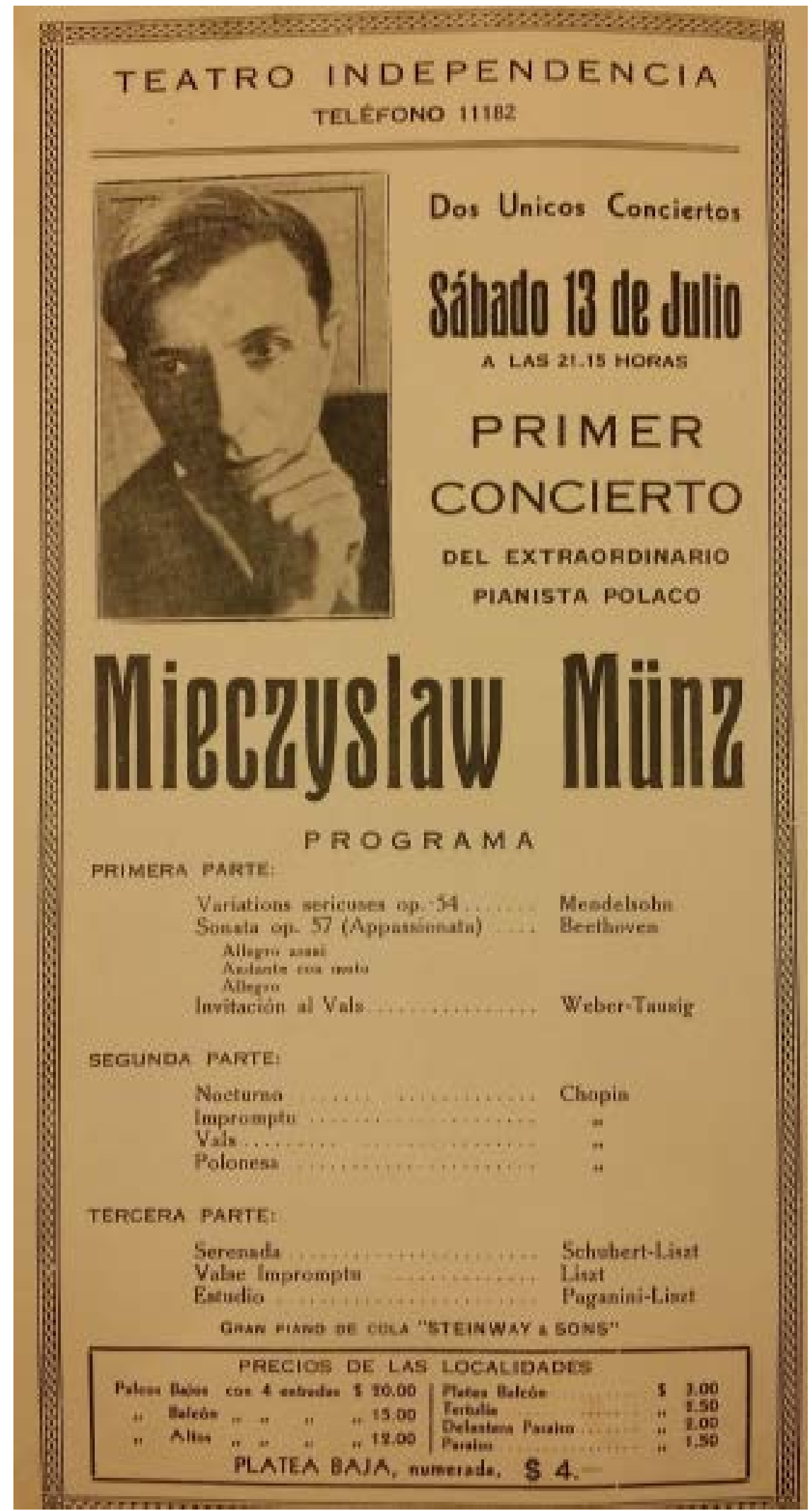


Program \#34: Concert with Minneapolis Symphony Orchestra at Woodland Auditorium in Arizona (year is unknown)

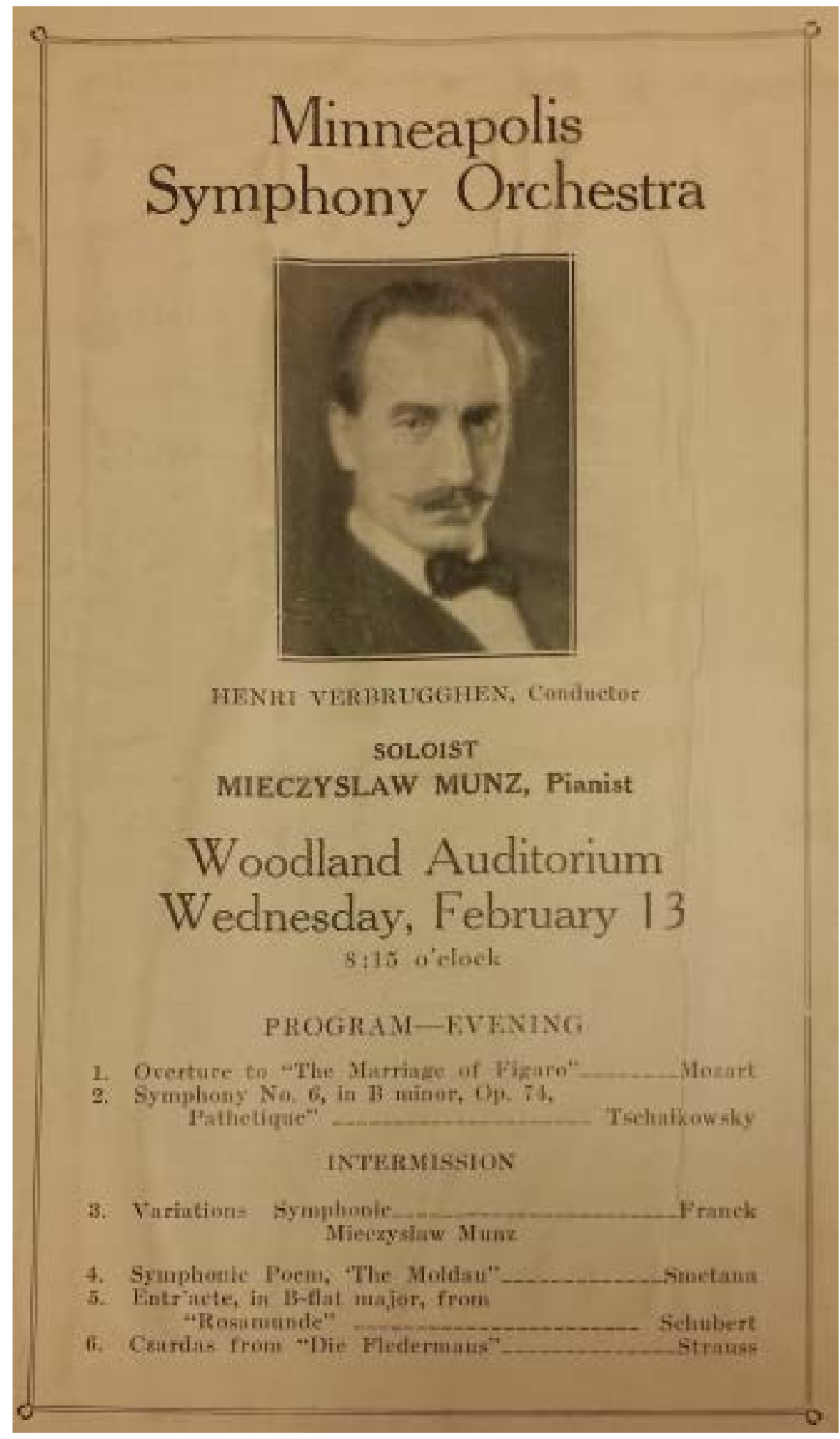


APPENDIX C

Selected Photos

Photo \#1: Young Mieczyslaw Munz

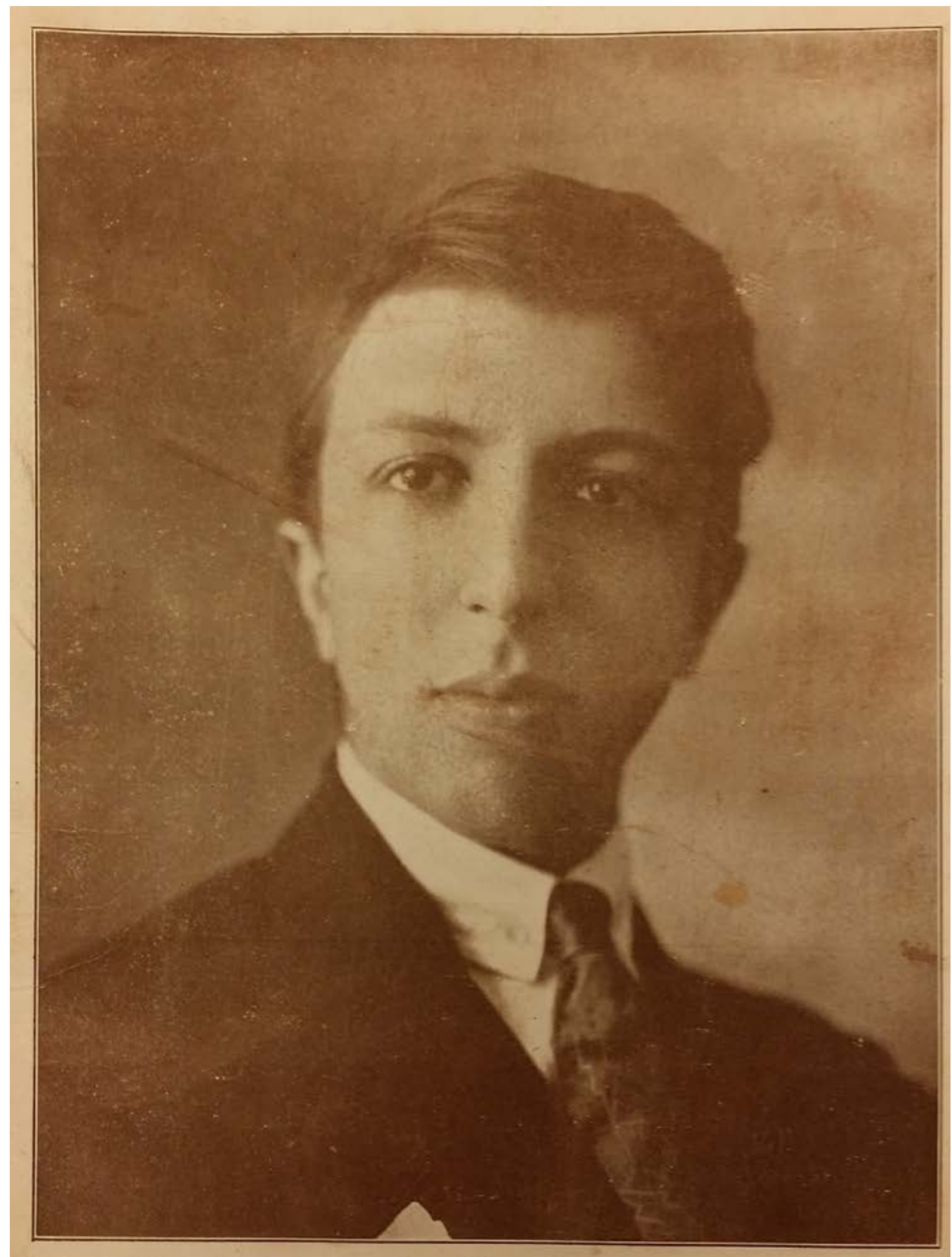


Photo \#2: From program note

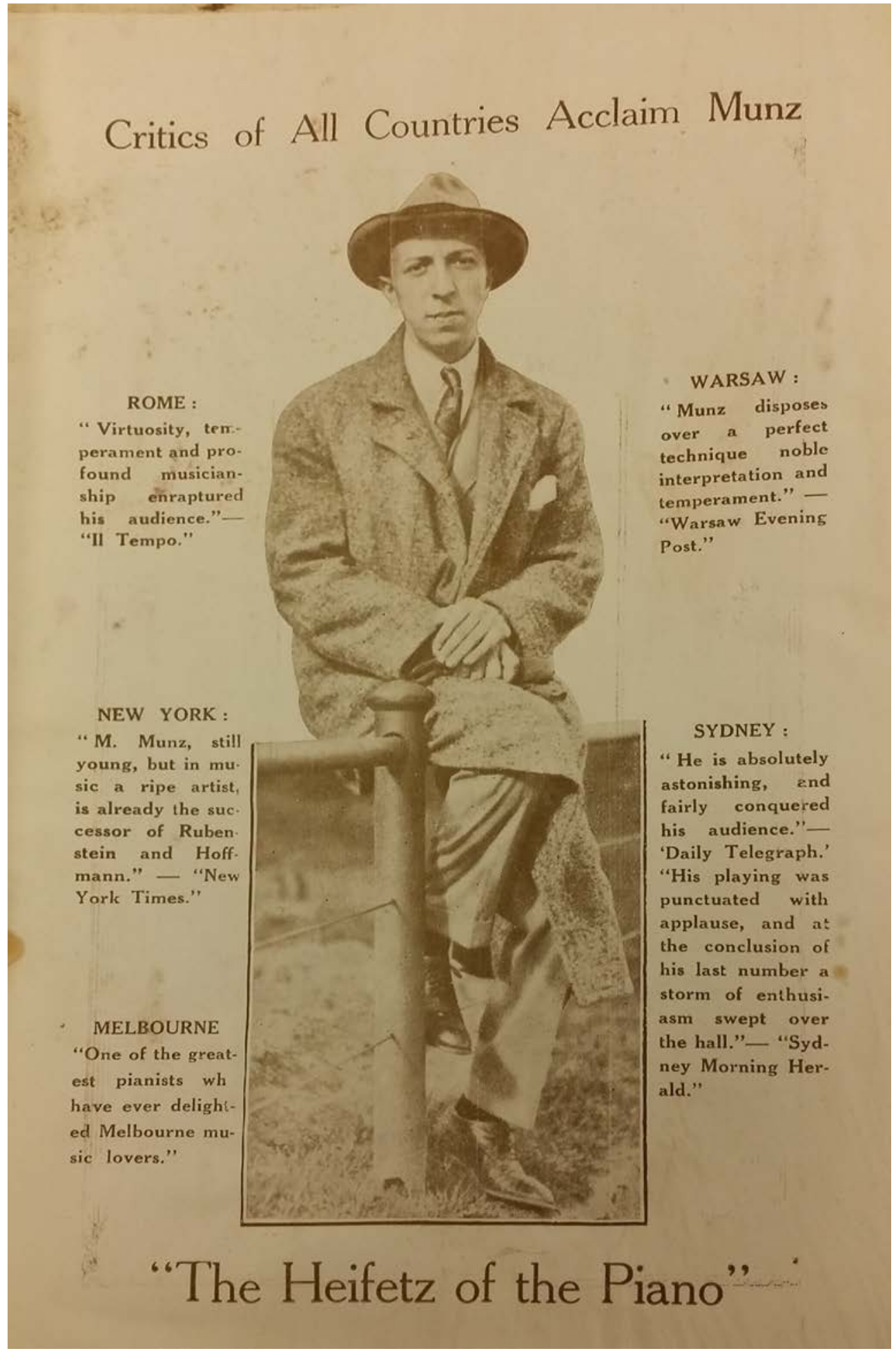


Photo \#3: Screen shot from youtube

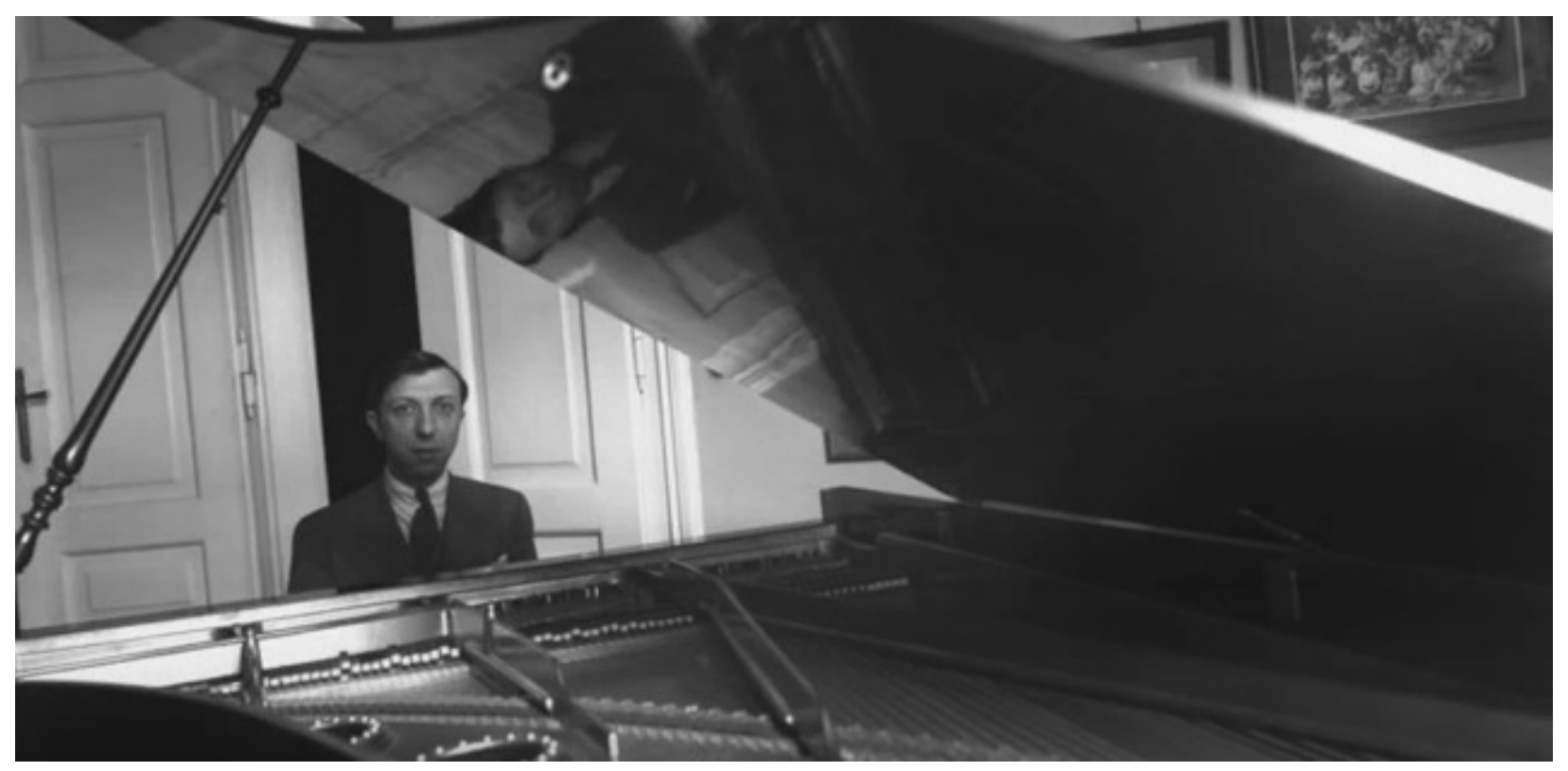


Photo \#4: Advertisement

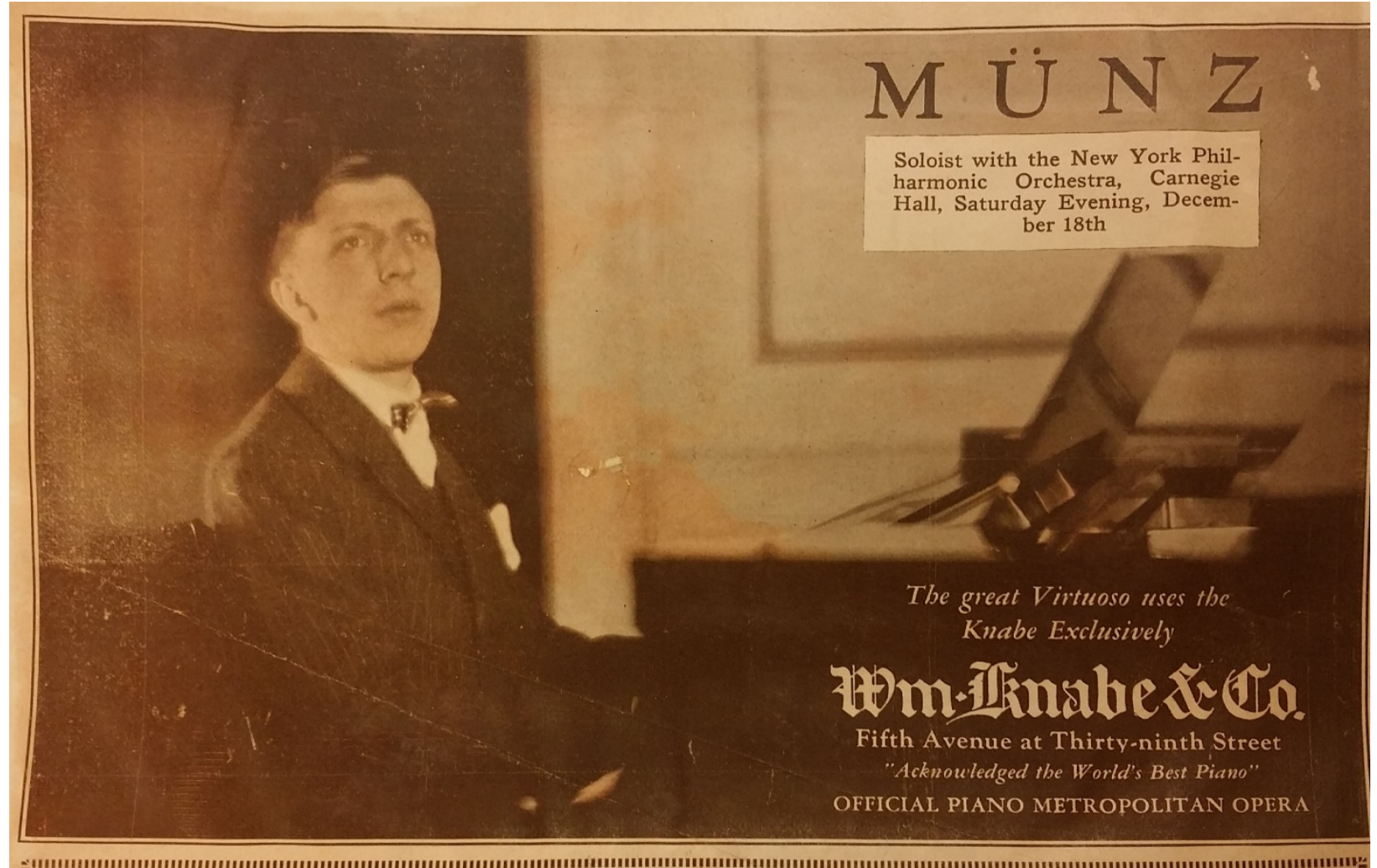

2 
Photo \#5: At the live recital

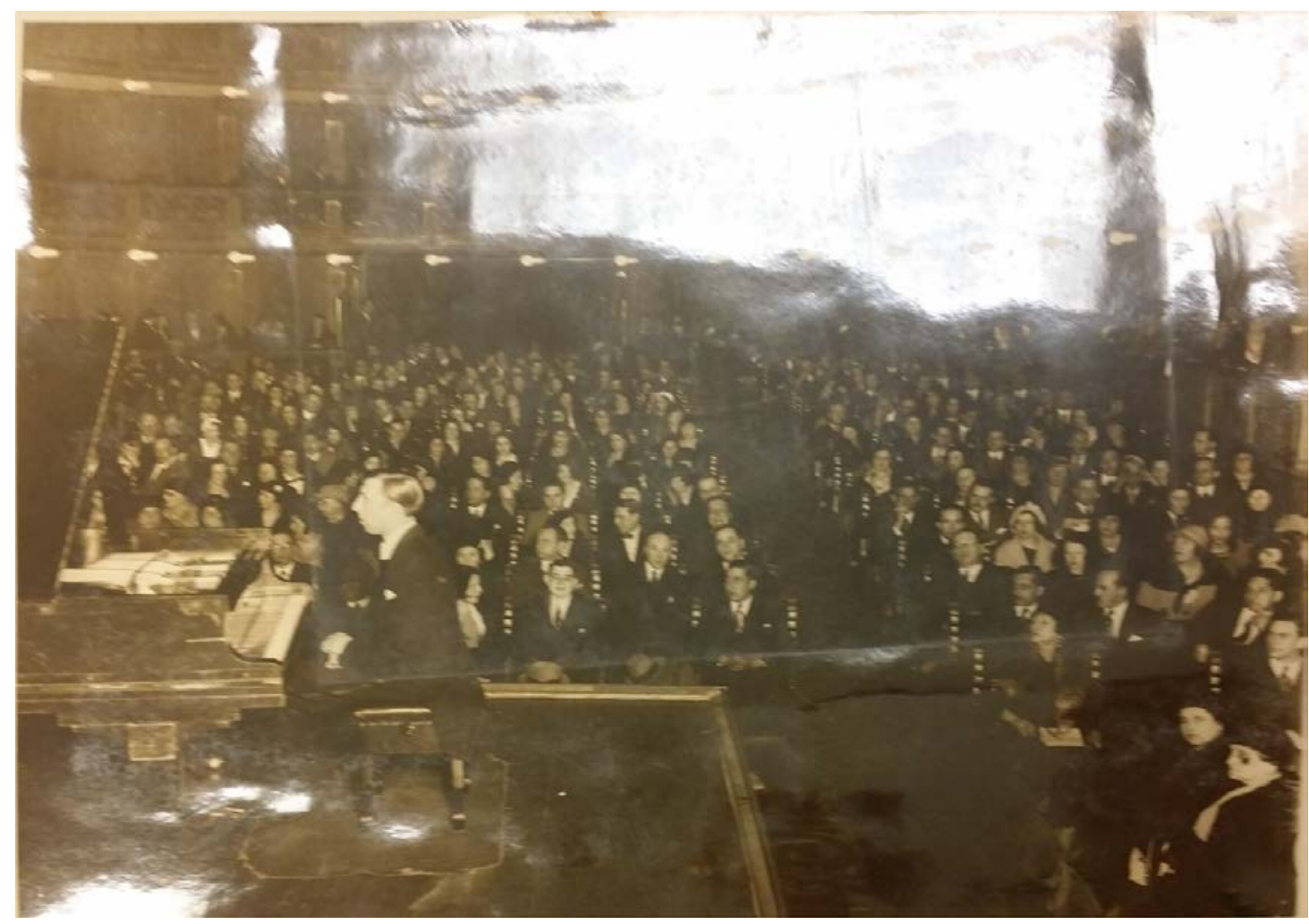


Photo \#6: Taken from Toho Music School in Japan

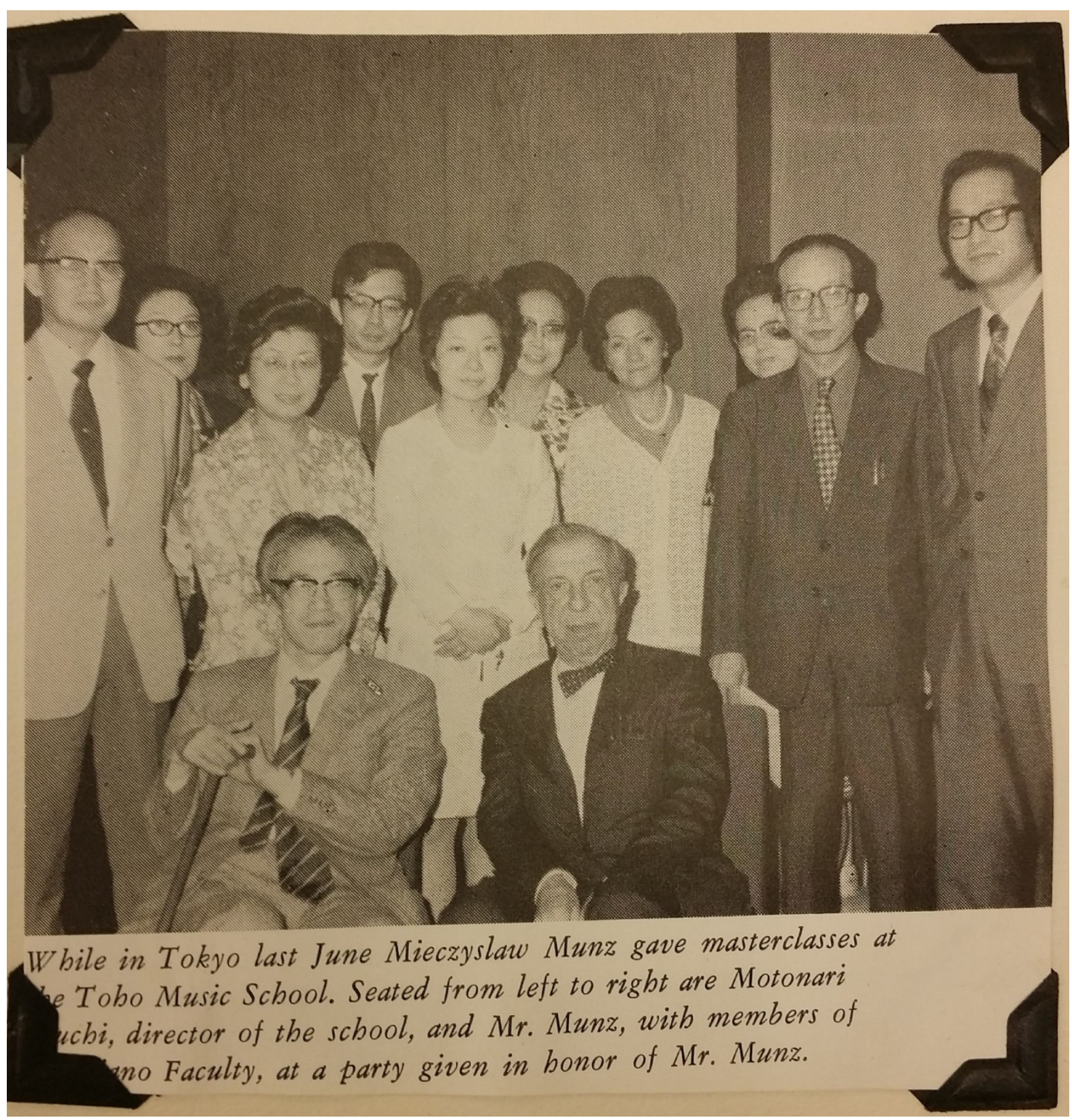




\title{
APPENDIX D
}

\section{Recordings by Mieczyslaw Munz}

\author{
Ampico Rolls \\ *Chopin: Etude Op.10 No. 12 (“Revolutionary”) \\ Chopin: Preludes Op.28 Nos. 1, 3, 8, 16-19, 21-24 \\ Fauré: Impromptu, Op.31 \\ Schubert-Godowsky: Rosamunde Ballet Music \\ Liszt: Paganini Etude No.2 \\ Sgambati: Gavotte, Op.14 \\ **Strauss-Tausig: Nachfelter, Op. 157 \\ Dohnanyi-Delibes: “Naila”
}

*Reissued on “Ampico Rolls in the $21^{\text {st }}$ Century: Chopin Etudes and Nocturnes,” The CEUS Project CD Series, (eleced - paa-009), 2007/2010

**Reissued on "Ampico Rolls in the $21^{\text {st }}$ Century: Recital Hall: Encores and Recital Items Performed by Legendary Pianists of the Past,” The CEUS Project CD Series, (eleced - paa-002), $2007 / 2010$

\section{Art of Mieczyslaw Munz - CD}

Original Release date: April 9, 2002

Americus Records, Inc.

Mozart: Piano Concerto in D Minor with NBC Symphony Orchestra under Conductor Frank Black (Live)

Sgambati: Gavotte, Op.14

Schubert-Godowsky: Ballet Music from "Rosamunde”

Chopin: Etude in E-Flat Major 
Faure: Impromptu in A-Flat Major, Op.31

Chopin: Six Preludes from Op. 28, Nos. 1-6

Ravel-Ericourt: Pièce en forme de Habanera

Scriabin: Etude in C-Sharp Minor, op.2

Dohnányi: Coppélia

Rachmaninoff: Rhapsody on a Theme of Paganini with National Orchestral Association under Conductor Leon Barzin (Live) 


\section{BIBLIOGRAPHY}

Ax, Emanuel and Ann Schein. "Remembering Mieczyslaw Münz with Emanuel Ax and Ann Schein” Virtuoso 1, no. 71 (1980): 14-16.

Ainley, Mark. "Magnificent Münz” The Piano Files” http://www.thepianofiles.com/?s=Mieczyslaw+Münz (accessed February 22, 2016)

Belanger, J. Richard. “Wictor Labunski: Polish-American Musician in Kansas City, 1937-1974: Case of Study.” Ph.D. diss., Columbus University Teachers College, 1982.

Brochure from The Mieczyslaw Munz Scholarship Fund, Inc.

Dubal, David. The Art of the Piano: Its Performance, Literature, and Recordings. Hal Leonard Corporation, 2004.

Ford, M. Emmett. “Biographical Sketches: Mieczyslaw Munz” AMICA 14, no. 3 (April, 1977):72-73.

Hautzig, Walter. “To the Editor” Keyboard Companion 18, no. 2 (Summer, 2007): 47.

International Piano Archives at University of Maryland. "Mieczyslaw Munz Collection” http://www.lib.umd.edu/ipam/collecions/mieczyslaw-munz (accessed November 16th)

Litzelman, James. “Ann Schein: Pupil, Performer, Teacher” American Music Teacher 64, no.3 (December 2014 - January 2015): 31-34.

Marcus, Jeffrey. Biography taken from http://www.jeffreymarcuspianist.com/biography/index.html (accessed March 4, 2016).

Mieczyslaw, Munz. Letters to Mary Louise Curtis Bok, 1933 - 1943. Collection from Curtis Institute.

Mieczyslaw, Munz. Collection of Munz’s Personal Files. Archives of University of Cincinnati, CCM. 
Minakowski, M.J. Family Tree of Aniela Mlynarski http://www.sejm-wielki.pl/psb.18596.11 (accessed February 28, 2016).

Mookerjee, Rosemary. “Mieczyslaw Munz: His Students and His Teaching” M.M. Thesis, The Catholic University of America, 1987.

Oei, David. Biography taken from http://davidoei.weebly.com (accessed February 6, 2016).

Oron, Aryeh. “Short Biography: Wiktor Labunski (composer, arranger)” Bach Cantatas Website, http://www.bach-cantatas.com/Lib/Labunski-Victor.htm (accessed March 8, 2016)

Oron, Aryeh. “Short Biography: Walter Hautzig (piano)” Bach Cantatas Website http://www.bach-cantatas.com/Bio/Hautzig-Walter.htm (accessed March 4, 2016)

Quoted in “Program notes” of Mieczyslaw Munz Season at Town Hall. Melbourne, 1924.

Review of concert performance by Mieczyslaw Münz, Aeolian Hall, New York in October 20, 1922, New York Journal, October 21, 1922.

Review of concert performance by Mieczyslaw Münz, Aeolian Hall, New York in October 20, 1922, New York Tribune, October 21, 1922.

Review of concert performance by Mieczuslaw Münz, Aeolian Hall, New York in October 20, 1922, Musical Courier, November 23, 1922.

Rubinstein, Arthur. My Many Years. New York: Alfred A. Knopf, 1980.

Sachs, Harvey. Rubinstein: A Life. New York: Grove Press, 1995.

Saerchinger, Cesar. International Who's Who in Music and Musical Gazetteer: A Contemporary Biographical Dictionary. New York: Current Literature Publishing Company, 1918.

Saxon, Wolfgang. “Aniela Rubinstein, 93, Widow of Pianist and Patron of the Arts”, The New York Times, January 5, 2002.

Schein, Ann. "The Music of Chopin- my legacy from Mieczyslaw Munz and Arthur Rubinstein” Keyboard Companion 17, no.4 (December 2006): 38-41. 
Schein, Ann. Biography taken from http://annschein.com/biography (accessed February 19, 2016).

Stewart, Reginal. Biography taken from https://en.wikipedia.org/wiki/Reginald_Stewart_(conductor) (accessed March 10, 2016).

Swan, Robert. Biography taken from http://spu.edu/academics/college-of-artssciences/music/faculty-staff-directory/swan-robert (accessed March 4, 2016).

Taylor, Angela. “Nela Rubinstein: Making a Life of Her Own” The New York Times, December 12, 1983.

Todd, Andrew. KJAX-Aspen Public Radio: Interview with Ann Schein. https://www.youtube.com/v/zbmIk_fRIWo\&autoplay=1\&rel=0 (accessed February 24, 2016)

Young, Stefan. Biography taken from http://www.rider.edu/faculty/stefan-young (accessed March 10, 2016).

\section{Interviews}

Faye Bonner: $\quad$ February 12, 2016, in person at Potomac, Maryland

Paula Forrest: $\quad$ January 15, 2016, submitted written answers

Jeffrey Marcus: $\quad$ February 24, 2016, submitted written answers

David Oei: $\quad$ February 6, 2016, submitted written answers

Ann Schein: $\quad$ January 27, 2016, submitted written answers

Robert Swan: $\quad$ March 1, 2016, submitted written answers

Stefan Young: $\quad$ January 13, 2016, submitted written answers 